Werner Weiss I Irene Bergmann I Roman Stelzer

\title{
SOLAR HEAT WORLDWIDE
}

Markets and Contribution to the Energy Supply 2007
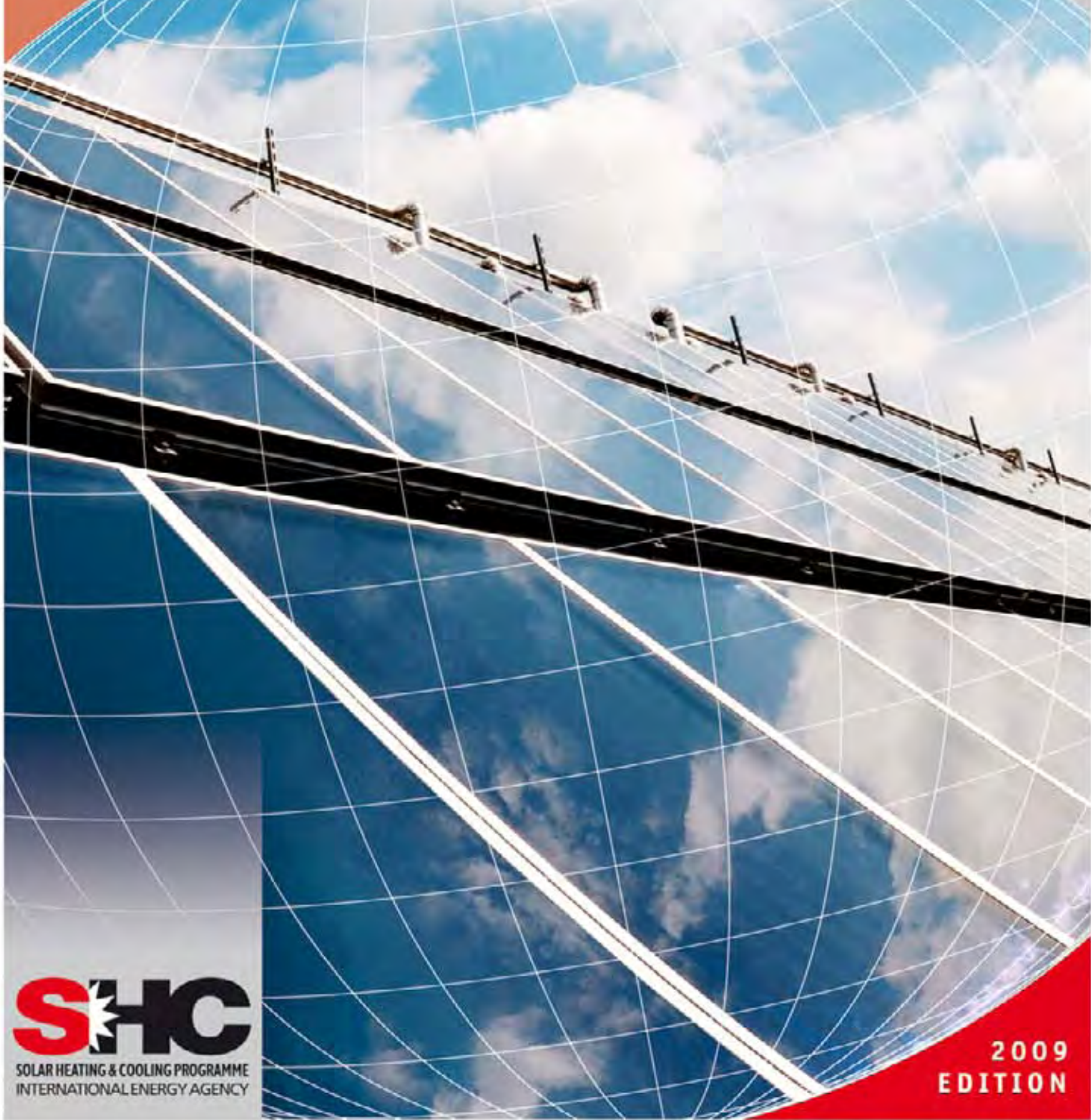


\title{
SOLAR HEAT WORLDWIDE
}

\author{
Markets and Contribution to the Energy Supply 2007
}

EDITION 2009

\author{
Werner Weiss | Irene Bergmann | Roman Stelzer \\ AEE INTEC \\ AEE - Institute for Sustainable Technologies \\ A-8200 Gleisdorf, Austria
}

IEA Solar Heating \& Cooling Programme, May 2009

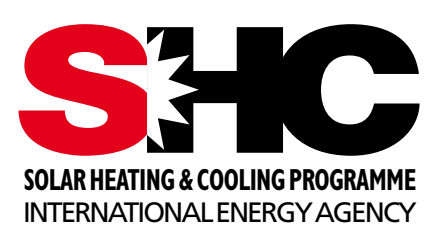

Supported by the Austrian Ministry for Transport, Innovation and Technology

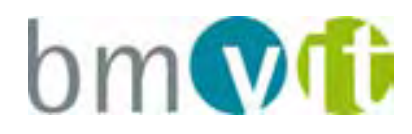

Design, Grafics, Typesetting \& Imageprocessing: STEINHUBER INFODESIGN, Graz, Austria

Notice:

The Solar Heating and Cooling Programme functions within a framework created by the International Energy Agency (IEA). Views, findings and publications of the Solar Heating and Cooling Programme do not necessarily represent the views or policies of the IEA Secretariat or of all its individual member countries. 


\section{Table of Contents}

3.1 Total capacity of glazed flat-plate and evacuated tube collectors at the end of 2007

3.2 Total capacity of glazed flat-plate and evacuated tube collectors in operation at the end of 2007 by economic region

3.3 Total capacity of unglazed water collectors in operation at the end of 2007

3.4 Total capacity of unglazed water collectors in operation by economic region at the end of 2007

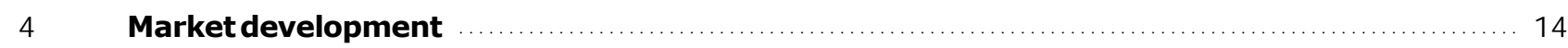

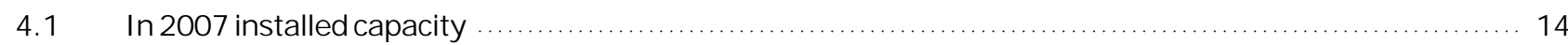

4.2 Market development of glazed flat-plate and evacuated tube collectors by economic region .............. 16

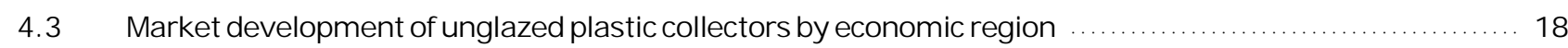

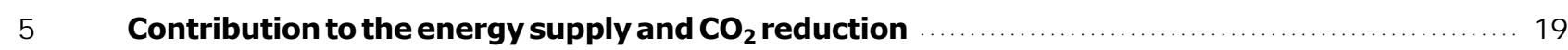

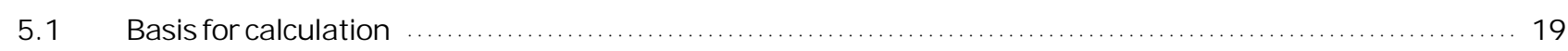

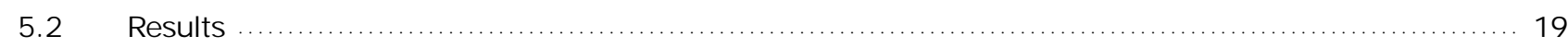

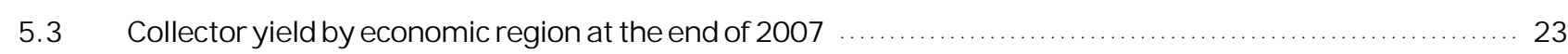

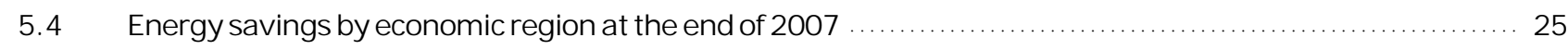

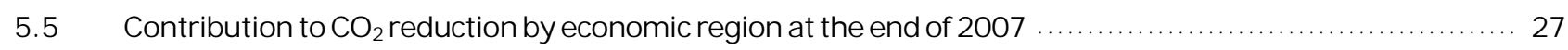

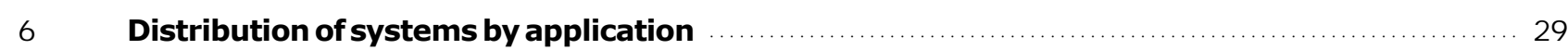

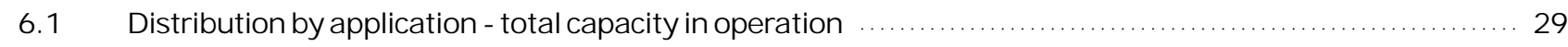

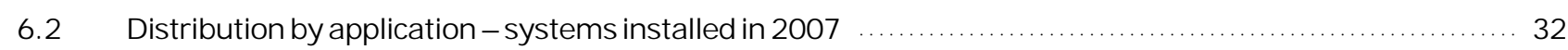

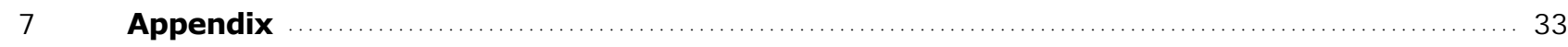

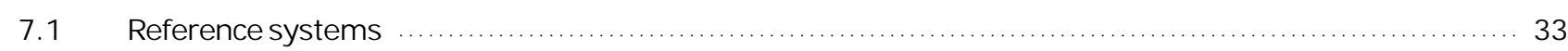

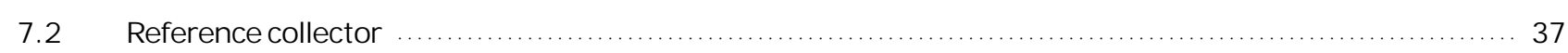

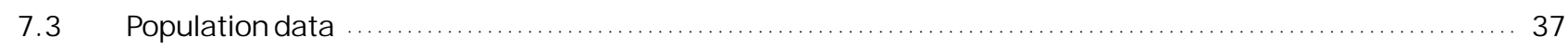

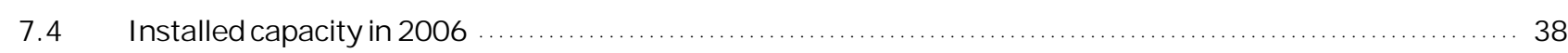

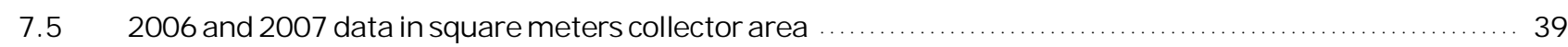

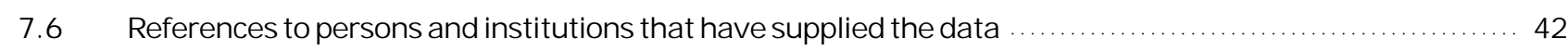

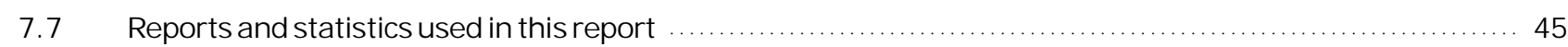

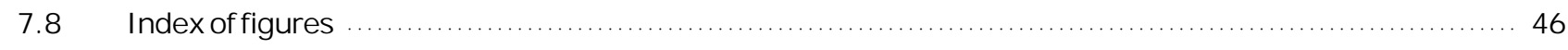

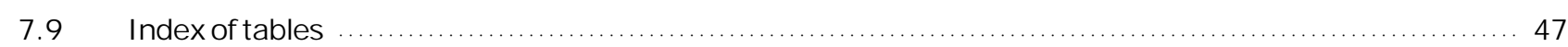




\section{$1 \quad$ Background}

This report was prepared within the framework of the Solar Heating and Cooling Programme (SHC) of the International Energy Agency (IEA). The goal of the report is to document the solar thermal capacity previously installed in the important markets worldwide, and to ascertain the contribution of solar plants to the supply of energy and the $\mathrm{CO}_{2}$ emissions avoided as a result of operating these plants. The collectors documented are unglazed collectors, glazed flat-plate and evacuated tube collectors with water as the energy carrier as well as glazed and unglazed air collectors.

The data were collected within the framework of a questionnaire survey of the national delegates of the Executive Committee of the SHC Programme and other national experts active in the field of solar thermal energy. Since some of the 49 countries included in this report have very detailed statistics and others could only provide estimates from experts, the data was checked for its plausibility on the basis of various publications.

Starting with the collector area, the capacity installed, the contributions of solar plants towards the supply of energy and the reduction of $\mathrm{CO}_{2}$ were ascertained.

The 49 countries included in this report represent 4 billion people, which is about $60 \%$ of the world's population. The installed capacity in these countries is estimated to represent $85-90 \%$ of the solar thermal market worldwide.

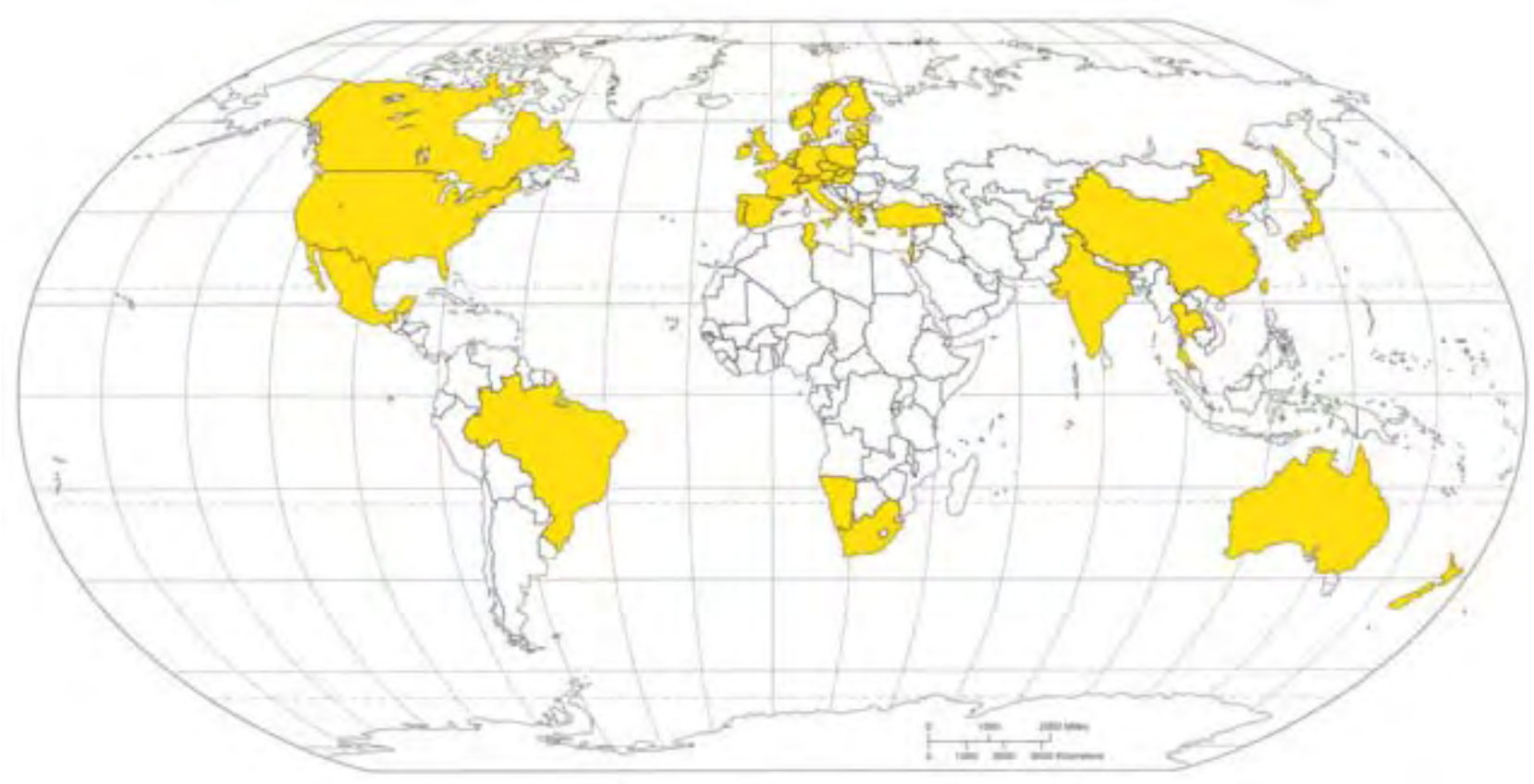

Figure 1: Countries represented in this report 


\section{Summary}

\section{Solar Thermal Capacity in Operation Worldwide}

The solar thermal collector capacity in operation worldwide equaled $146.8 \mathrm{GW}_{\text {th }}$ corresponding to 209.7 million square meters ${ }^{1} 1$ at the end of the year 2007. Of this, $120.5 \mathrm{GW}_{\text {th }}$ were accounted for by flat-plate and evacuated tube collectors and $25.1 \mathrm{GW}_{\text {th }}$ for unglazed plastic collectors. Air collector capacity was installed to an extent of $1.2 \mathrm{GW}_{\text {th }}$.

\section{Distribution by Application}

If one observes the use of solar thermal energy it becomes clear that it greatly varies in the different countries. In China and Taiwan ( $80.8 \mathrm{GW}_{\text {th }}$ ), Europe (15,9 GW th ) and J apan ( $4.9 \mathrm{GW}_{\text {th }}$ ), plants with flat-plate and evacuated tube collectors are mainly used to prepare hot water and to provide space heating while in North America (USA and Canada) swimming pool heating is still the dominant application with an installed capacity of $19.8 \mathrm{GW}_{\text {th }}$ of unglazed plastic collectors.

It should be mentioned that there is a growing unglazed solar air heating market in Canada and the USA. These unglazed air collectors are used for commercial and industrial building ventilation, air heating and agricultural applications.

Europe has the most sophisticated market for different solar thermal applications. It includes systems for hot water preparation, plants for space heating of single- and multi-family houses and hotels, large-scale plants for district heating as well as a growing number of systems for air conditioning, cooling and industrial applications.

In Austria, Germany, Switzerland and the Netherlands the share of applications other than hot water preparation in single-family houses is $20 \%$ and higher. There are about 130 large-scale plants $\left(\geq 500 \mathrm{~m}^{2} ; 350 \mathrm{~kW}_{\mathrm{th}}\right)$ in operation in Europe with a total installed capacity of $140 \mathrm{MW}_{\text {th }}$. The biggest plants for solar assisted district heating are located in Denmark with $13 \mathrm{MW}_{\text {th }}\left(18,300 \mathrm{~m}^{2}\right)$ and Sweden with $7 \mathrm{MW}_{\text {th }}\left(10,000 \mathrm{~m}^{2}\right)$. The biggest reported solar thermal system for providing industrial process heat was installed in 2007 in China. This $9 \mathrm{MW}_{\mathrm{th}}\left(13,000 \mathrm{~m}^{2}\right)$ plant generates heat for a textile company.

\section{Leading Countries}

\section{Flat-plate and evacuated tube collectors}

Focusing on the total capacity in operation of flat-plate and evacuated tube collectors installed at the end of the year

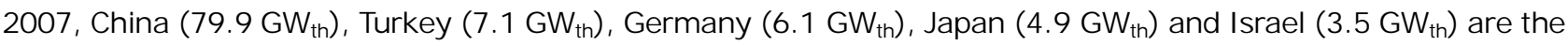
leading countries. They are followed by Brazil $\left(2.51 \mathrm{GW}_{\mathrm{th}}\right)$, Greece $\left(2.50 \mathrm{GW}_{\mathrm{th}}\right)$, Austria $\left(2.1 \mathrm{GW}_{\mathrm{th}}\right)$, the USA (1.7 $\mathrm{GW}_{\text {th }}$ ) and India $\left(1.5 \mathrm{GW}_{\text {th }}\right)$. As can be seen from these figures, China is by far the largest market, representing $66 \%$ of the world market of flat-plate and evacuated tube collectors. Here it should also be mentioned that China extended its market share by $2 \%$ in 2007 compared to 2006.

Focusing on market penetration - total capacity in operation per 1,000 inhabitants - Cyprus ( $651 \mathrm{~kW}_{\text {th }}$ ), Israel (499 $\left.\mathrm{kW}_{\text {th }}\right)$, Austria $\left(252 \mathrm{~kW}_{\mathrm{th}}\right)$, Greece $\left(224 \mathrm{~kW}_{\mathrm{th}}\right)$ and Barbados $\left(197 \mathrm{~kW}_{\mathrm{th}}\right)$ are the leading countries. They are followed by J ordan (100 kWth $)$, Turkey (95 kWth $)$, Germany $(73 \mathrm{kWt}$ th $)$, China $\left(60 \mathrm{~kW}_{\mathrm{th}}\right)$ and Australia $\left(57 \mathrm{~kW}_{\mathrm{th}}\right)$. seven countries agreed upon a methodology to convert installed collector area into solar thermal capacity at a joint meeting of the IEA SHC Programme and major solar thermal trade associations held September 2004 in Gleisdorf, Austria. The represented associations from Austria, Canada, Germany, the Netherlands, Sweden and the USA as well as the European Solar Thermal Industry Federation (ESTIF) and the IEA SHC Programme agreed to use a factor of $0.7 \mathrm{~kW}$ th $/ \mathrm{m}^{2}$ to derive the nominal capacity from the area of installed collectors. 


\section{Unglazed plastic collectors}

With regard to the heating of swimming pools with unglazed plastic collectors, the USA leads with a total capacity of $19.3 \mathrm{GW}_{\text {th }}$ in operation ahead of Australia with $2.8 \mathrm{GW}_{\mathrm{th}}$, Germany and Canada with $0.5 \mathrm{GW}_{\text {th }}$ each, and South Africa and Austria with $0.4 \mathrm{GW}_{\text {th. }}$.

The market penetration - total capacity in operation per 1,000 inhabitants - gives a slightly different picture: Australia leads with $137 \mathrm{~kW}_{\text {th }}$ ahead of the USA with $63 \mathrm{~kW}_{\text {th }}$ and Austria with $51 \mathrm{~kW}_{\text {th }}$ per 1,000 inhabitants. In fourth to sixth places there are Switzerland, the Netherlands and Canada with an installed capacity between 20 and $14 \mathrm{~kW}_{\text {th }}$.

\section{Installed capacity in 2007}

In the year 2007, a new capacity of $19.9 \mathrm{GW}_{\text {th }}$ corresponding to 28.4 million square metres of solar collectors was installed worldwide. The overall new installations grew $8.7 \%$ compared to 2006 . This represents a decrease of the growth rate compared to $2005 / 2006$ when the market grew $22 \%$. The main reasons for this were the market slumps of unglazed plastic collectors in the USA and of flat plate and evacuated tube collectors in Germany.

In 2007, flat-plate and evacuated tube collectors accounted for $18.4 \mathrm{GW}_{\text {th }}$.

It is remarkable that the global market of evacuated tube collectors grew $23.4 \%$ compared to the year 2006 , whereas the markets of flat plate collectors and unglazed collectors decreased $18.3 \%$ and $7.2 \%$ respectively.

The most dynamic markets for water collectors (unglazed, flat-plate and evacuated tube collectors) in Europe, with growth rates near and above $100 \%$ compared to the capacity installed in 2006 , were in Hungary $700 \%$, Ireland $293 \%$, Slovak Republic $200 \%$, UK $93 \%$ and Portugal $80 \%$. Besides the European countries, the markets in Namibia $74.5 \%$, Mexico $60 \%$ and Brazil 32\% have recorded a large growth rate. The number of new installations in China, the world's largest market, increased in 2007 by $17.4 \%$ compared to the number of installations in 2006.

The main markets for unglazed collectors can be found in the USA $\left(0.79 \mathrm{GW}_{\mathrm{th}}\right)$ and Australia $(0.4 \mathrm{GW}$ th $)$. South Africa, Canada, Germany, Mexico, The Netherlands, Sweden, Switzerland, Belgium and Austria also have notable markets, but all with values below $0.1 \mathrm{GW}_{\text {th }}$ of new installed unglazed collectors in 2007.

\section{Market development 1999 - 2007}

The main markets for flat-plate and evacuated tube collectors worldwide are in China and Europe as well as in Australia and New Zealand. The average annual growth rate between 1999 and 2007 was 23.6\% in China, 20\% in Europe, $26 \%$ in Canada and the USA and $16 \%$ in Australia and New Zealand. Although the installed capacity of flat-plate and evacuated tube collectors in the USA is very low compared to other countries, especially with regard to the large population in the USA, the market for new installed glazed collectors has been significantly growing in recent years.

The worldwide market of unglazed collectors for swimming pool heating recorded an increase between 1999 and 2002 and a slight decrease in 2003. After a slight increase from 2004 to 2006, the installed capacity rate declined again in 2007. 


\section{Contribution of solar collectors to the supply of energy}

The annual collector yield of all solar thermal systems in operation by the end of 2007 in the 49 recorded countries is $88,845 \mathrm{GWh}$ ( $319.841 \mathrm{TJ}$ ). This corresponds to an oil equivalent of 12.09 million tons and an annual avoidance of 39.3 million tons of $\mathrm{CO}_{2}$.

These values have been calculated from all water-based systems excluding the air systems. Since the database of the applications of air collectors is insufficient, the contribution of air collectors to the energy supply and $\mathrm{CO}_{2}$ reduction was not calculated.

Compared with other forms of renewable energy, solar heating's contribution in meeting global energy demand is, besides the traditional renewable energies like biomass and hydropower, second only to wind power, and has a much larger contribution than photovoltaics (Figure 2). This fact is still underestimated by energy policy.

Total Capacity in Operation $\left[\mathrm{GW}_{\mathrm{el}}\right],\left[\mathrm{GW}_{\mathrm{th}}\right]$ and ProducedEnergy $\left[\mathrm{TWh}_{\mathrm{el}}\right],[\mathrm{TWh}$ th, 2007

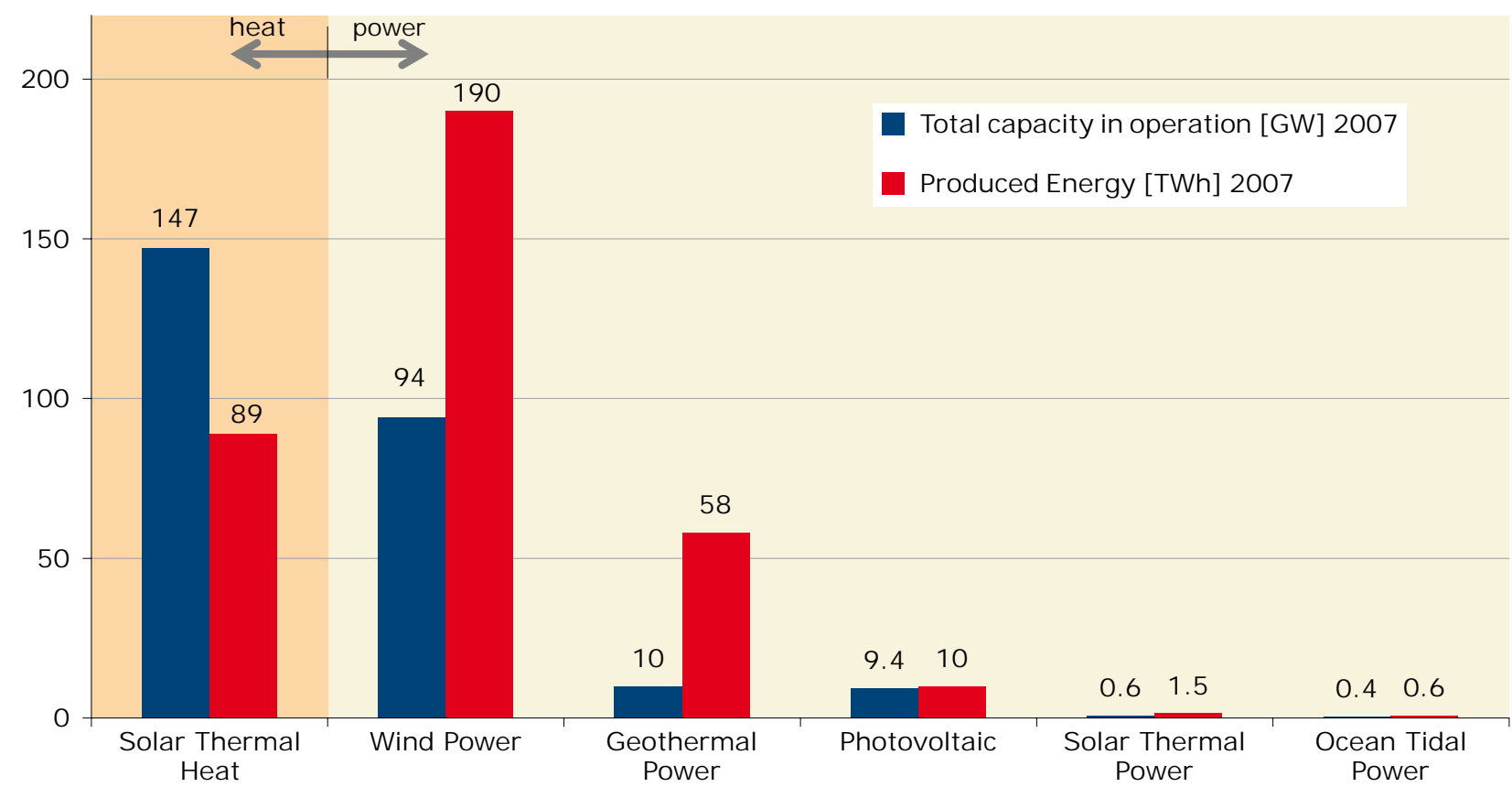

Figure 2: Total capacity in operation [ $\left.\mathrm{GW}_{\mathrm{el}}\right],\left[\mathrm{GW}_{\mathrm{th}}\right] 2006$ and annually energy generated [TWh $\left.\mathrm{el}\right],\left[\mathrm{TWh}_{\mathrm{th}}\right]$.

Sources: EPIA, GEWC, EWEA, EGEC, REN21 and IEA SHC 2008

\section{Employment}

Based on data collected from detailed country reports, the jobs created by the production, installation and maintenance of solar thermal plants is estimated to be 200,000 worldwide.

\section{Preview 2008}

Based on the data available for the year 2007 at the date of publishing this report, the total capacity in operation worldwide in 2008 can be estimated to be $165 \mathrm{GW}_{\mathrm{th}}$, corresponding to 236 million square meters of collector area. 


\section{Total capacity by the year 2007}

Since the beginning of the 1990s, the solar thermal market has undergone a favorable development. At the end of 2007, a total of 209.2 million square meters of collector area, corresponding to an installed capacity $146.8 \mathrm{GW}$ th were in operation in the 49 countries recorded in this report. These 49 countries represent 4 billion people or about $60 \%$ of the world's population. The installed capacity in these countries represents approximately $85-90 \%$ of the solar thermal market worldwide.

As shown in Table 1, the total capacity is divided into $46.39 \mathrm{GW}_{\text {th }}$ glazed flat-plate collectors (66. 3 million square meters) and $74.11 \mathrm{GW}_{\text {th }}$ evacuated tube collectors (105.9 million square meters), $25 \mathrm{GW}_{\text {th }}$ unglazed collectors (35.8 million square meters) and $1.2 \mathrm{GW}_{\text {th }}$ glazed and unglazed air collectors ( 1.7 million square meters). The distribution of the total capacity worldwide in 2007 can also be seen in Figure 3.

Figure 4 gives an overview of the 10 leading countries based on total capacities in 2007 . This figure clearly shows how the different types of collectors are applied in the different countries. China, as world leader in total capacity, is focusing very much on evacuated tube collectors, whereas the USA is holding the second position due to its high installations of unglazed collectors. Only in Australia is the unglazed collector as important as it is in the USA. The rest of the top 10 countries are clearly focusing on the flat-plate collector.

This report aims to give the actually collector area that is still in operation and not the cumulated collector area that has ever been installed in a country. The reason for this being that there is always a certain amount of collectors replaced by new systems or even taken out of operation. This explains the fact that in some countries - such as Cyprus - the total capacity published in this report for 2007 decreased compared to the data published for 2006 in the previous report.

To determine the collector area (respectively capacity) in operation, either official country reports on the lifetime base were taken into account or, if such reports were not available, a 25-year lifetime for a system was calculated. The collector area in operation was then calculated with a linear equation.

It must be stated that data of installed unglazed collectors are officially collected in just a few countries. So if there is no data given for this collector type for a country, it means there was no reliable data available. This also applies for glazed and unglazed air collectors.

In Chapter 5 collector yields, energy savings and the contribution to the $\mathrm{CO}_{2}$ reduction is calculated based on the total collector area in operation in each country. 


\begin{tabular}{|c|c|c|c|c|c|c|}
\hline \multirow{2}{*}{ Country } & \multicolumn{3}{|c|}{ Water Collectors } & \multicolumn{2}{|c|}{ Air Collectors } & \multirow{2}{*}{ TOTAL $\left[M W_{\text {th }}\right]$} \\
\hline & unglazed*** & glazed & evacuated tube & unglazed $* * *$ & glazed $* * *$ & \\
\hline Albania & & 34.95 & 0.17 & & & 35.12 \\
\hline Australia & 2,849 & $1,162.00$ & 16.10 & & & $4,027.10$ \\
\hline Austria & 426.22 & $2,064.69$ & 30.09 & & & $2,521.00$ \\
\hline Barbados & & 57.96 & & & & 57.96 \\
\hline Belgium & 34.18 & 93.63 & 8.66 & & & 136.46 \\
\hline Brazil & 68.21 & $2,511.25$ & 0.25 & & & $2,579.70$ \\
\hline Bulgaria & & 19.32 & & & & 19.32 \\
\hline Canada & 466.14 & 57.23 & 3.32 & 90.97 & 0.13 & 617.80 \\
\hline China & & $7,280.00$ & $72,618.00$ & & & $79,898.00$ \\
\hline Cyprus & & 556.32 & 0.67 & & & 557.00 \\
\hline Czech Republic & 10.66 & 67.96 & 10.84 & & & 89.47 \\
\hline Denmark & 14.96 & 275.70 & 2.38 & 2.38 & 13.13 & 308.55 \\
\hline Estonia & & 1.03 & & & & 1.03 \\
\hline Finland & 0.35 & 10.91 & 0.91 & & & 12.17 \\
\hline France * & 73.15 & 991.55 & 23.10 & & & $1,087.80$ \\
\hline Germany & 525.00 & $5,448.87$ & 604.79 & & & $6,578.65$ \\
\hline Greece & & $2,496.34$ & 4.76 & & & $2,501.10$ \\
\hline Hungary & 1.96 & 28.94 & 1.79 & & & 32.69 \\
\hline India & & $1,505.00$ & & & 11.90 & $1,516.90$ \\
\hline I reland & & 19.36 & 5.54 & & & 24.90 \\
\hline Israel & 16.94 & $3,455.83$ & & & & 3,472.77 \\
\hline Italy & 18.39 & 611.46 & 72.00 & & & 701.86 \\
\hline Japan & & $4,777.20$ & 88.95 & 304.06 & 8.76 & $5,178.96$ \\
\hline Jordan & & 588.23 & 5.04 & & & 593.27 \\
\hline Lativa & & 3.75 & & & & 3.75 \\
\hline Lithuania & & 2.42 & & & & 2.42 \\
\hline Luxembourg & & 13.23 & & & & 13.23 \\
\hline Macedonia & & 13.35 & 0.14 & & & 13.49 \\
\hline Malta & & 20.55 & & & & 20.55 \\
\hline Mexico & 327.31 & 310.72 & & & & 638.03 \\
\hline Namibia & & 4.19 & 0.13 & & & 4.32 \\
\hline Netherlands & 240.47 & 230.65 & & & & 471.12 \\
\hline New Zealand & 4.35 & 72.04 & 7.03 & & & 83.42 \\
\hline Norway & 1.12 & 7.85 & 0.11 & & 0.84 & 9.92 \\
\hline Poland & 0.91 & 138.51 & 25.71 & 2.10 & 1.75 & 168.98 \\
\hline Portugal & 0.42 & 193.23 & 3.83 & & & 197.48 \\
\hline Romania & & 48.72 & & & & 48.72 \\
\hline Slovak Republic & & 61.81 & 6.94 & & & 68.75 \\
\hline Slovenia & & 81.07 & 0.81 & & & 81.88 \\
\hline South Africa & 440.03 & 173.38 & & & & 613.40 \\
\hline Spain & 2.10 & 814.92 & 31.92 & & & 848.93 \\
\hline Sweden & 56.00 & 156.10 & 20.30 & & & 232.40 \\
\hline Switzerland ** & 148.68 & 303.44 & 17.79 & 586.60 & & $1,056.52$ \\
\hline Taiwan & & 795.84 & 82.89 & & & 878.74 \\
\hline Thailand & & 49.00 & & & & 49.00 \\
\hline Tunisia & & 151.57 & 1.03 & & & 152.60 \\
\hline Turkey & & $7,105.00$ & & & & $7,105.00$ \\
\hline United Kingdom & & 194.54 & 18.90 & & & 213.44 \\
\hline United States & $19,347.55$ & $1,329.19$ & 404.86 & 0.07 & 160.82 & $21,242.49$ \\
\hline TOTAL & $25,074.11$ & $46,390.78$ & $74,119.76$ & 986.18 & 197.33 & $146,768.15$ \\
\hline
\end{tabular}

* France: includes Overseas Departments

** Unglazed air collectors in Switzerland: this is a very simple site-built system for hay drying purposes

*** If no data is given: no reliable data base for this collector type available

Table 1: Total capacity in operation at the end of 2007 [ $\left.\mathrm{MW}_{\mathrm{th}}\right]$ 


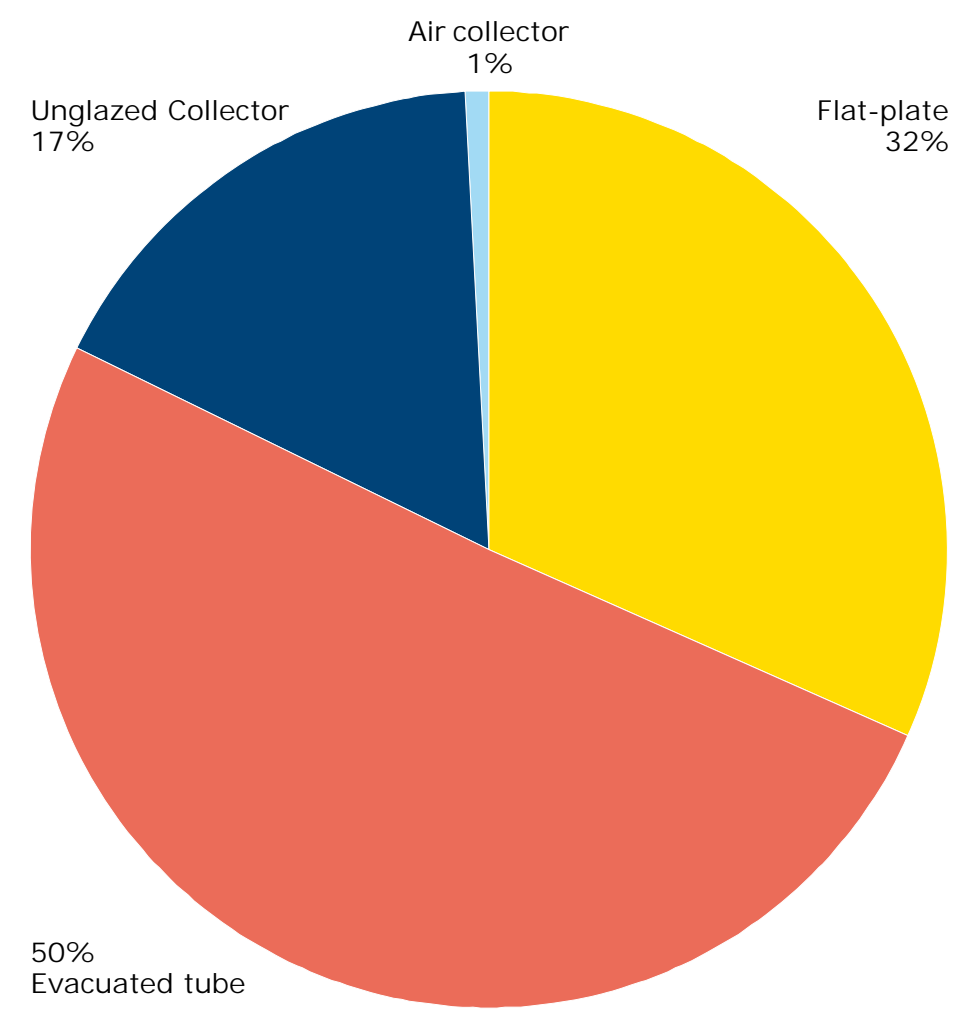

Figure 3: Distribution of the worldwide capacity in operation 2007 by collector type

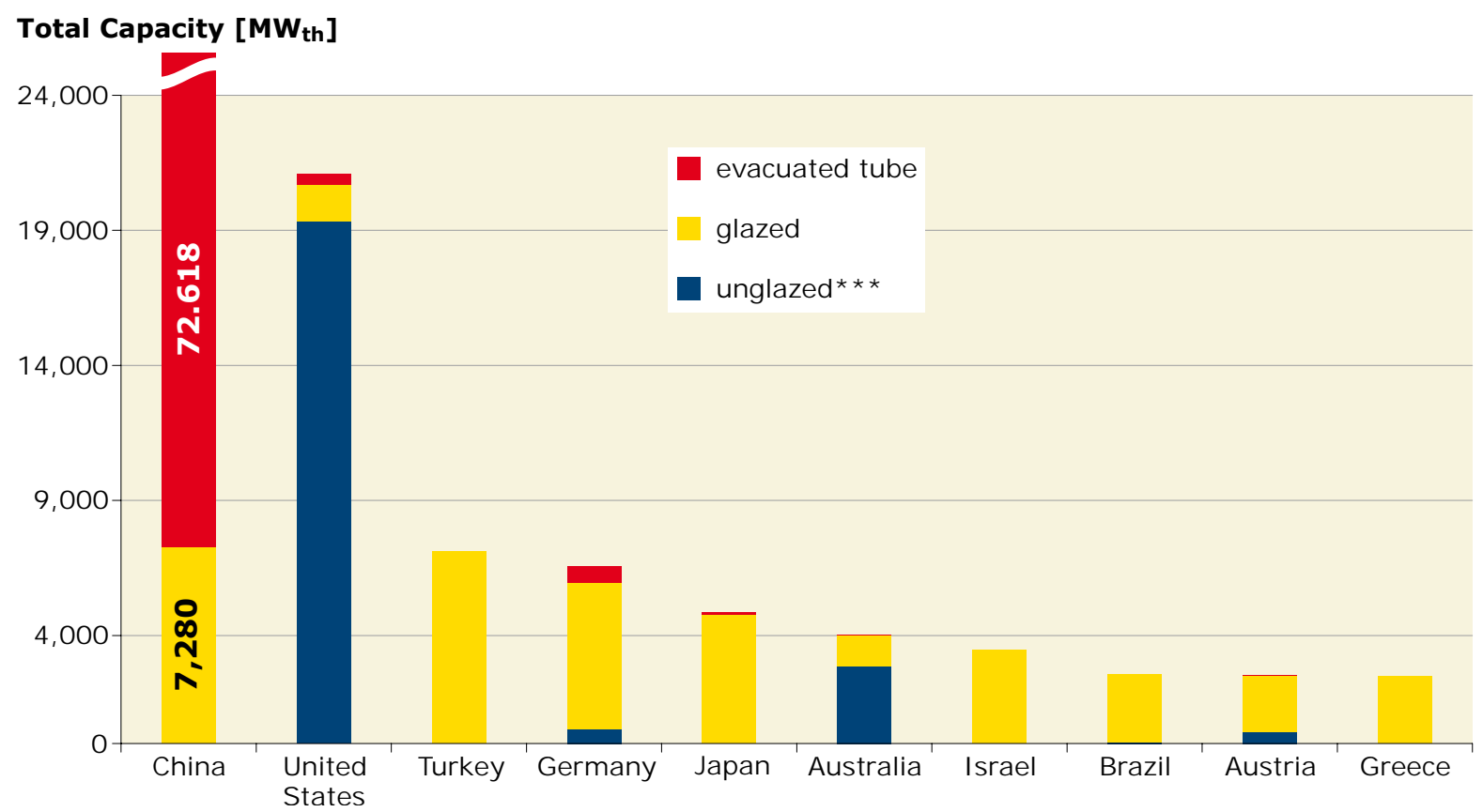

Figure 4: Total capacity in operation of water collectors of the 10 leading countries at the end of 2007 


\subsection{Total capacity of glazed flat-plate and evacuated tube collectors at the end of 2007}

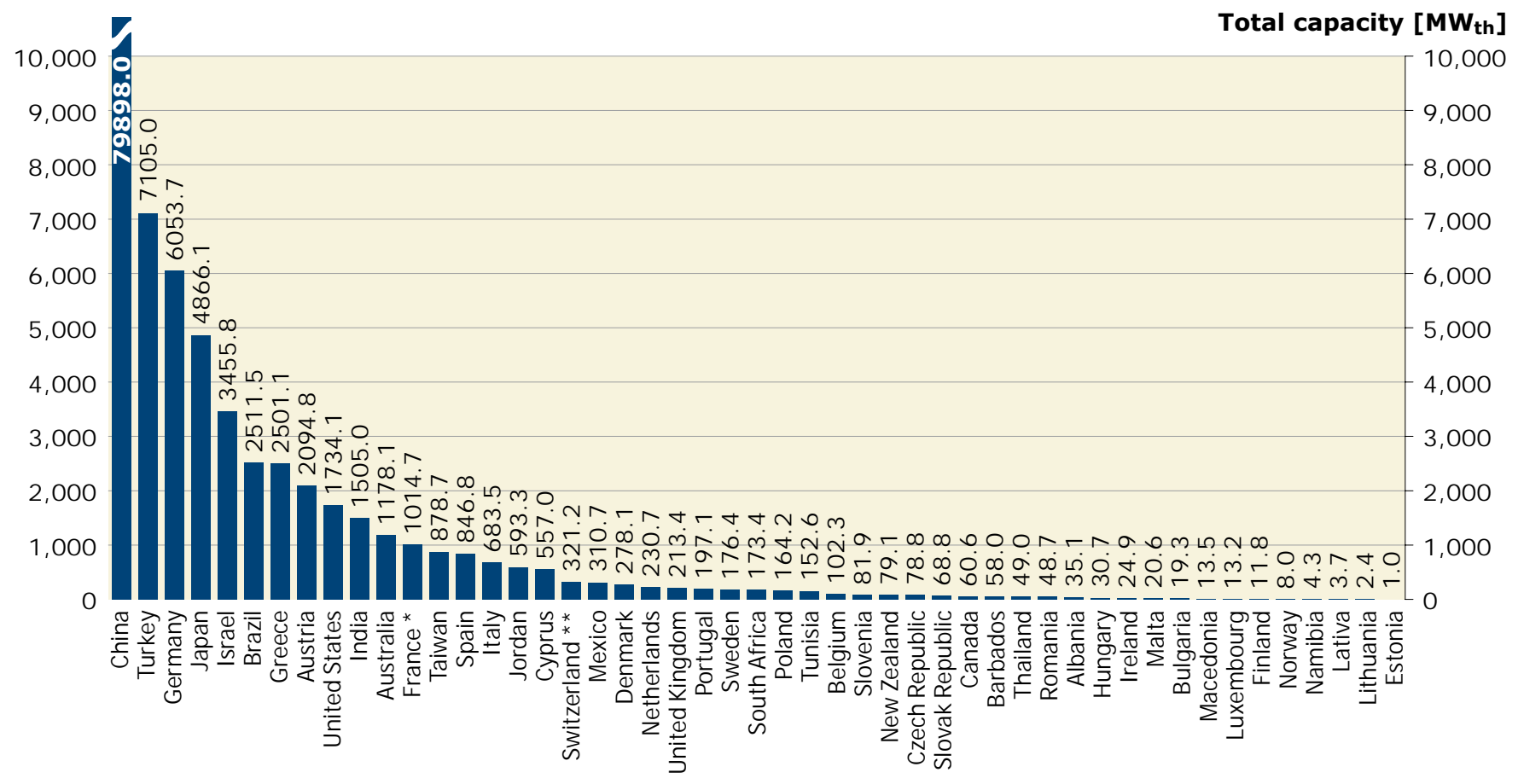

* France: includes Overseas Departments

Figure 5: Total capacity of glazed flat-plate and evacuated tube collectors in operation at the end of 2007

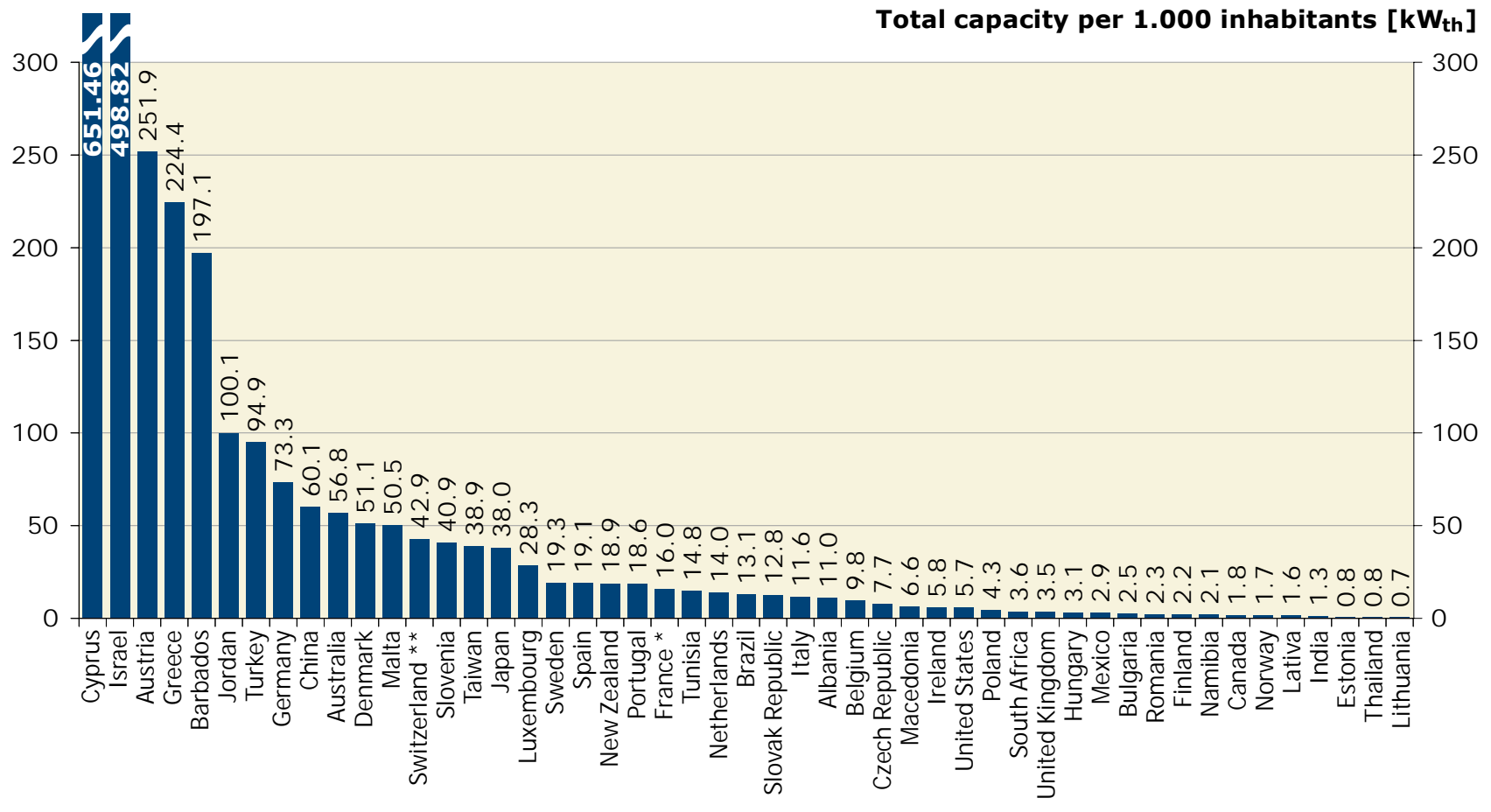

* France: includes Overseas Departments

Figure 6: Total capacity of glazed flat-plate and evacuated tube collectors in operation at the end of 2007 in $\mathrm{kW}_{\text {th }}$ per 1,000 inhabitants 


\subsection{Total capacity of glazed flat-plate and evacuated tube collectors in opera- tion at the end of $\mathbf{2 0 0 7}$ by economic region}

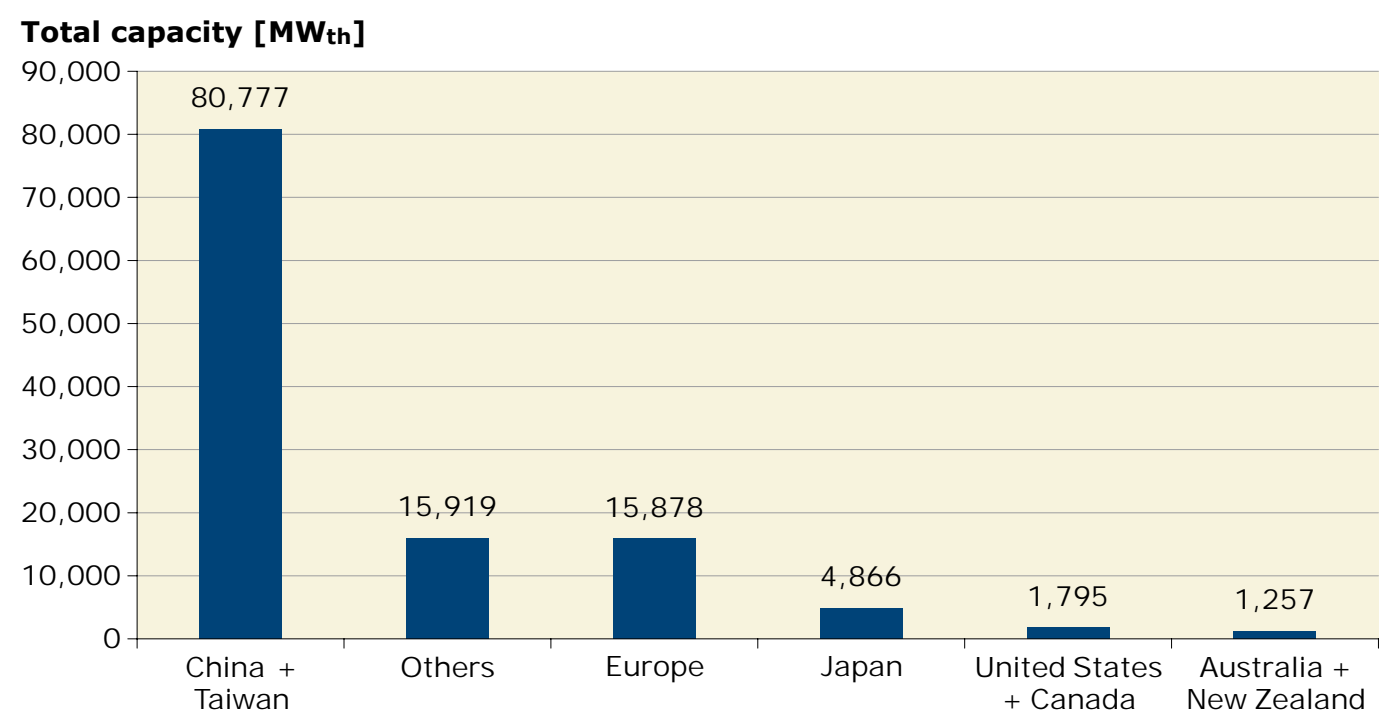

Europe: EU-27, Albania, Macedonia, Norway, Overseas Departments of France, Switzerland;

Others: Barbados, Brazil, India, I srael, J ordan, Mexico, Namibia, South Africa, Tunisia, Thailand and Turkey

Figure 7: Total capacity of glazed flat-plate and evacuated tube collectors in operation by economic region at the end of 2007

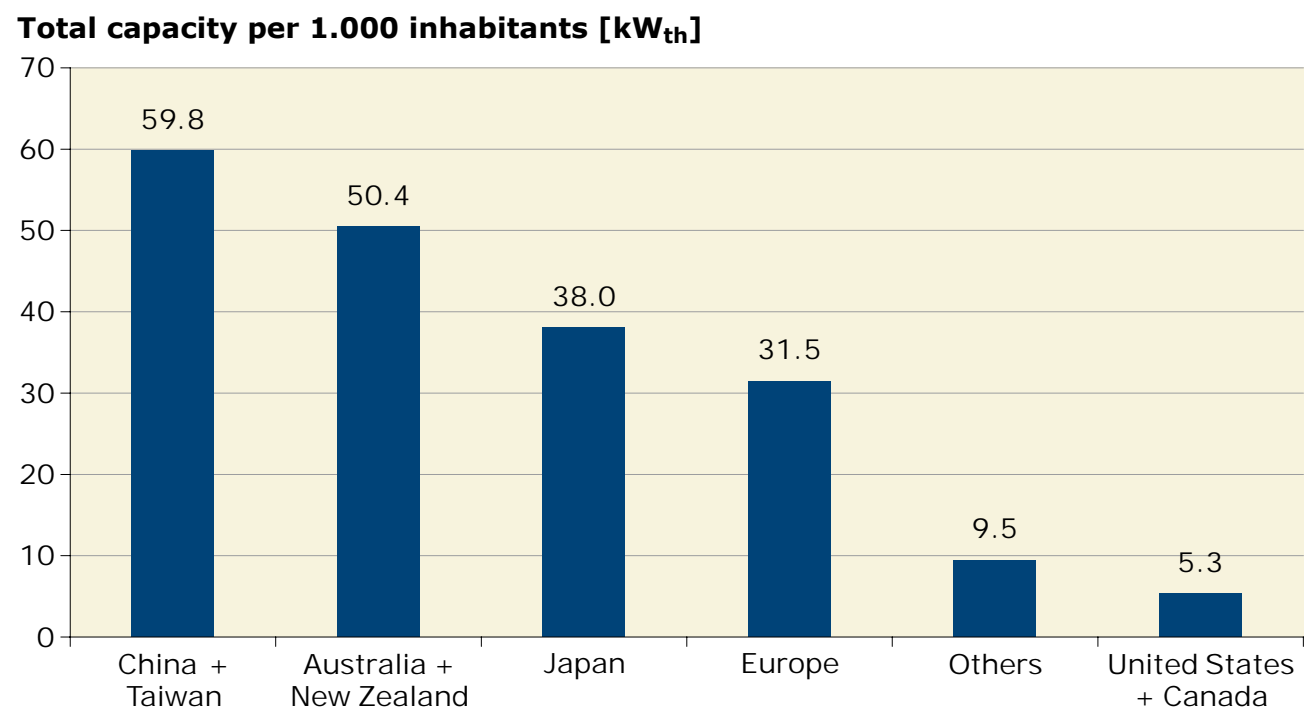

Europe: EU-27, Albania, Macedonia, Norway, Overseas Departments of France, Switzerland; Others: Barbados, Brazil, India, Israel, Jordan, Mexico, Namibia, South Africa, Tunisia and Turkey

Figure 8: Total capacity of glazed flat-plate and evacuated tube collectors in operation by economic region at the end of 2007 in $\mathrm{kW}_{\text {th }}$ per 1,000 inhabitants 


\subsection{Total capacity of unglazed water collectors in operation at the end of $\mathbf{2 0 0 7}$}

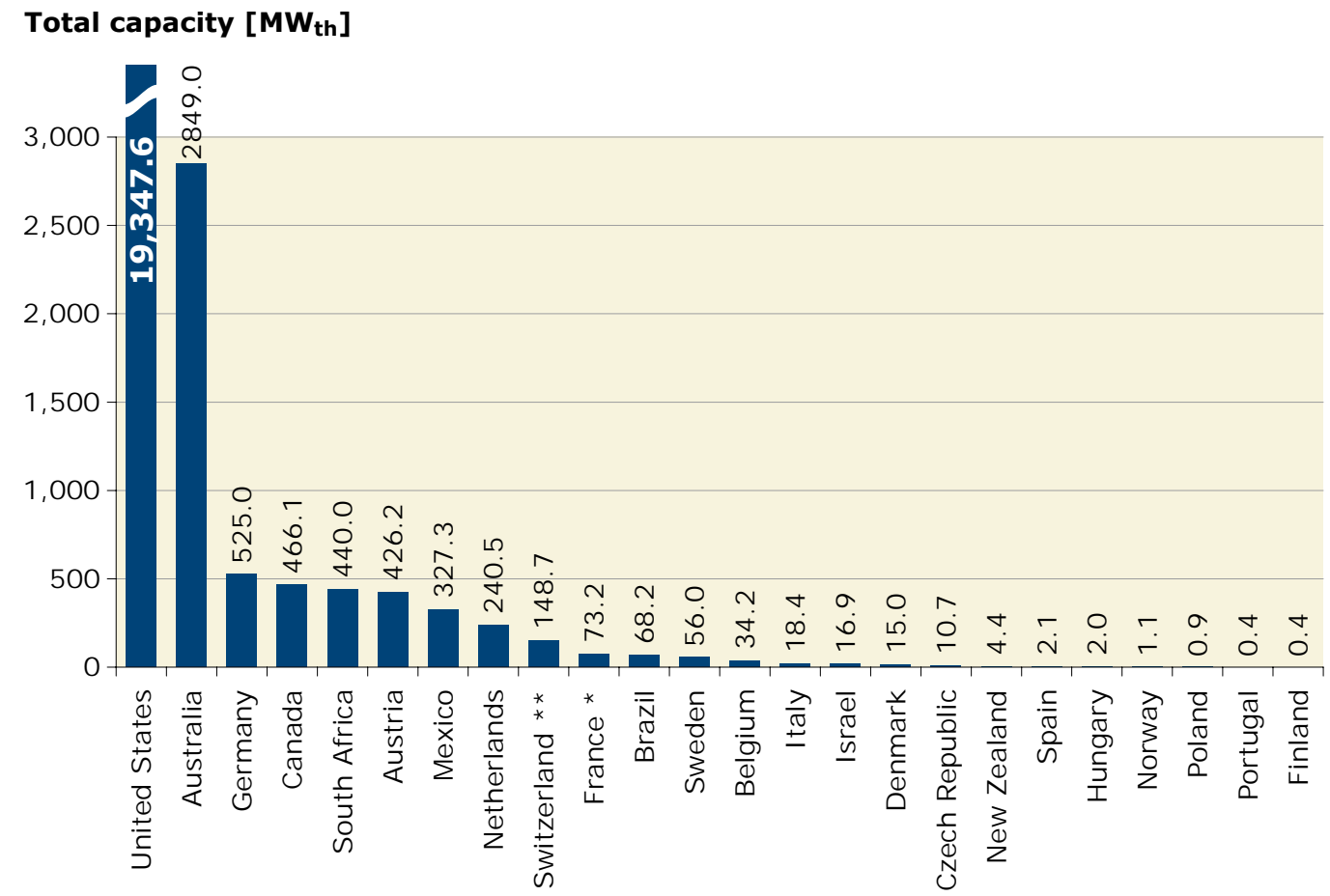

* France: includes Overseas Departments

Figure 9: Total capacity of unglazed water collectors in operation at the end of 2007

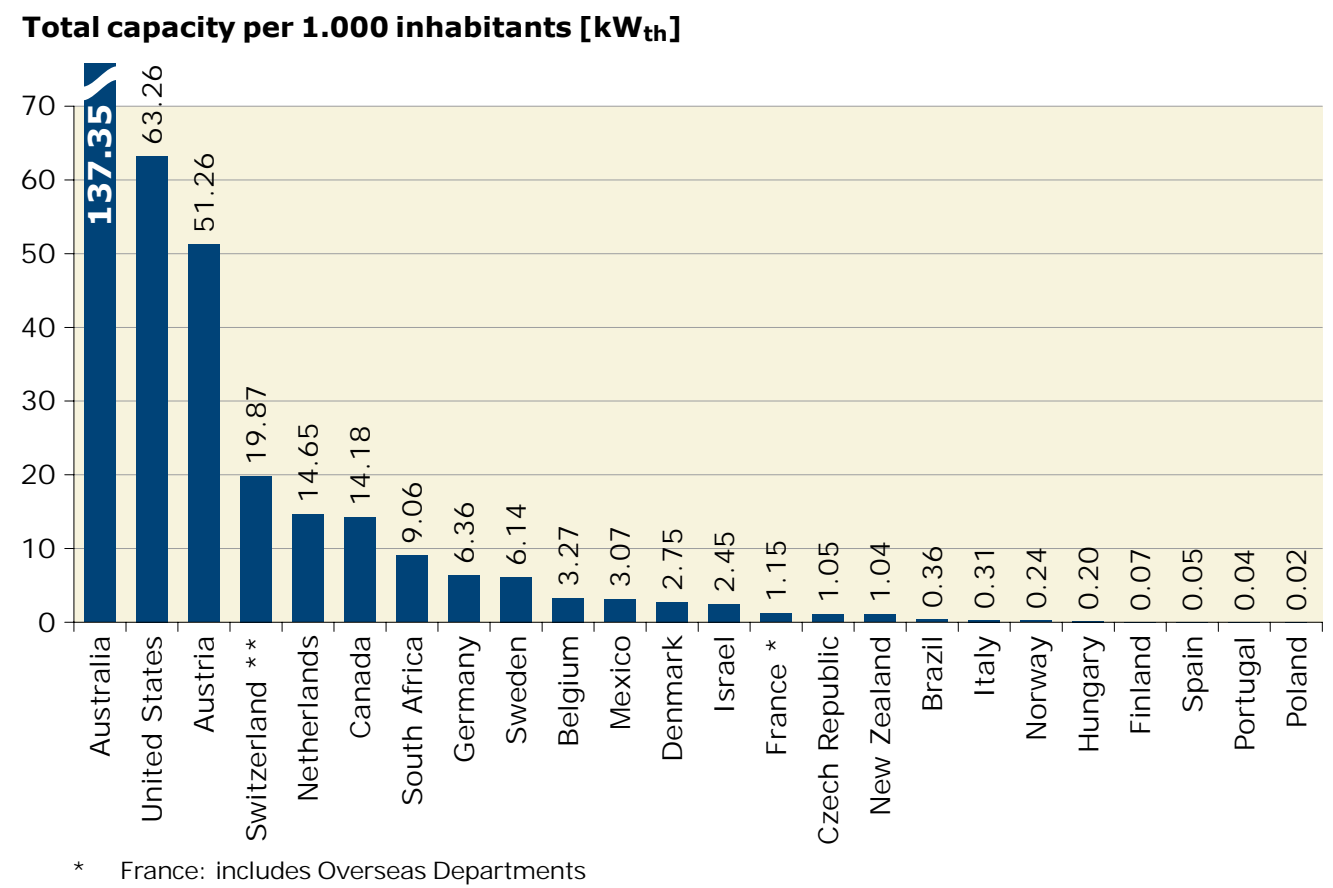

Figure 10: Total capacity of unglazed water collectors in operation at end of 2007 in $\mathrm{kW}_{\text {th }}$ per 1,000 inhabitants 


\subsection{Total capacity of unglazed water collectors in operation by economic region at the end of 2007}

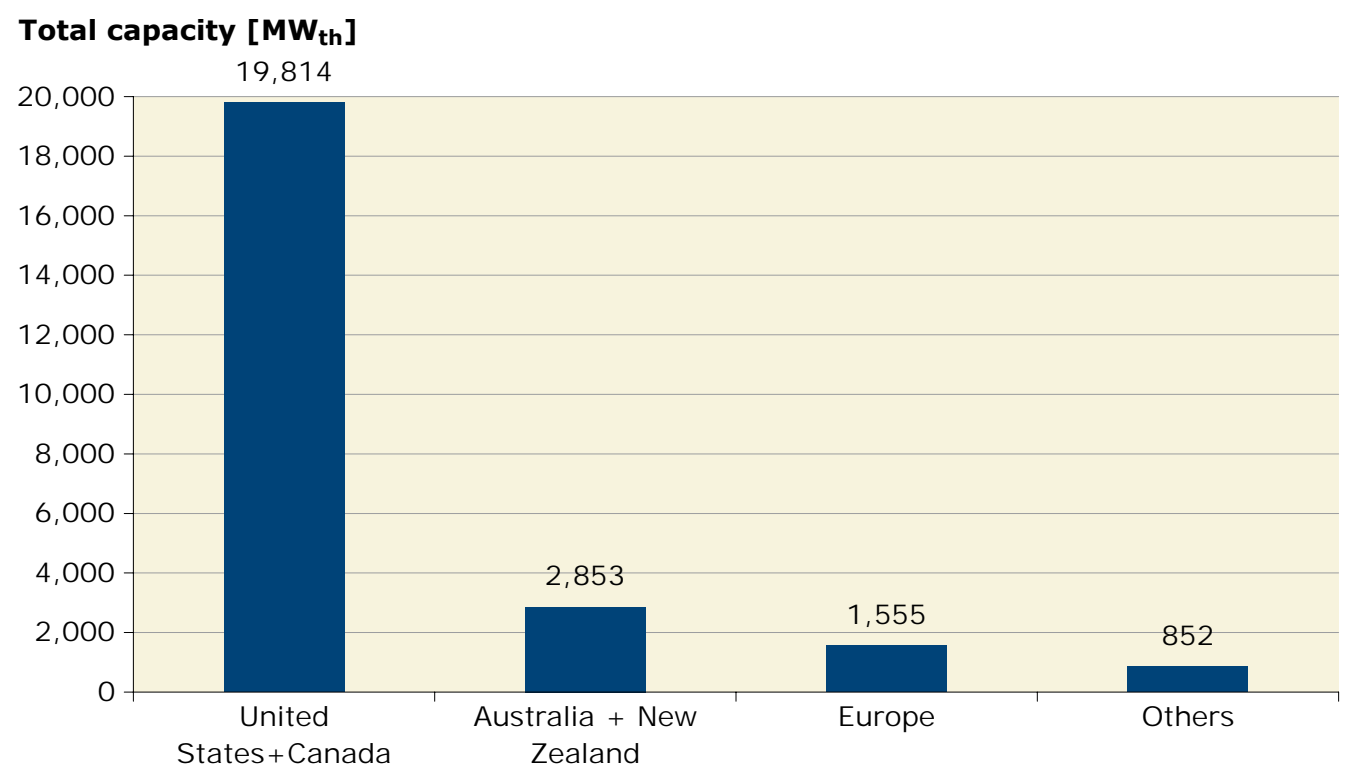

Europe: EU-27, Albania, Macedonia, Norway, Overseas Departments of France, Switzerland; Others: Barbados, Brazil, India, Israel, Jordan, Mexico, Namibia, South Africa, Tunisia and Turkey

Figure 11: Total capacity of unglazed collectors in operation by economic region at the end of 2007

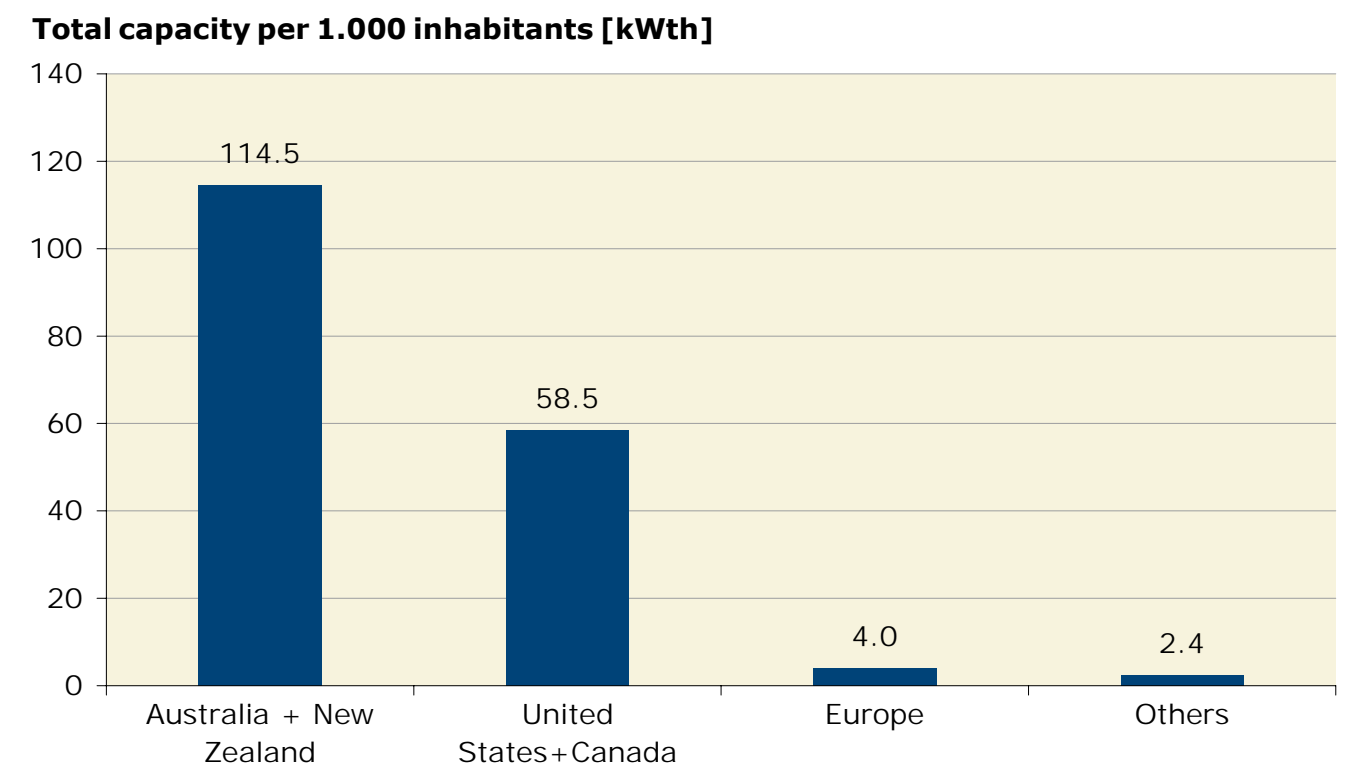

Europe: EU-27, Albania, Macedonia, Norway, Overseas Departments of France, Switzerland; Others: Barbados, Brazil, India, Israel, J ordan, Mexico, Namibia, South Africa, Tunisia, Thailand and Turkey

Figure 12: Total capacity of unglazed collectors in operation by economic region at the end of 2007 in $\mathrm{kW}_{\text {th }}$ per 1,000 inhabitants 


\section{Market development}

\subsection{In 2007 installed capacity}

In the year 2007, a capacity of $19.9 \mathrm{GW}_{\text {th }}$ corresponding to 28.4 million square metres of solar collectors, were installed worldwide. Flat-plate and evacuated tube collectors accounted for $18.4 \mathrm{GW}_{\mathrm{th}}$, which is $92.5 \%$ of the overall market. The main markets for unglazed collectors can be found in the USA ( $\left.0.8 \mathrm{GW}_{\mathrm{th}}\right)$ and Australia $\left(0.4 \mathrm{GW}_{\text {th }}\right)$. South Africa, Canada, Mexico, The Netherlands, Sweden, Switzerland and Austria also have a notable market, but all with values below $0.1 \mathrm{GW}_{\text {th }}$ of new installed unglazed collectors in 2007.

It is remarkable that the market of evacuated tube collectors grew $23.4 \%$ compared to the year 2006 , whereas the markets of flat plate collectors and unglazed collectors decreased $18.3 \%$ and $7.2 \%$ respectively.

Data of installed unglazed collectors are officially collected in just a few countries. So if there is no data given for this collector type for a country, it means there was no reliable data available. This also applies for glazed and unglazed air collectors. The following table shows the capacity installed yearly in the recorded countries in 2007 (see Table 14 for the capacity installed in 2006 in Chapter 7.5; the installed collector area in $\mathrm{m}^{2}$ is given in Tables 15 and 16 in Chapter 7.6). 


\begin{tabular}{|c|c|c|c|c|c|c|}
\hline \multirow{2}{*}{ Country } & \multicolumn{3}{|c|}{ Water Collectors } & \multicolumn{2}{|c|}{ Air Collectors } & \multirow{2}{*}{ TOTAL $\left[\mathrm{MW}_{\mathrm{th}}\right]$} \\
\hline & unglazed $* * *$ & glazed & evacuated tube & unglazed $* * *$ & glazed*** & \\
\hline Albania & & 6.50 & 0.06 & & & 6.56 \\
\hline Australia & 403.20 & 142.10 & 2.10 & & & 547.40 \\
\hline Austria & 6.06 & 194.33 & 2.38 & & & 202.78 \\
\hline Barbados & & 1.91 & & & & 1.91 \\
\hline Belgium & 6.18 & 25.90 & 3.50 & & & 35.58 \\
\hline Brazil & 68.21 & 332.78 & 0.25 & & & 401.23 \\
\hline Bulgaria & & 1.75 & & & & 1.75 \\
\hline Canada & 27.92 & 1.02 & 1.67 & 11.94 & 0.09 & 42.64 \\
\hline China & & 770.00 & $14,028.00$ & & & $14,798.00$ \\
\hline Cyprus & & 10.50 & 0.70 & & & 11.20 \\
\hline Czech Republic & 4.20 & 13.23 & 4.27 & & & 21.70 \\
\hline Denmark & 0.42 & 16.10 & 0.28 & 2.38 & 2.45 & 21.63 \\
\hline Estonia & & 0.25 & & & & 0.25 \\
\hline Finland & & 1.47 & 0.44 & & & 1.91 \\
\hline France * & 3.71 & 213.50 & 8.89 & & & 226.10 \\
\hline Germany & 21.00 & 588.00 & 70.00 & & & 679.00 \\
\hline Greece & & 195.30 & 2.80 & & & 198.10 \\
\hline Hungary & & 4.20 & 1.40 & & & 5.60 \\
\hline India & & 175.00 & & & 4.90 & 179.90 \\
\hline I reland & & 10.41 & 3.36 & & & 13.77 \\
\hline Israel & 0.49 & 49.70 & & & & 50.19 \\
\hline Italy & 2.56 & 147.00 & 24.50 & & & 174.06 \\
\hline Japan & & 116.36 & 2.84 & & 8.76 & 127.95 \\
\hline Jordan & & 5.37 & 2.52 & & & 7.89 \\
\hline Lativa & & 1.05 & & & & 1.05 \\
\hline Lithuania & & 0.49 & & & & 0.49 \\
\hline Luxembourg & & 2.10 & & & & 2.10 \\
\hline Macedonia & & 1.37 & 0.14 & & & 1.51 \\
\hline Malta & & 3.85 & & & & 3.85 \\
\hline Mexico & 32.40 & 75.59 & & & & 107.99 \\
\hline Namibia & & 1.97 & 0.13 & & & 2.10 \\
\hline Netherlands & 19.41 & 13.94 & & & & 33.35 \\
\hline New Zealand & 0.42 & 8.26 & 3.61 & & & 12.29 \\
\hline Norway & 0.14 & 0.50 & 0.04 & & & 0.68 \\
\hline Poland & & 32.92 & 14.78 & & & 47.70 \\
\hline Portugal & 0.43 & 31.14 & 3.99 & & & 35.56 \\
\hline Romania & & 0.35 & & & & 0.35 \\
\hline Slovak Republic & & 10.89 & 6.94 & & & 17.83 \\
\hline Slovenia & & 4.56 & 0.81 & & & 5.37 \\
\hline South Africa & 47.11 & 9.80 & & & & 56.91 \\
\hline Spain & 2.10 & 175.70 & 7.70 & & & 185.50 \\
\hline Sweden & 14.30 & 10.89 & 6.94 & & & 32.13 \\
\hline Switzerland ** & 7.22 & 44.12 & 1.79 & 1.40 & & 54.53 \\
\hline Taiwan & & 87.50 & 6.93 & & & 94.43 \\
\hline Thailand & & 5.60 & & & & 5.60 \\
\hline Tunisia & & 27.30 & 0.70 & & & 28.00 \\
\hline Turkey & & 490.00 & & & & 490.00 \\
\hline United Kingdom & & 18.90 & 18.90 & & & 37.80 \\
\hline United States & 787.53 & 90.73 & 14.36 & & 0.89 & 893.51 \\
\hline TOTAL & $1,455.00$ & $4,172.20$ & $14,247.69$ & 15.72 & 17.08 & $19,907.69$ \\
\hline
\end{tabular}

* France: includes Overseas Departments

** Unglazed air collectors in Switzerland: this is a very simple site-built system for hay drying purposes.

*** If no data is given: no reliable data base for this collector type available

Table 2: Installed capacity in 2007, $\mathrm{MW}_{\mathrm{th}} / \mathrm{a}$ 


\subsection{Market development of glazed flat-plate and evacuated tube collectors by economic region}

Analyzing the market development of hot water preparation and spacing heating, from 1999 to 2007, it can be seen that the market of flat-plate and evacuated tube collectors grew significantly during this time period.

The main markets for flat-plate and evacuated tube collectors worldwide are in China and Europe as well as in Australia and New Zealand. The average annual growth rate between 1999 and 2007 was $23.6 \%$ in China and Taiwan, 20\% in Europe, and $16 \%$ in Australia and New Zealand. The market for flat-plate and evacuated tube collectors is slightly growing in Canada and the USA. The European market decreased in 2007 mainly due to the negative sales in Germany.

After a peak in the 1980s because of the second oil crisis, the market in J apan went down. The Japanese Ministry of Economy, Trade and I ndustry stopped the subsidies for solar thermal systems, and without the subsidies less sytems were sold.

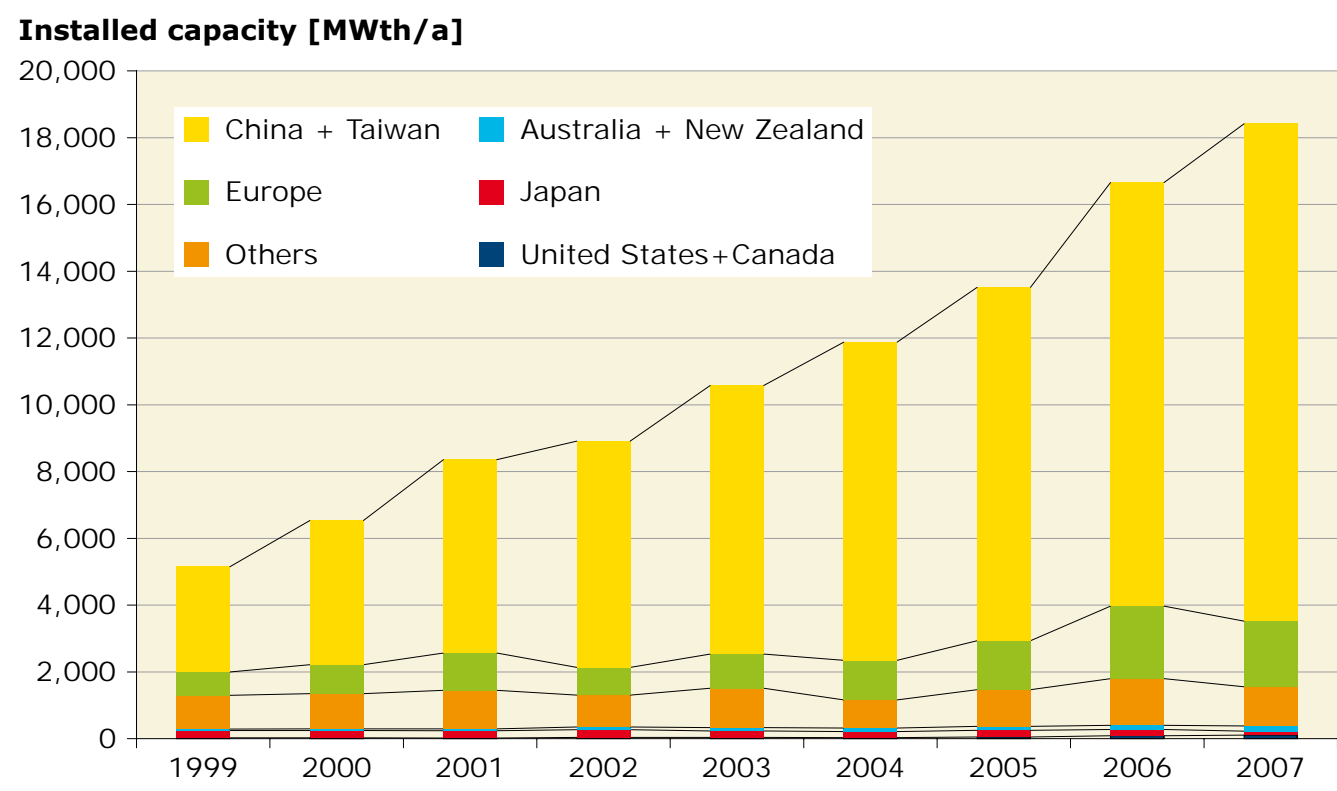

Europe: EU-27, Albania, Macedonia, Norway, Overseas Departments of France, Switzerland; Others: Barbados, Brazil, India, Israel, Jordan, Mexico, Namibia, South Africa, Thailand, Tunisia and Turkey

Figure 13: Annual installed capacity of flat-plate and evacuated tube collectors from 1999 to 2007

It should be mentioned here that the Chinese market is dominated by evacuated tube collectors, whereas in all other markets flat-plate collectors are predominant (see Figure 4). Other markets in 2007 with a significant share of evacuated tube collectors were in Germany, Italy, Poland, USA and United Kingdom. 
Figure 14 shows a different picture of the market development. In this figure the yearly installed capacity per 1,000 inhabitants is shown. Even if China looses absolute dominance due to its large population, the Chinese and Taiwanese markets are also leading in the specific collector area installed (capacity/inhabitant), ahead of Australia and New Zealand. Europe comes in at third place.

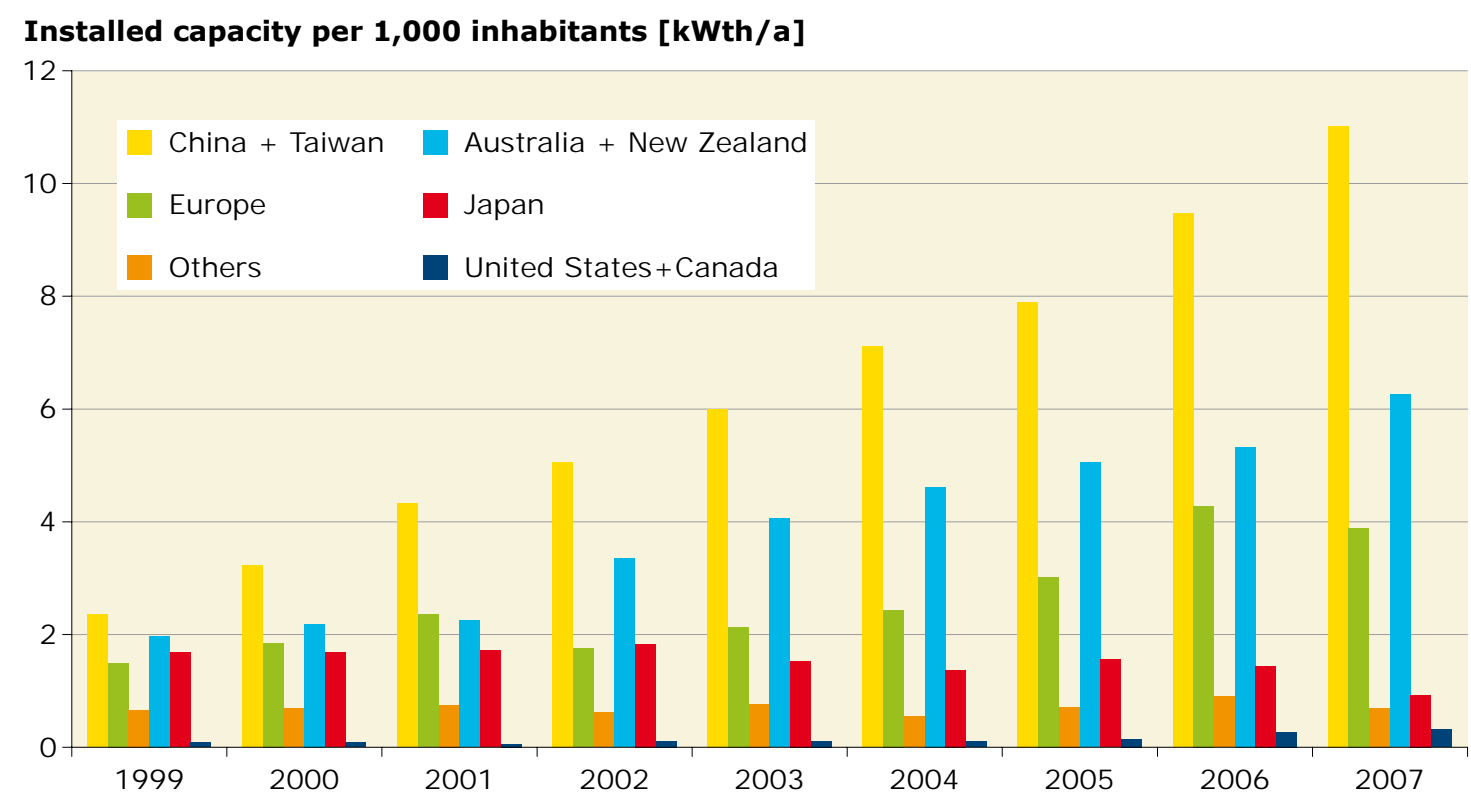

Europe: EU-27, Albania, Macedonia, Norway, Overseas Departments of France, Switzerland; Others: Barbados, Brazil, India, Israel, J ordan, Mexico, Namibia, South Africa, Thailand, Tunisia and Turkey

Figure 14: Annual installed capacity of flat-plate and evacuated tube collectors in $\mathrm{kW}_{\text {th }}$ per 1,000 inhabitants from 1999 to 2007 


\subsection{Market development of unglazed plastic collectors by economic region}

In the USA and Australia, unglazed collectors play an important role. In other big markets like China, Turkey, India and Japan, unglazed collectors almost do not exist. In Europe, the installation of unglazed collectors is almost at a constant level of about $100 \mathrm{MW}_{\text {th. }}$.

The worldwide market of unglazed collectors for swimming pool heating recorded an increase between 1999 and 2002 and a decrease in 2003. After a slight increase from 2004 to 2006 the installed capacity rate declined again in 2007, mainly caused by the major market decline in the USA and Canada (see figure 15).

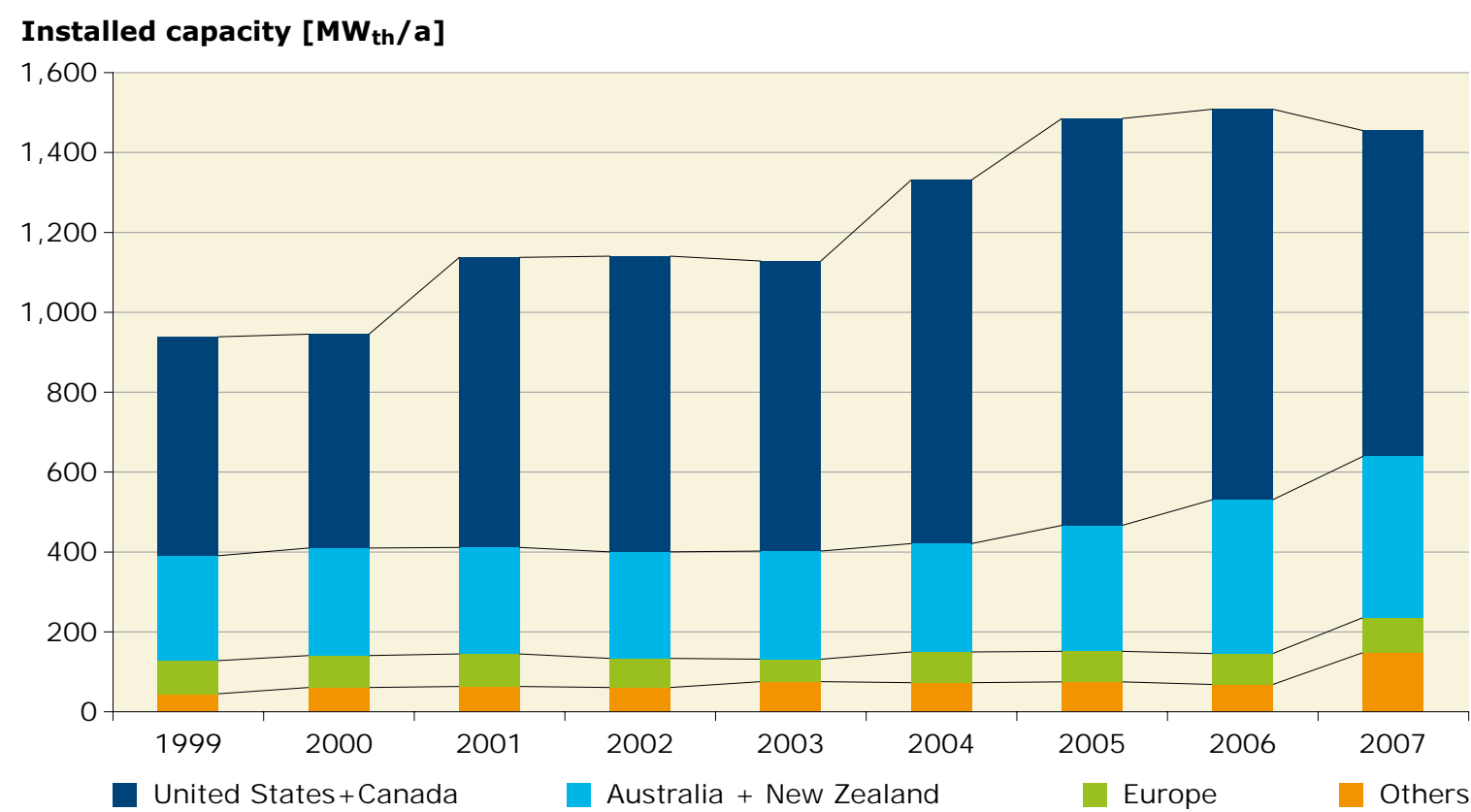

Europe: EU-27, Albania, Macedonia, Norway, Overseas Departments of France, Switzerland;

Others: Barbados, Brazil, India, Israel, Jordan, Mexico, Namibia, South Africa, Thailand, Tunisia and Turkey

Figure 15: Annual installed capacity of unglazed water collectors from 1999 to 2007 


\section{Contribution to the energy supply and $\mathrm{CO}_{2}$ reduction}

In this section, the contribution of installed water collectors to the energy supply and $\mathrm{CO}_{2}$ reduction is shown. The data for air collector applications was insufficient, therefore, the contribution of air collectors to the energy supply and $\mathrm{CO}_{2}$ reduction was not calculated.

The basis for these calculations is the total collector area in operation in each country. As shown in Table 1, a flatplate and evacuated tube collector capacity of $120.5 \mathrm{GW}_{\text {th }}$ and unglazed plastic collector capacity of $25.1 \mathrm{GW}_{\text {th }}$ was installed by the end of the year 2007 in the recorded countries.

The annual yield of these collectors is calculated to be $88,845 \mathrm{GWh}$ ( $319.841 \mathrm{TJ})$. This corresponds to an oil equivalent of 12.09 million tons and an annual avoidance of 39.3 million tons of $\mathrm{CO}_{2}$.

\subsection{Basis for calculation}

In order to ascertain the energy yield of thermal solar plants, the oil equivalent saved and the $\mathrm{CO}_{2}$ emissions avoided, the following procedure was used:

- Only water collectors were used for the calculations (unglazed, flat-plate and evacuated tube collectors). Air collector plants were not considered.

- For each country, the overall collector area installed (water collectors) was allocated to the four plant types:

- swimming pool heating

domestic hot water systems for single family houses

domestic hot water systems for multi-family houses and district heating

- solar combisystems for domestic hot water and space heating

- Reference plants were defined for each country for each type of plant.

- The number of plants for each country was ascertained from the share of collector area for each plant type and the collector area per reference system.

Reference collectors and a reference climate were determined for each country apart from the reference plants. On the basis of these reference conditions simulations were performed with the simulation program T-Sol [T-Sol, Version 4.2 Expert, dynamic simulation program to design and optimize solar thermal plants, Valentin Energiesoftware, www.valentin. de] and in this way the solar yields, energy savings and $\mathrm{CO}_{2}$ emissions were ascertained. The reference conditions, which formed the basis for the simulation, can be found in the appendix.

\subsection{Results}

The annual collector yield per square meter of collector area, depending on the application (domestic hot water preparation, space heating, etc.), the local climatic conditions and the plant dimensioning (high or low solar fraction), is between $250 \mathrm{kWh} / \mathrm{m}^{2}$ for solar combisystems for hot water preparation and space heating at high latitudes and 600 $\mathrm{kWh} / \mathrm{m}^{2}$ for plants used to prepare hot water at low latitudes.

The energy savings were ascertained from the energy equivalent of the fuel used and the rate of efficiency of the auxiliary heating system. For the auxiliary heating system, oil was taken as the fuel for all plants and the energy equivalent per liter of oil $36,700 \mathrm{~kJ}$ respectively $10.2 \mathrm{kWh}$ was used in all countries in order to achieve comparable results.

To obtain an exact statement about the $\mathrm{CO}_{2}$ emissions avoided, the substituted energy medium would have to be ascertained for each country. Since this could only be done in a very detailed survey, which goes beyond the scope of this report, the energy savings and the $\mathrm{CO}_{2}$ emissions avoided relate to oil. It is obvious that not all solar thermal systems worldwide just replace systems running on oil. This represents a simplification since gas, coal, biomass or electricity can be used as the energy source for the auxiliary heating system instead of oil. 
The $\mathrm{CO}_{2}$ emissions avoided by solar plants were ascertained from the energy savings (oil equivalent). As the emission factor $2.73 \mathrm{~kg} \mathrm{CO} 2$ per liter oil was used.

\begin{tabular}{|c|c|c|c|c|c|c|c|}
\hline Country & $\begin{array}{c}\text { Total } \\
\text { collector } \\
\text { area** } \\
{\left[\mathrm{m}^{2}\right]}\end{array}$ & $\begin{array}{c}\text { Total } \\
\text { capacity } \\
{\left[\mathrm{MW}_{\mathrm{th}}\right]}\end{array}$ & $\begin{array}{l}\text { Calculated } \\
\text { number } \\
\text { of systems }\end{array}$ & $\begin{array}{c}\text { Collector } \\
\text { yield } \\
{[\mathrm{GWh} / \mathrm{a}]}\end{array}$ & $\begin{array}{c}\text { Collector } \\
\text { yield } \\
[\mathrm{T}] / \mathrm{a}]\end{array}$ & $\begin{array}{c}\text { Energy } \\
\text { savings-oil } \\
\text { equivalent } \\
{[\mathrm{t} / \mathrm{a}]}\end{array}$ & $\begin{array}{c}\mathrm{CO}_{2} \\
\text { reduction } \\
{[\mathrm{t} / \mathrm{a}]}\end{array}$ \\
\hline Albania & 50,176 & 35.1 & 6,724 & 6.9 & 24.9 & $1,153.16$ & 3,745 \\
\hline Australia & $5,753,000$ & $4,027.1$ & 433,358 & $2,192.3$ & $7,892.3$ & $323,918.09$ & $1,052,261$ \\
\hline Austria & $3,601,431$ & $2,521.0$ & 360,154 & $1,204.5$ & $4,336.0$ & $152,306.53$ & 494,756 \\
\hline Barbados & 82,794 & 58.0 & 20,698 & 67.5 & 242.9 & $10,119.03$ & 32,848 \\
\hline Belgium & 194,946 & 136.5 & 36,774 & 64.7 & 233.1 & $7,824.17$ & 25,412 \\
\hline Brazil & $3,685,291$ & $2,579.7$ & 897,449 & $1,598.0$ & $5,753.0$ & $238,859.04$ & 775,847 \\
\hline Bulgaria & 27,600 & 19.3 & 6,900 & 12.0 & 43.2 & $2,074.97$ & 6,734 \\
\hline Canada & 752,422 & 526.7 & 17,112 & 183.1 & 659.3 & $25,187.30$ & 81,813 \\
\hline China & $114,140,000$ & $79,898.0$ & $27,484,912$ & $49,217.2$ & $177,181.8$ & $6,596,378.88$ & $21,467,451$ \\
\hline Cyprus & 795,710 & 557.0 & 195,267 & 499.1 & $1,796.9$ & $71,911.17$ & 233,427 \\
\hline Czech Republic & 127,810 & 89.5 & 18,674 & 40.1 & 144.4 & $4,794.89$ & 15,509 \\
\hline Denmark & 418,630 & 293.0 & 86,815 & 140.6 & 506.2 & $16,680.50$ & 54,178 \\
\hline Estonia & 1,470 & 1.0 & 368 & 0.5 & 1.7 & 52.48 & 171 \\
\hline Finland & 17,385 & 12.2 & 4,030 & 5.4 & 19.6 & 602.18 & 1,956 \\
\hline France* & $1,554,000$ & $1,087.8$ & 331,274 & 516.4 & $1,858.9$ & $76,849.96$ & 249,321 \\
\hline Germany & $9,398,077$ & $6,578.7$ & $1,246,190$ & $3,457.0$ & $12,445.1$ & $420,310.09$ & $1,365,272$ \\
\hline Greece & $3,573,000$ & $2,501.1$ & $1,374,890$ & $1,883.1$ & $6,779.0$ & $331,672.27$ & $1,078,740$ \\
\hline Hungary & 46,700 & 32.7 & 7,266 & 15.9 & 57.3 & $2,511.43$ & 8,162 \\
\hline India & $2,150,000$ & $1,505.0$ & 537,500 & $1,928.6$ & $6,942.8$ & $271,351.50$ & 881,500 \\
\hline I reland & 35,567 & 24.9 & 8,892 & 11.8 & 42.3 & $1,299.62$ & 4,215 \\
\hline Israel & $4,961,100$ & $3,472.8$ & $1,177,572$ & $3,643.9$ & $13,117.9$ & $492,169.12$ & $1,597,153$ \\
\hline Italy & $1,002,650$ & 701.9 & 241,981 & 424.3 & $1,527.5$ & $56,449.91$ & 183,336 \\
\hline Japan & $6,951,638$ & $4,866.1$ & $1,682,760$ & $3,316.5$ & $11,939.2$ & $418,423.96$ & $1,359,003$ \\
\hline Jordan & 847,532 & 593.3 & 207,984 & 594.7 & $2,140.9$ & $103,247.20$ & 335,330 \\
\hline Lativa & 5,350 & 3.7 & 1,338 & 1.8 & 6.5 & 207.85 & 677 \\
\hline Lithuania & 3,450 & 2.4 & 863 & 1.1 & 4.1 & 135.48 & 439 \\
\hline Luxembourg & 18,900 & 13.2 & 4,725 & 6.5 & 23.5 & 762.05 & 2,481 \\
\hline Macedonia & 19,270 & 13.5 & 4,198 & 7.2 & 25.9 & $1,250.80$ & 4,061 \\
\hline Malta & 29,360 & 20.6 & 7,340 & 9.2 & 33.0 & $2,817.68$ & 9,153 \\
\hline Mexico & 911,473 & 638.0 & 39,801 & 435.8 & $1,568.9$ & $69,380.28$ & 225,359 \\
\hline Namibia & 6,169 & 4.3 & 1,542 & 3.1 & 11.0 & 598.52 & 1,932 \\
\hline Netherlands & 673,033 & 471.1 & 94,693 & 162.9 & 586.3 & $18,809.35$ & 61,072 \\
\hline New Zealand & 119,177 & 83.4 & 26,972 & 35.4 & 127.4 & $4,723.21$ & 15,346 \\
\hline Norway & 12,970 & 9.1 & 1,873 & 4.1 & 14.7 & 451.53 & 1,467 \\
\hline Poland & 235,897 & 165.1 & 28,737 & 76.5 & 275.4 & $9,794.75$ & 31,795 \\
\hline Portugal & 282,109 & 197.5 & 67,144 & 176.9 & 637.0 & $24,275.33$ & 78,848 \\
\hline J ordan & 69,600 & 48.7 & 17,400 & 32.2 & 115.9 & $5,086.37$ & 16,530 \\
\hline Slovak Republic & 98,215 & 68.8 & 16,369 & 39.3 & 141.6 & $4,950.04$ & 16,075 \\
\hline Slovenia & 116,965 & 81.9 & 19,151 & 42.2 & 151.8 & $5,205.04$ & 16,898 \\
\hline South Africa & 876,290 & 613.4 & 65,063 & 226.5 & 815.4 & $32,345.38$ & 105,018 \\
\hline Spain & $1,212,764$ & 848.9 & 288,544 & 739.4 & $2,661.9$ & $93,614.35$ & 304,089 \\
\hline Sweden & 332,000 & 232.4 & 22,240 & 124.6 & 448.6 & $11,976.46$ & 38,887 \\
\hline Switzerland & 671,310 & 469.9 & 60,690 & 195.9 & 705.4 & $23,663.94$ & 76,853 \\
\hline Taiwan & $1,255,340$ & 878.7 & 313,835 & 629.6 & $2,266.4$ & $93,585.60$ & 304,420 \\
\hline Thailand & 70,000 & 49.0 & 17,500 & 47.7 & 171.7 & $9,937.20$ & 31,483 \\
\hline Tunisia & 218,000 & 152.6 & 54,500 & 145.4 & 523.5 & $27,010.20$ & 87,800 \\
\hline Turkey & $10,150,000$ & $7,105.0$ & $2,304,050$ & $6,050.5$ & $21,781.9$ & $807,693.56$ & $2,626,236$ \\
\hline United Kingdom & 304,920 & 213.4 & 76,230 & 101.6 & 365.6 & $12,211.13$ & 39,670 \\
\hline United States & $30,116,580$ & $21,081.6$ & 551,066 & $8,848.3$ & $31,854.1$ & $1,275,575.53$ & $4,143,322$ \\
\hline TOTAL & $207,978,070$ & 145,585 & $40,471,410$ & 89,168 & 321,004 & $12,162,209$ & $39,548,052$ \\
\hline
\end{tabular}

* France: includes Overseas Departments

** Unglazed, Glazed Flat-Plate and Evacuated Tube Water Collectors

Table 3: Calculated collector yield and corresponding oil equivalent as well as $\mathrm{CO}_{2}$ reduction of all solar thermal systems (systems for hot water, space heating and swimming pool heating) at the end of 2007 


\begin{tabular}{|c|c|c|c|c|c|c|c|}
\hline Country & $\begin{array}{c}\text { Total } \\
\text { collector } \\
\text { area** } \\
{\left[\mathrm{m}^{2}\right]}\end{array}$ & $\begin{array}{c}\text { Total } \\
\text { capacity } \\
{\left[\mathrm{MW}_{\mathrm{th}}\right]}\end{array}$ & $\begin{array}{c}\text { Number } \\
\text { of systems }\end{array}$ & $\begin{array}{c}\text { Collector } \\
\text { yield } \\
{[\mathrm{GWh} / \mathrm{a}]}\end{array}$ & $\begin{array}{c}\text { Collector } \\
\text { yield } \\
[T] / a]\end{array}$ & $\begin{array}{c}\text { Energy } \\
\text { savings - oil } \\
\text { equivalent } \\
{[\mathrm{t} / \mathrm{a}]}\end{array}$ & $\begin{array}{c}\mathrm{CO}_{2} \\
\text { reduction } \\
{[\mathrm{t} / \mathrm{a}]}\end{array}$ \\
\hline Albania & 50,176 & 35.1 & 6,724 & 6.9 & 24.9 & 1,153 & 3,745 \\
\hline Australia & $1,683,000$ & $1,178.1$ & 413,008 & 693.1 & $2,495.2$ & 100,959 & 328,058 \\
\hline Austria & $2,992,541$ & $2,094.8$ & 357,110 & $1,066.5$ & $3,839.3$ & 133,375 & 433,262 \\
\hline Barbados & 82,794 & 58.0 & 20,698 & 67.5 & 242.9 & 10,119 & 32,848 \\
\hline Belgium & 146,118 & 102.3 & 36,530 & 56.6 & 203.7 & 6,662 & 21,636 \\
\hline Brazil & $3,587,849$ & $2,511.5$ & 896,962 & $1,576.0$ & $5,673.5$ & 235,829 & 766,006 \\
\hline Bulgaria & 27,600 & 19.3 & 6,900 & 12.0 & 43.2 & 2,075 & 6,734 \\
\hline Canada & 86,502 & 60.6 & 13,783 & 39.6 & 142.5 & 4,686 & 15,221 \\
\hline China & $114,140,000$ & $79,898.0$ & $27,484,912$ & $49,217.2$ & $177,181.8$ & $6,596,379$ & $21,467,451$ \\
\hline Cyprus & 795,710 & 557.0 & 195,267 & 499.1 & $1,796.9$ & 71,911 & 233,427 \\
\hline Czech Republic & 112,580 & 78.8 & 18,598 & 35.6 & 128.1 & 4,360 & 14,086 \\
\hline Denmark & 397,260 & 278.1 & 86,709 & 137.3 & 494.3 & 16,215 & 52,665 \\
\hline Estonia & 1,470 & 1.0 & 368 & 0.5 & 1.7 & 52 & 171 \\
\hline Finland & 16,885 & 11.8 & 4,027 & 5.4 & 19.4 & 594 & 1,928 \\
\hline France* & $1,449,500$ & $1,014.7$ & 330,752 & 495.8 & $1,784.9$ & 73,862 & 239,615 \\
\hline Germany & $8,648,077$ & $6,053.7$ & $1,242,440$ & $3,295.8$ & $11,864.7$ & 396,865 & $1,289,119$ \\
\hline Greece & $3,573,000$ & $2,501.1$ & $1,374,890$ & $1,883.1$ & $6,779.0$ & 331,672 & $1,078,740$ \\
\hline Hungary & 43,900 & 30.7 & 7,252 & 15.1 & 54.4 & 2,396 & 7,786 \\
\hline India & $2,150,000$ & $1,505.0$ & 537,500 & $1,928.6$ & $6,942.8$ & 271,352 & 881,500 \\
\hline I reland & 35,567 & 24.9 & 8,892 & 11.8 & 42.3 & 1,300 & 4,215 \\
\hline Israel & $4,936,900$ & $3,455.8$ & $1,177,451$ & $3,642.4$ & $13,112.8$ & 490,797 & $1,592,698$ \\
\hline Italy & 976,380 & 683.5 & 241,849 & 418.8 & $1,507.6$ & 55,622 & 180,648 \\
\hline Japan & $6,951,638$ & $4,866.1$ & $1,682,760$ & $3,316.5$ & $11,939.2$ & 418,424 & $1,359,003$ \\
\hline Jordan & 847,532 & 593.3 & 207,984 & 594.7 & $2,140.9$ & 103,247 & 335,330 \\
\hline Lativa & 5,350 & 3.7 & 1,338 & 1.8 & 6.5 & 208 & 677 \\
\hline Lithuania & 3,450 & 2.4 & 863 & 1.1 & 4.1 & 135 & 439 \\
\hline Luxembourg & 18,900 & 13.2 & 4,725 & 6.5 & 23.5 & 762 & 2,481 \\
\hline Macedonia & 19,270 & 13.5 & 4,198 & 7.2 & 25.9 & 1,251 & 4,061 \\
\hline Malta & 29,360 & 20.6 & 7,340 & 9.2 & 33.0 & 2,818 & 9,153 \\
\hline Mexico & 443,880 & 310.7 & 37,463 & 300.2 & $1,080.6$ & 49,071 & 159,392 \\
\hline Namibia & 6,169 & 4.3 & 1,542 & 3.1 & 11.0 & 599 & 1,932 \\
\hline Netherlands & 329,506 & 230.7 & 92,976 & 111.0 & 399.6 & 11,626 & 37,739 \\
\hline New Zealand & 112,960 & 79.1 & 26,941 & 34.0 & 122.4 & 4,522 & 14,694 \\
\hline Norway & 11,370 & 8.0 & 1,865 & 3.9 & 13.9 & 421 & 1,369 \\
\hline Poland & 234,597 & 164.2 & 28,730 & 76.2 & 274.4 & 9,757 & 31,671 \\
\hline Portugal & 281,515 & 197.1 & 67,141 & 176.8 & 636.5 & 24,254 & 78,779 \\
\hline Romania & 69,600 & 48.7 & 17,400 & 32.2 & 115.9 & 5,086 & 16,530 \\
\hline Slovac Republic & 98,215 & 68.8 & 16,369 & 39.3 & 141.6 & 4,950 & 16,075 \\
\hline Slovenia & 116,965 & 81.9 & 19,151 & 42.2 & 151.8 & 5,205 & 16,898 \\
\hline South Africa & 247,680 & 173.4 & 61,920 & 108.4 & 390.1 & 15,760 & 51,146 \\
\hline Spain & $1,209,764$ & 846.8 & 288,529 & 738.5 & $2,658.7$ & 93,482 & 303,660 \\
\hline Sweden & 252,000 & 176.4 & 21,840 & 113.9 & 410.1 & 10,586 & 34,370 \\
\hline Switzerland & 458,910 & 321.2 & 59,628 & 159.1 & 572.8 & 18,564 & 60,289 \\
\hline Taiwan & $1,255,340$ & 878.7 & 313,835 & 629.6 & $2,266.4$ & 93,586 & 304,420 \\
\hline Thailand & 70,000 & 49.0 & 17,500 & 47.7 & 171.7 & 9,937 & 31,483 \\
\hline Tunisia & 218,000 & 152.6 & 54,500 & 145.4 & 523.5 & 27,010 & 87,800 \\
\hline Turkey & $10,150,000$ & $7,105.0$ & $2,304,050$ & $6,050.5$ & $21,781.9$ & 807,694 & $2,626,236$ \\
\hline $\begin{array}{l}\text { United King- } \\
\text { dom }\end{array}$ & 304,920 & 213.4 & 76,230 & 101.6 & 365.6 & 12,211 & 39,670 \\
\hline United States & $2,477,217$ & $1,734.1$ & 412,869 & $1,420.3$ & $5,113.0$ & 198,896 & 646,099 \\
\hline TOTAL & $172,157,916$ & 120,511 & $40,292,309$ & 79,375 & 285,750 & $10,738,296$ & $34,922,955$ \\
\hline
\end{tabular}

\footnotetext{
* France: includes Overseas Departments
}

** Flat-plate and evacuated tube collectors

Table 4: Calculated collector yield and corresponding oil equivalent as well as $\mathrm{CO}_{2}$ reduction of solar thermal systems for hot water preparation and space heating with flat-plate and evacuated tube collectors at the end of 2007. 


\begin{tabular}{|c|c|c|c|c|c|c|c|}
\hline Country & $\begin{array}{c}\text { Total } \\
\text { collector } \\
\text { area*** } \\
{\left[\mathrm{m}^{2}\right]}\end{array}$ & $\begin{array}{c}\text { Total } \\
\text { capacity } \\
{\left[\mathrm{MW}_{\mathrm{th}}\right]}\end{array}$ & $\begin{array}{c}\text { Calculated } \\
\text { number } \\
\text { of systems }\end{array}$ & $\begin{array}{c}\text { Collector } \\
\text { yield } \\
{[G W h / a]} \\
\end{array}$ & $\begin{array}{c}\text { Collector } \\
\text { yield } \\
{[\mathrm{T} J / \mathrm{a}]}\end{array}$ & $\begin{array}{c}\text { Energy } \\
\text { savings - oil } \\
\text { equivalent } \\
{[\mathrm{t} / \mathrm{a}]}\end{array}$ & $\begin{array}{c}\mathrm{CO}_{2} \\
\text { reduction } \\
{[\mathrm{t} / \mathrm{a}]}\end{array}$ \\
\hline \multicolumn{8}{|l|}{ Albania } \\
\hline Australia & $4,070,000$ & $2,849.00$ & $20,350.00$ & $1,499.18$ & $5,397.06$ & $222,958.75$ & $724,203.59$ \\
\hline Austria & 608,890 & 426.22 & $3,044.45$ & 137.98 & 496.73 & $18,931.97$ & $61,494.24$ \\
\hline \multicolumn{8}{|l|}{ Barbados } \\
\hline Belgium & 48,828 & 34.18 & 244.14 & 8.18 & 29.44 & $1,162.50$ & $3,775.97$ \\
\hline Brazil & 97,442 & 68.21 & 487.21 & 22.08 & 79.49 & $3,029.73$ & $9,841.06$ \\
\hline \multicolumn{8}{|l|}{ Bulgaria } \\
\hline Canada & 665,920 & 466.14 & $3,329.60$ & 143.57 & 516.86 & $20,501.57$ & $66,592.01$ \\
\hline \multicolumn{8}{|l|}{ China } \\
\hline \multicolumn{8}{|l|}{ Cyprus } \\
\hline Czech Republic & 15,230 & 10.66 & 76.15 & 4.52 & 16.27 & 434.97 & $1,422.25$ \\
\hline Denmark & 21,370 & 14.96 & 106.85 & 3.29 & 11.83 & 465.89 & $1,513.28$ \\
\hline \multicolumn{8}{|l|}{ Estonia } \\
\hline Finland & 500 & 0.35 & 2.50 & 0.06 & 0.23 & 8.62 & 28.01 \\
\hline France* & 104,500 & 73.15 & 522.50 & 20.55 & 73.98 & 2,988.34 & $9,706.59$ \\
\hline Germany & 750,000 & 525.00 & $3,750.00$ & 161.21 & 580.37 & $23,445.14$ & $76,153.13$ \\
\hline \multicolumn{8}{|l|}{ Greece } \\
\hline Hungary & 2,800 & 1.96 & 14.00 & 0.80 & 2.87 & 115.88 & 376.40 \\
\hline \multicolumn{8}{|l|}{ India } \\
\hline \multicolumn{8}{|l|}{ I reland } \\
\hline Israel & 24,200 & 16.94 & 121.00 & 1.42 & 5.10 & $1,372.14$ & $4,455.22$ \\
\hline Italy & 26,270 & 18.39 & 131.35 & 5.53 & 19.89 & 827.41 & $2,687.54$ \\
\hline \multicolumn{8}{|l|}{ Japan } \\
\hline \multicolumn{8}{|l|}{ J ordan } \\
\hline \multicolumn{8}{|l|}{ Lativa } \\
\hline \multirow{2}{*}{\multicolumn{8}{|c|}{$\begin{array}{l}\text { Lithuania } \\
\text { Luxemboura }\end{array}$}} \\
\hline \multicolumn{4}{|l|}{ Luxembourg } & & & & \\
\hline \multicolumn{8}{|l|}{ Macedonia } \\
\hline \multicolumn{8}{|l|}{ Malta } \\
\hline Mexico & 467,592 & 327.31 & $2,337.96$ & 135.65 & 488.33 & $20,309.15$ & $65,966.99$ \\
\hline \multicolumn{8}{|l|}{ Namibia } \\
\hline Netherlands & 343,527 & 240.47 & $1,717.64$ & 51.87 & 186.74 & $7,183.48$ & $23,333.04$ \\
\hline New Zealand & 6,217 & 4.35 & 31.08 & 1.40 & 5.05 & 200.76 & 652.09 \\
\hline Norway & 1,600 & 1.12 & 8.00 & 0.23 & 0.82 & 30.24 & 98.22 \\
\hline Poland & 1,300 & 0.91 & 6.50 & 0.27 & 0.98 & 38.13 & 123.86 \\
\hline Portugal & 594 & 0.42 & 2.97 & 0.14 & 0.51 & 21.23 & 68.97 \\
\hline \multicolumn{8}{|l|}{ Romania } \\
\hline \multirow{2}{*}{\multicolumn{8}{|c|}{$\begin{array}{l}\text { Slovak Republic } \\
\text { Slovenia }\end{array}$}} \\
\hline & & & & & & & \\
\hline South Africa & 628,610 & 440.03 & $3,143.05$ & 118.15 & 425.33 & $16,585.50$ & $53,871.88$ \\
\hline Spain & 3,000 & 2.10 & 15.00 & 0.90 & 3.22 & 132.02 & 428.82 \\
\hline Sweden & 80,000 & 56.00 & 400.00 & 10.67 & 38.42 & $1,390.77$ & $4,517.40$ \\
\hline Switzerland ** & 212,400 & 148.68 & $1,062.00$ & 36.82 & 132.55 & $5,099.58$ & $16,564.01$ \\
\hline \multicolumn{8}{|l|}{ Taiwan } \\
\hline Thailand & & & & & & & \\
\hline Tunisia & & & & & & & \\
\hline Turkey & & & & & & & \\
\hline $\begin{array}{l}\text { United King- } \\
\text { dom }\end{array}$ & & & & & & & \\
\hline United States & $27,639,364$ & $19,347.55$ & $138,196.82$ & $7,428.08$ & $26,741.08$ & $1,076,679.81$ & $3,497,222.51$ \\
\hline TOTAL & $35,820,154.05$ & $25,074.11$ & $179,100.77$ & $9,792.55$ & $35,253.18$ & $1,423,913.57$ & $4,625,097.08$ \\
\hline
\end{tabular}

* France: includes Overseas Departments

** Unglazed Water Collectors. If no data is given: no reliable data base for this collector type available

Table 5: Calculated collector yield and corresponding oil equivalent as well as $\mathrm{CO}_{2}$ reduction of solar thermal systems for swimming pool heating with unglazed collectors at the end of 2007 


\subsection{Collector yield by economic region at the end of 2007}

\subsubsection{Collector yield of glazed flat-plate and evacuated tube collectors by economic region at the end of 2007}

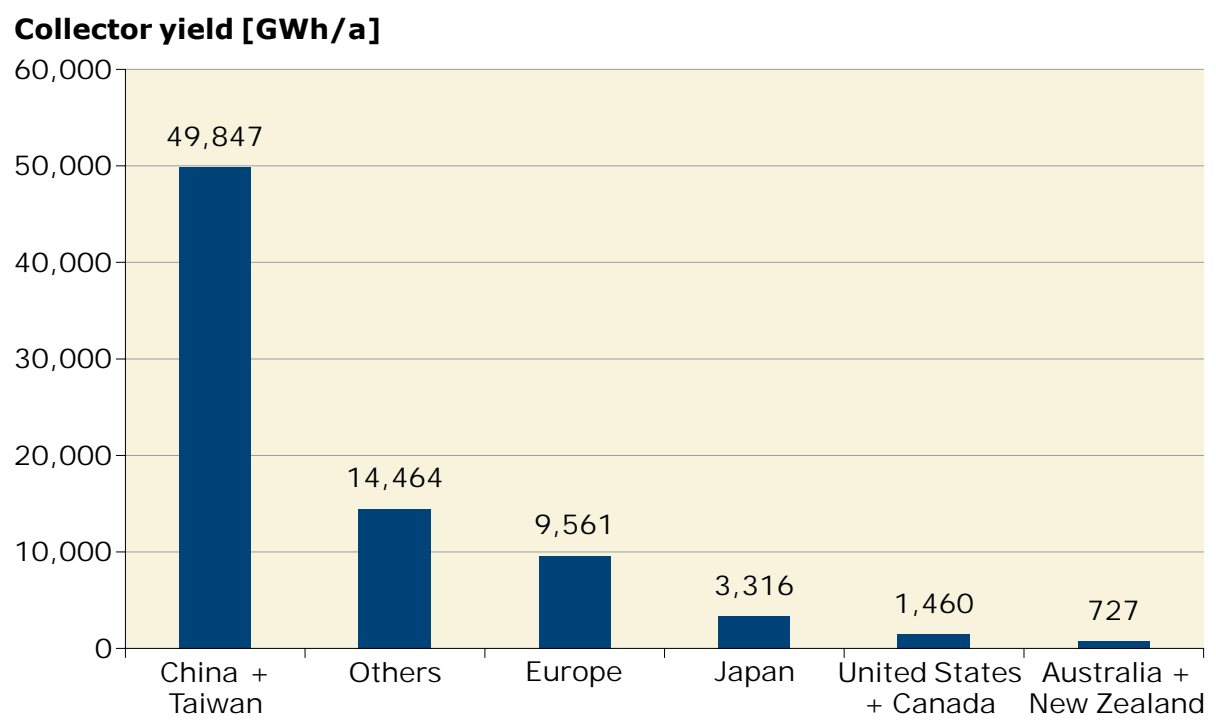

Europe: EU-27, Albania, Macedonia, Norway, Overseas Departments of France, Switzerland; Others: Barbados, Brazil, India, Israel, Jordan, Mexico, Namibia, South Africa, Tunisia and Turkey

Figure 16: Annual collector yield of glazed flat-plate and evacuated tube collectors in operation by economic region at the end of 2007

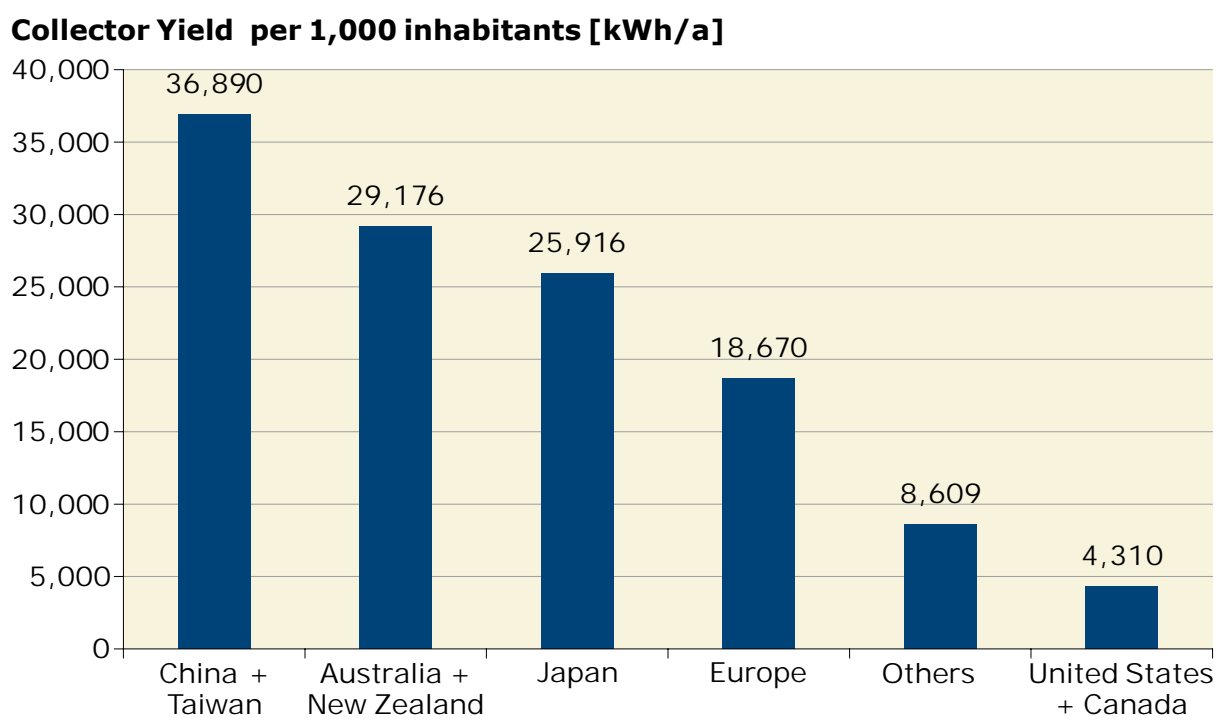

Europe: EU-27, Albania, Macedonia, Norway, Overseas Departments of France, Switzerland; Others: Barbados, Brazil, India, Israel, Jordan, Mexico, Namibia, South Africa, Tunisia and Turkey

Figure 17: Annual collector yield of glazed flat-plate and evacuated tube collectors in operation by economic region at the end of 2007 in kWh per 1,000 inhabitants 


\subsubsection{Collector yield of unglazed collectors by economic region at the end of $\mathbf{2 0 0 7}$}

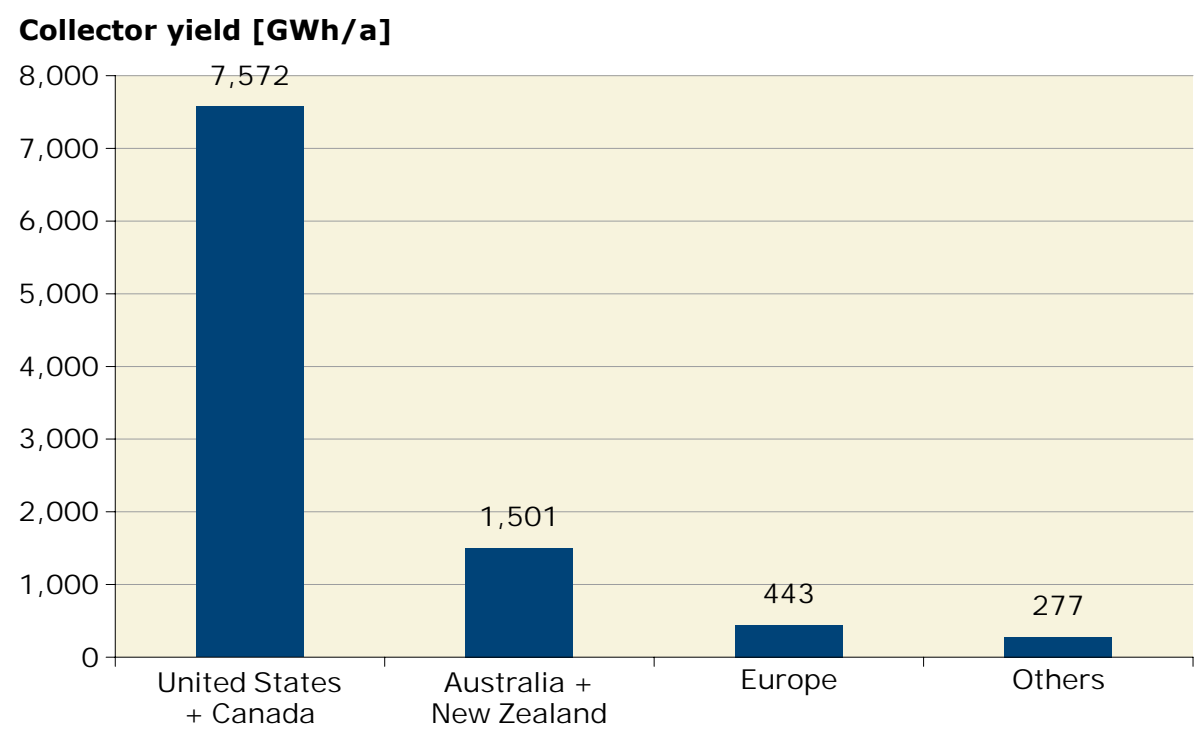

Europe: EU-27, Albania, Macedonia, Norway, Overseas Departments of France, Switzerland; Others: Barbados, Brazil, India, Israel, Jordan, Mexico, Namibia, South Africa, Tunisia and Turkey

Figure 18: Annual collector yield of unglazed collectors in operation by economic region at the end of 2007

\section{Collector yield per 1,000 inhabitants [ $\mathrm{kWh} / \mathrm{a}]$}

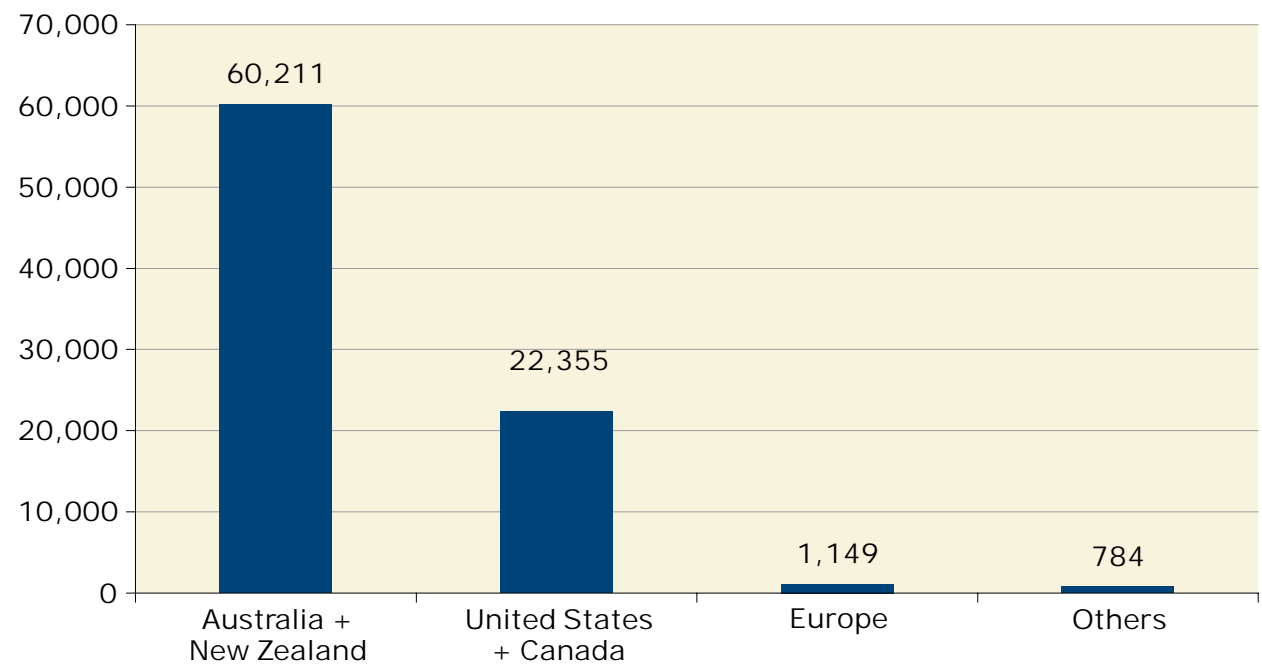

Europe: EU-27, Albania, Macedonia, Norway, Overseas Departments of France, Switzerland; Others: Barbados, Brazil, India, Israel, Jordan, Mexico, Namibia, South Africa, Tunisia and Turkey

Figure 19: Annual collector yield of unglazed collectors in operation by economic region at the end of 2007 in kWh per 1,000 inhabitants 


\subsection{Energy savings by economic region at the end of 2007}

\subsubsection{Energy savings in oil equivalent by glazed flat-plate and evacuated tube collectors by economic region at the end of 2007}

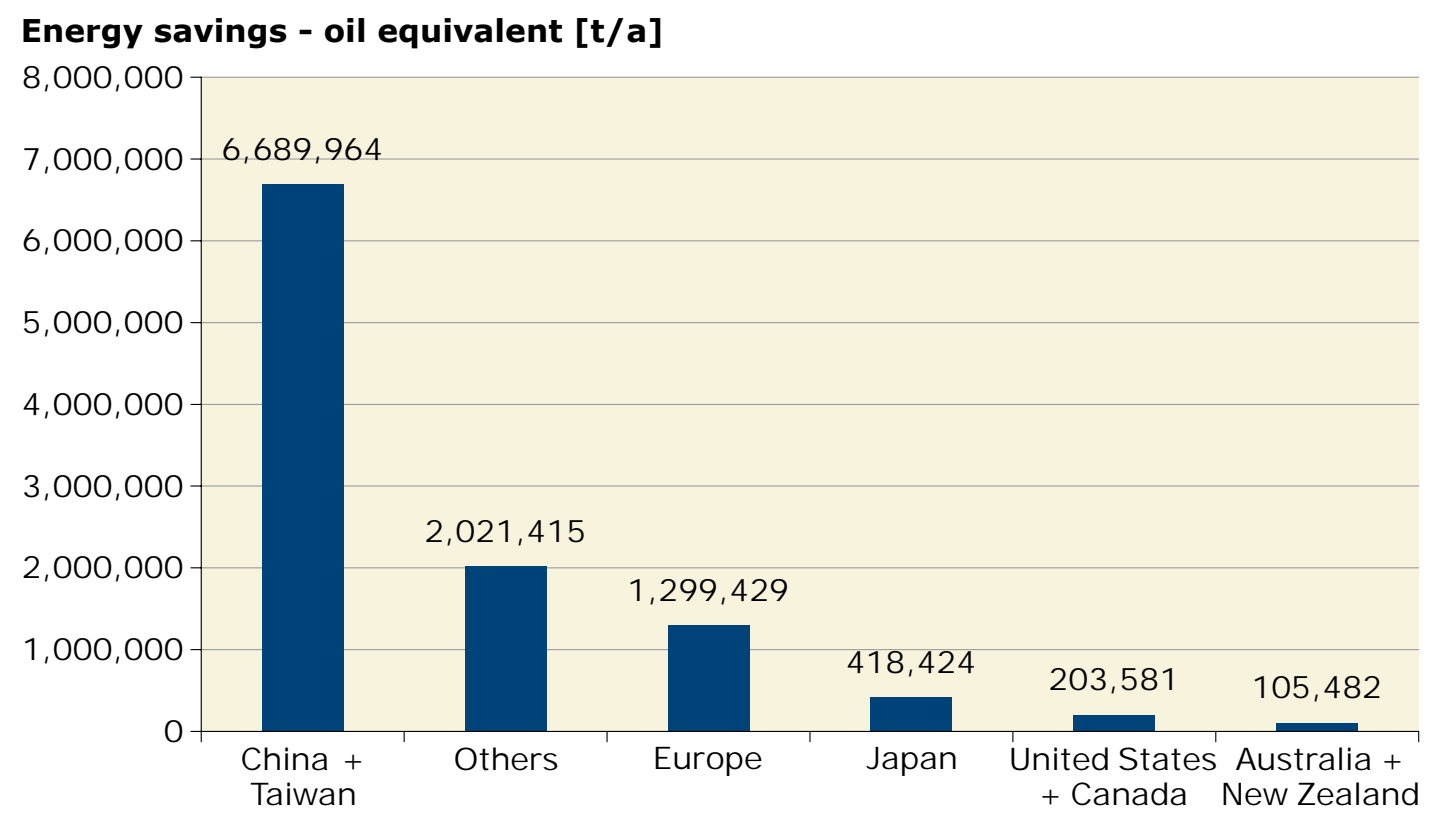

Europe: EU-27, Albania, Macedonia, Norway, Overseas Departments of France, Switzerland; Others: Barbados, Brazil, India, Israel, J ordan, Mexico, Namibia, South Africa, Tunisia and Turkey

Figure 20: Annual energy savings in oil equivalent by glazed flat-plate and evacuated tube collectors by economic region at the end of 2007

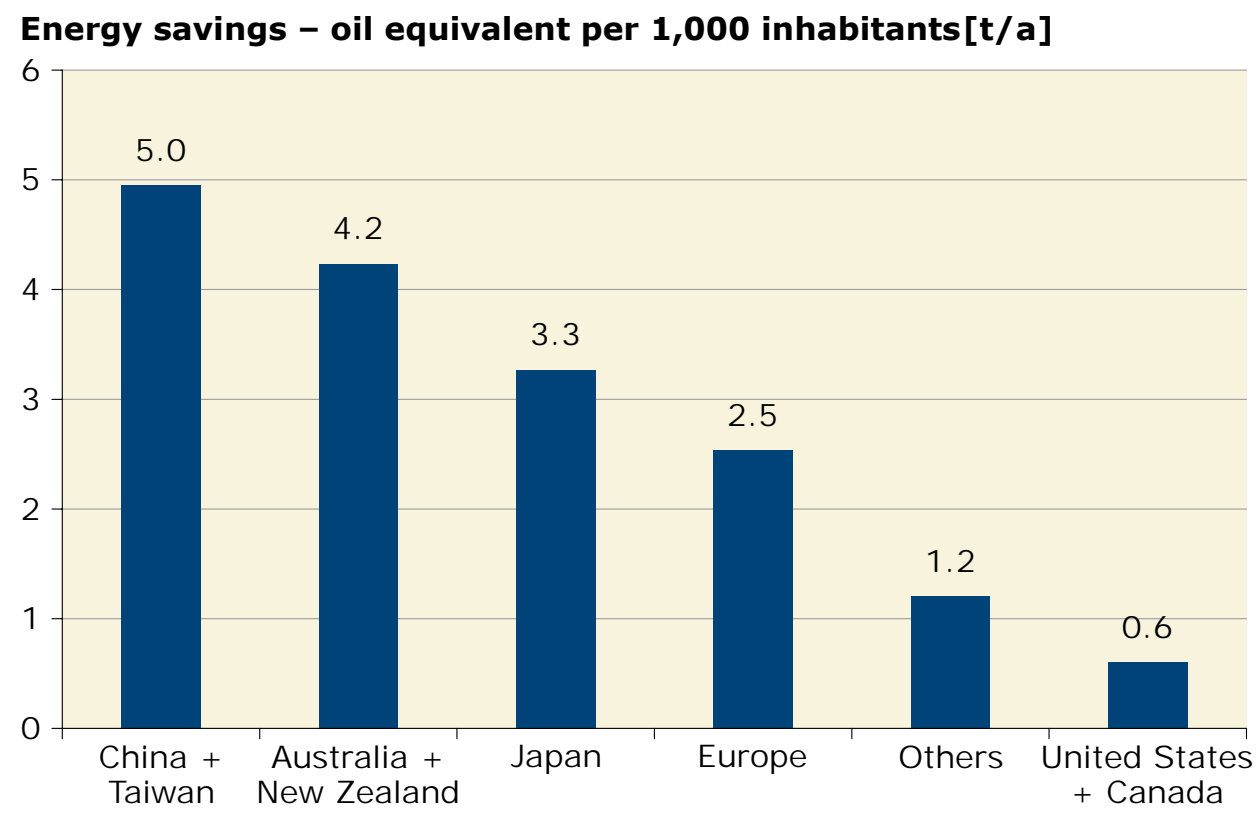

Europe: EU-27, Albania, Macedonia, Norway, Overseas Departments of France, Switzerland; Others: Barbados, Brazil, India, Israel, Jordan, Mexico, Namibia, South Africa, Tunisia and Turkey

Figure 21: Annual energy savings in oil equivalent by glazed flat-plate and evacuated tube collectors in operation by economic region at the end of 2007 per 1,000 inhabitants 


\subsubsection{Energy savings in oil equivalent by unglazed collectors by economic region at the end of 2007}

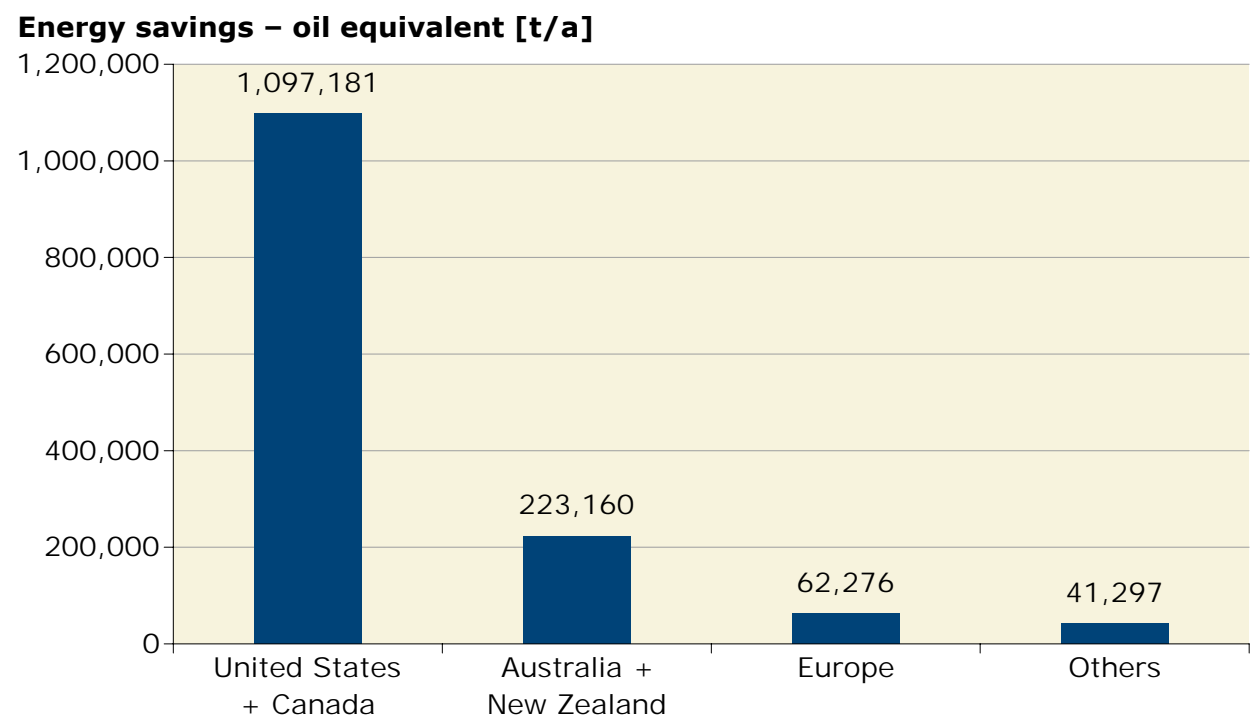

Europe: EU-27, Albania, Macedonia, Norway, Overseas Departments of France, Switzerland; Others: Barbados, Brazil, India, Israel, Jordan, Mexico, Namibia, South Africa, Tunisia and Turkey

Figure 22: Annual energy savings in oil equivalent by unglazed collectors by economic region at the end of 2007

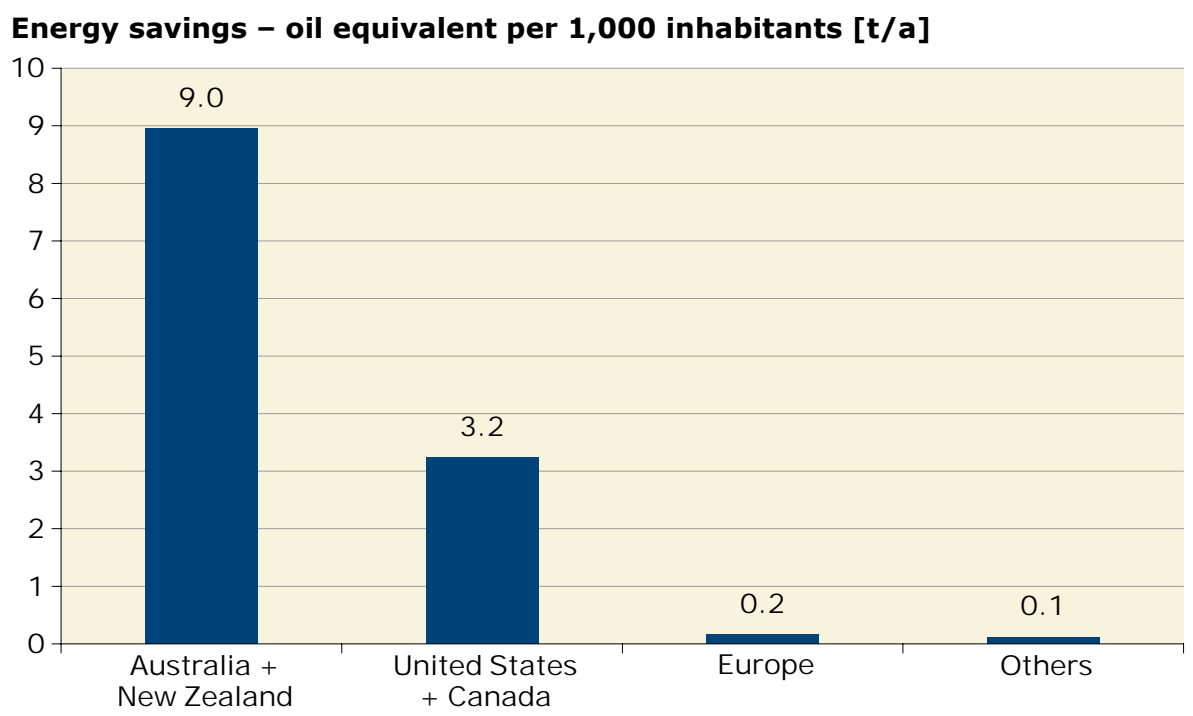

Europe: EU-27, Albania, Macedonia, Norway, Overseas Departments of France, Switzerland; Others: Barbados, Brazil, India, Israel, J ordan, Mexico, Namibia, South Africa, Tunisia and Turkey

Figure 23: Annual energy savings in oil equivalent by unglazed collectors by economic region at the end of 2007 per 1,000 inhabitants 


\subsection{Contribution to $\mathrm{CO}_{2}$ reduction by economic region at the end of 2007}

\subsubsection{Contribution to $\mathrm{CO}_{2}$ reduction by flat-plate and evacuated tube collectors by economic region at the end of 2007}

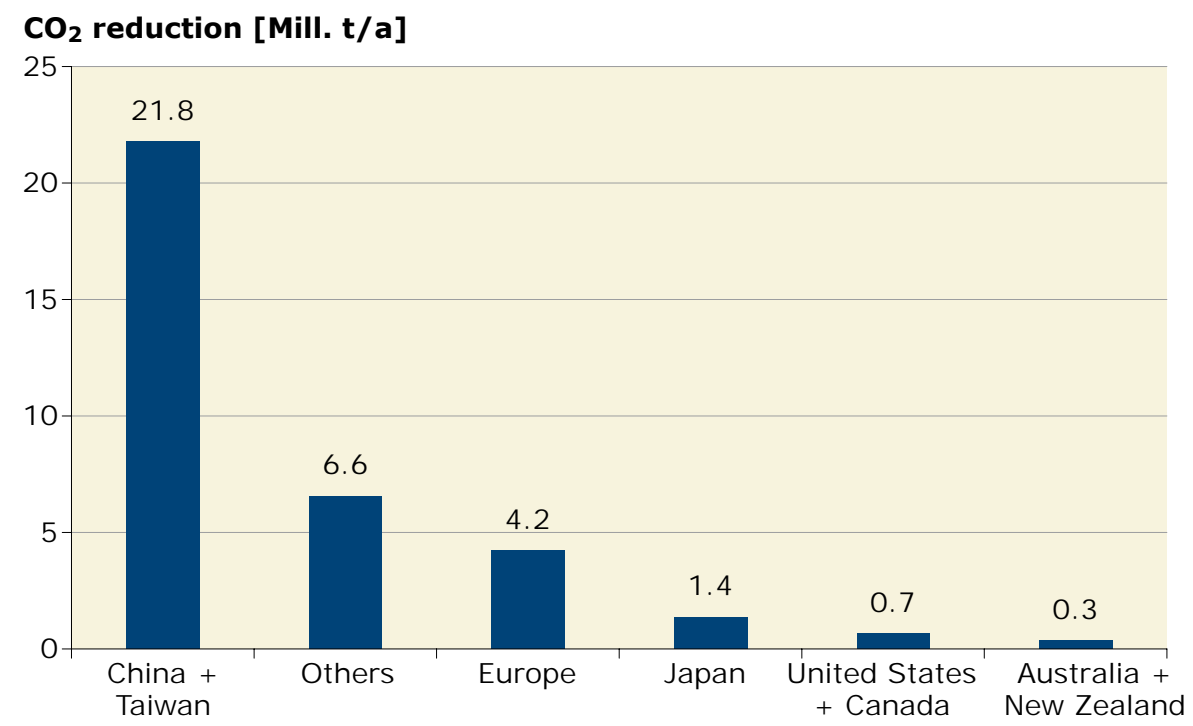

Europe: EU-27, Albania, Macedonia, Norway, Overseas Departments of France, Switzerland;

Others: Barbados, Brazil, India, Israel, J ordan, Mexico, Namibia, South Africa, Thailand, Tunisia and Turkey

Figure 24: Annual contribution to $\mathrm{CO}_{2}$ reduction by flat-plate and evacuated tube collectors

by economic region the end of 2007

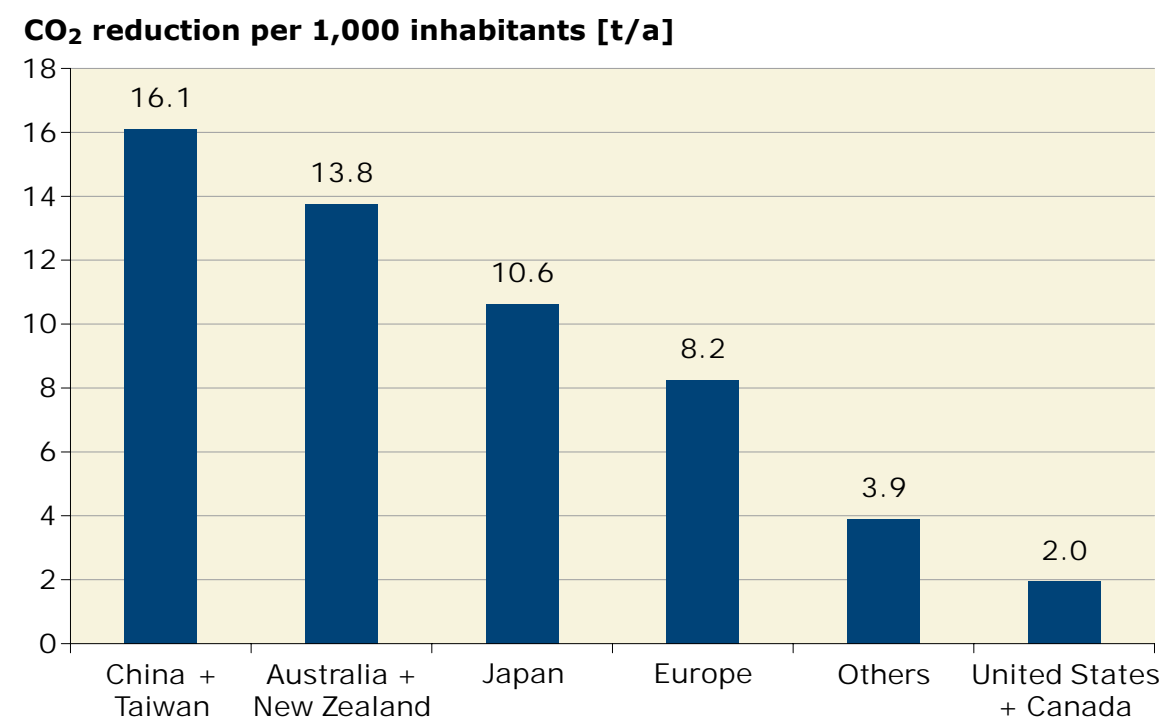

Europe: EU-27, Albania, Macedonia, Norway, Overseas Departments of France, Switzerland;

Others: Barbados, Brazil, India, Israel, J ordan, Mexico, Namibia, South Africa, Thailand, Tunisia and Turkey

Figure 25: Annual contribution to $\mathrm{CO}_{2}$ reduction by flat-plate and evacuated tube collectors by economic region at the end of 2007 per 1,000 inhabitants 


\subsubsection{Contribution to $\mathrm{CO}_{2}$ reduction by unglazed collectors by economic region at the end of 2007}

$\mathrm{CO}_{2}$ reduction [Mill. $\mathrm{t} / \mathrm{a}$ ]

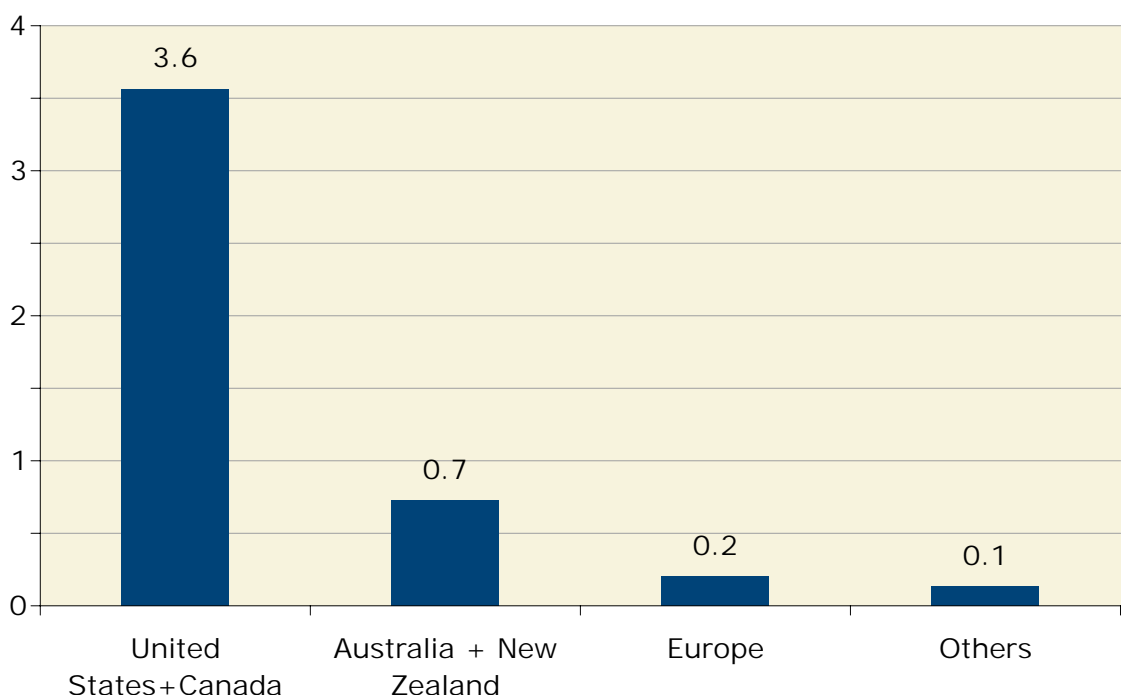

Europe: EU-27, Albania, Macedonia, Norway, Overseas Departments of France, Switzerland;

Others: Barbados, Brazil, India, Israel, Jordan, Mexico, Namibia, South Africa, Thailand, Tunisia and Turkey

Figure 26: Annual contribution to $\mathrm{CO}_{2}$ reduction by unglazed collectors by economic region at the end of 2007

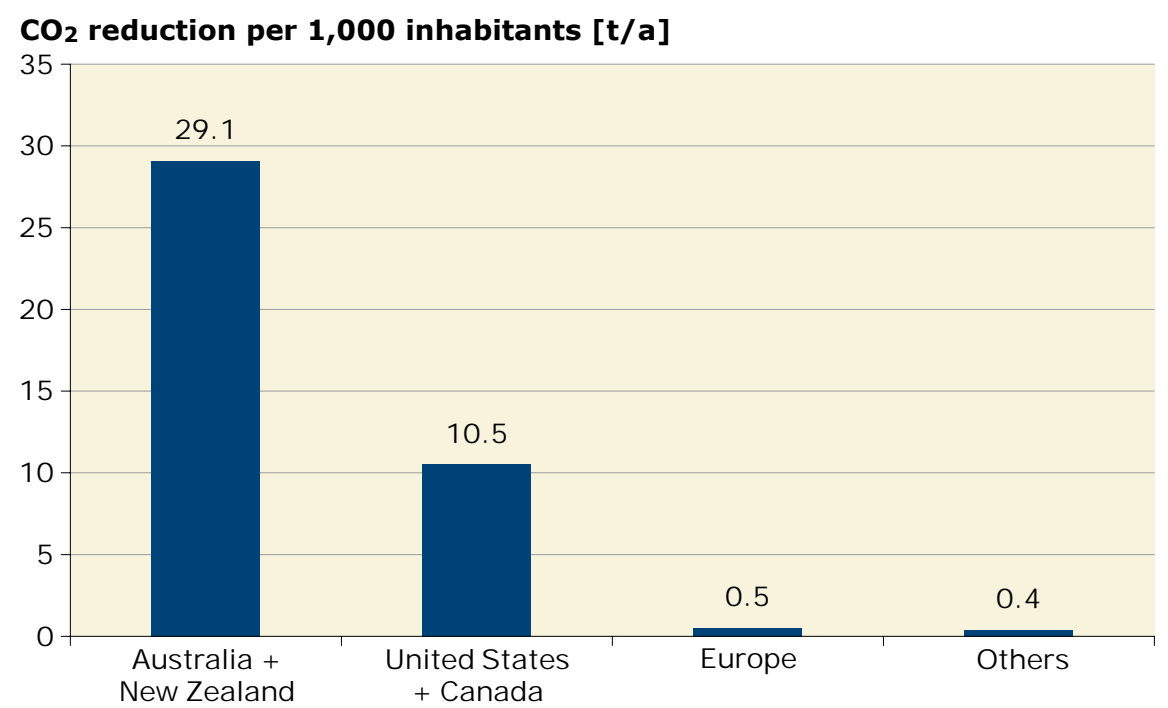

Europe: EU-27, Albania, Macedonia, Norway, Overseas Departments of France, Switzerland; Others: Barbados, Brazil, India, Israel, Jordan, Mexico, Namibia, South Africa, Thailand, Tunisia and Turkey

Figure 27: Annual contribution to $\mathrm{CO}_{2}$ reduction by unglazed collectors by economic region at the end of 2007 per 1,000 inhabitants 


\section{Distribution of systems by application}

\subsection{Distribution by application - total capacity in operation}

If one observes the use of solar thermal energy, it becomes clear that it greatly varies in the different countries. In China and Taiwan (76.5 $\mathrm{GW}_{\mathrm{th}}$ ), Europe $\left(15.9 \mathrm{GW}_{\mathrm{th}}\right.$ ) and Japan $\left(4.9 \mathrm{GW}_{\mathrm{th}}\right.$ ) plants with flat-plate and evacuated tube collectors mainly used to prepare hot water and to provide space heating are dominant while in North America (USA and Canada) swimming pool heating is the dominant application with an installed capacity of $19.8 \mathrm{GW}_{\text {th }}$ of unglazed plastic collectors. Another important market for unglazed collectors for swimming pool heating is Australia and New Zealand with an installed capacity of $2.9 \mathrm{GW}_{\text {th. }}$

Figure $\mathbf{2 8}$ shows the distribution of the different applications in the total collector area in operation in the different economic regions. In this figure only applications with glazed flat-plate and evacuated tube collectors have been taken into consideration. Unglazed collectors and air collectors are not included. The figure shows the dominance of systems that are installed to prepare hot water for single-family houses. The share of solar combisystems for hot water production and space heating is only relevant in Europe and J apan. Figure $\mathbf{2 9}$ gives the distribution of the applications for the 10 countries in the world with the largest collector area in operation.

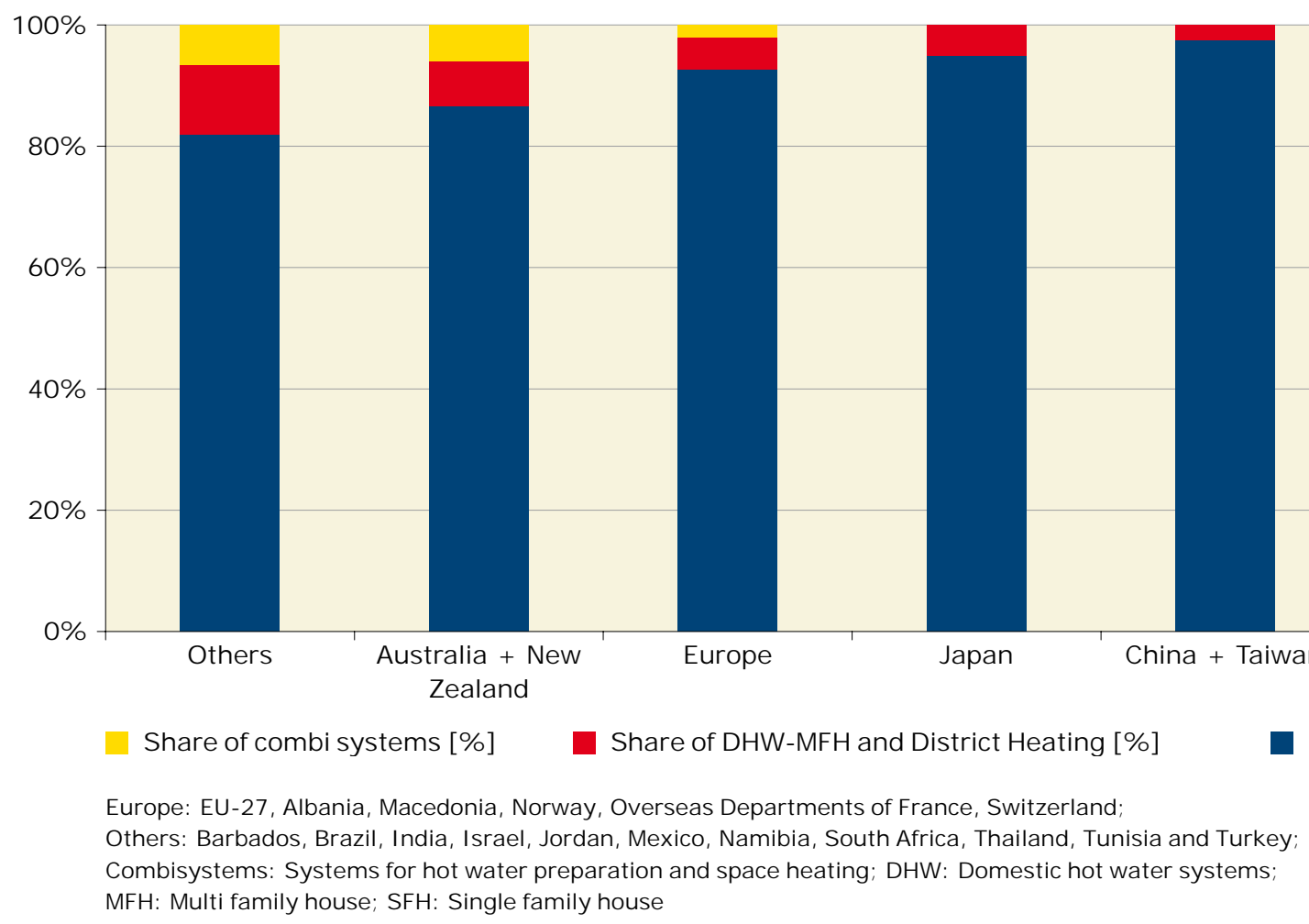

Figure 28: Distribution of different applications by economic region for the total capacity in operation of glazed and evacuated tube collectors in 2007

Europe has the most sophisticated market for different solar thermal applications. It includes systems for hot water preparation, plants for space heating of single- and multi-family houses and hotels, large-scale plants for district heating as well as a growing number of systems for air conditioning, cooling and industrial applications.

In Austria, Germany, Switzerland and the Netherlands the share of applications other than hot water preparation in single-family houses is $20 \%$ and higher. Figure $\mathbf{3 0}$ gives the distribution of the applications for the 10 countries in Europe with the largest collector area in operation. 


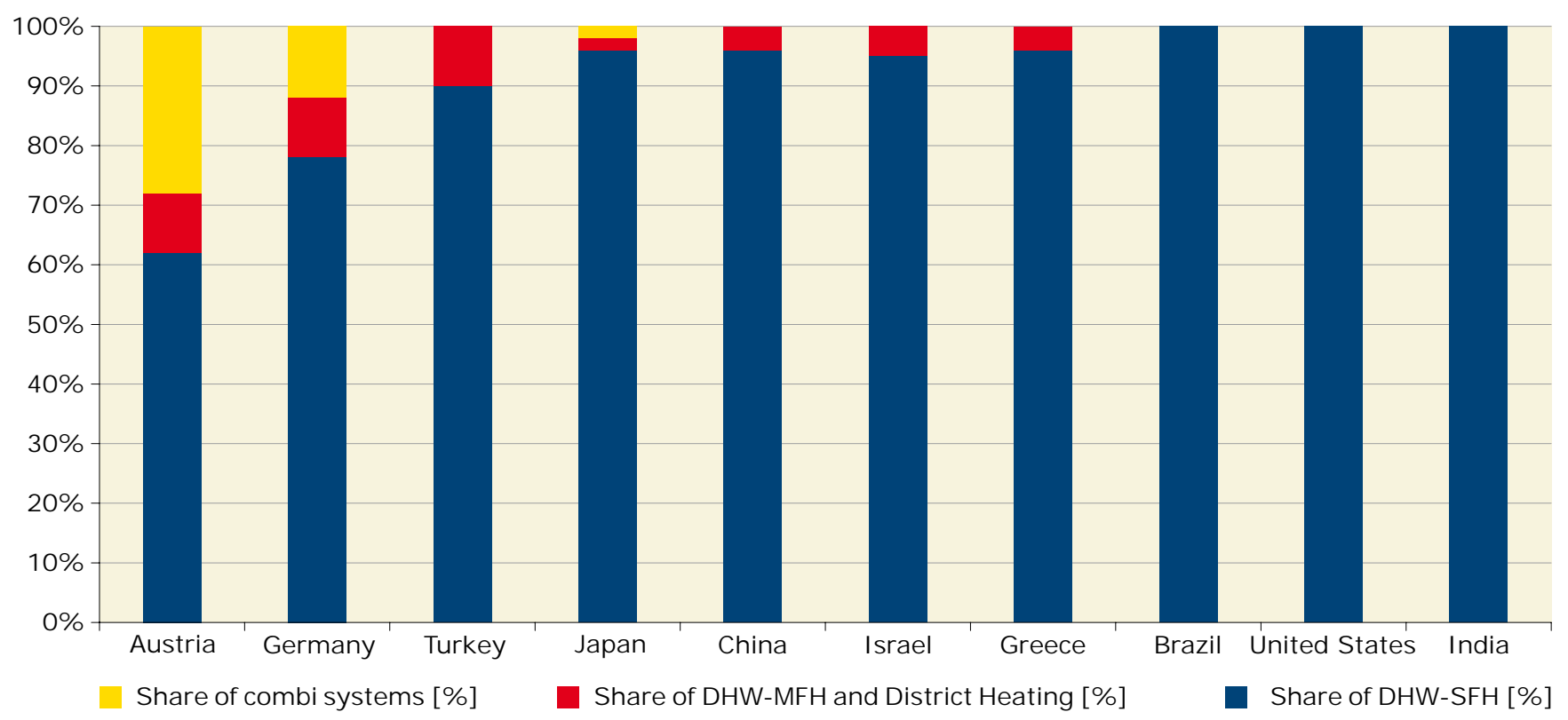

Combisystems: Systems for hot water preparation and space heating; DHW: Domestic hot water systems; MFH: Multi-family house; SFH: Single-family house

Figure 29: Distribution of different applications of the world's top-10-countries related to the total capacity in operation of glazed and evacuated tube collectors in 2007

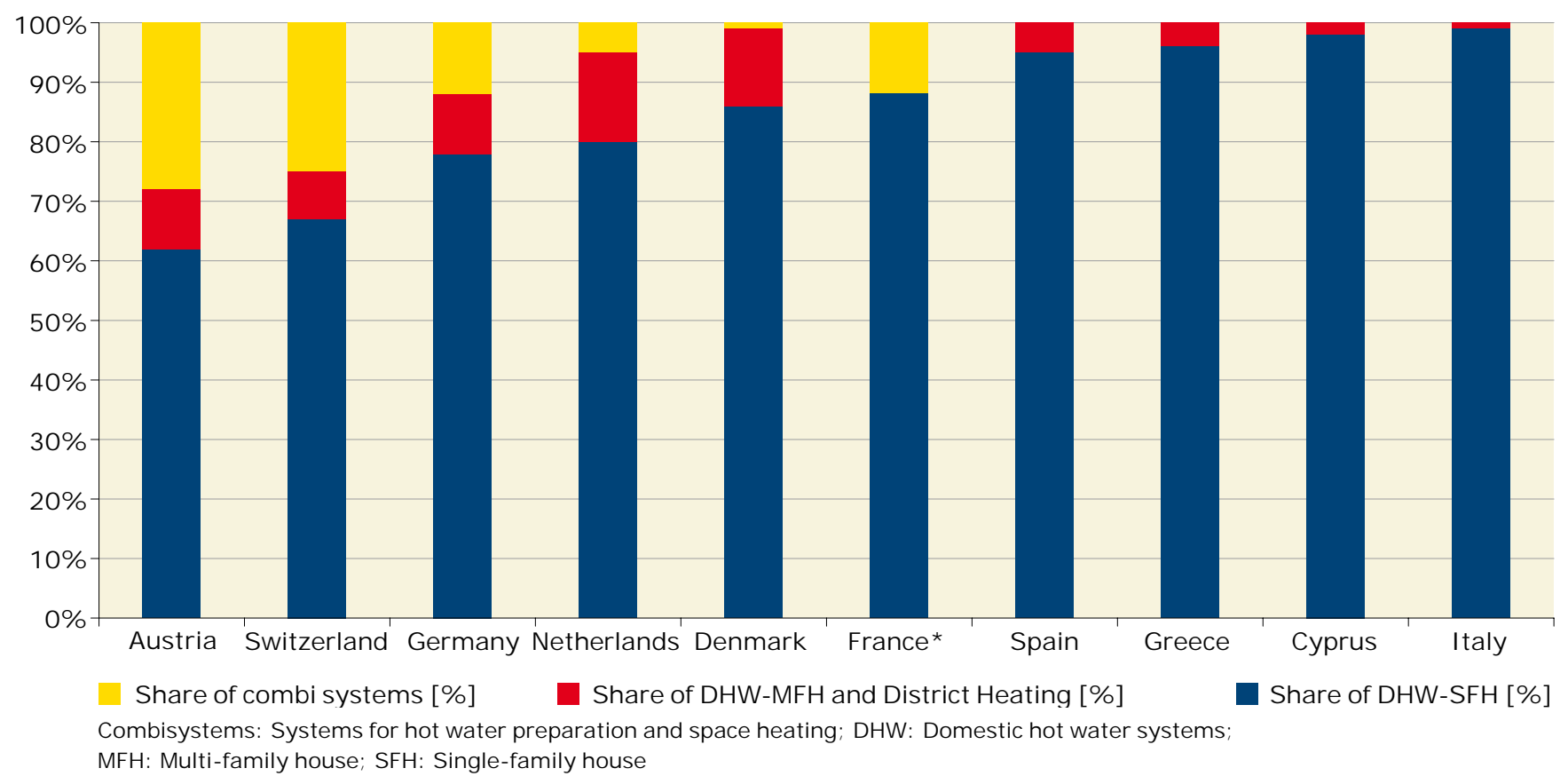

Figure 30: Distribution of different applications in the European top-10-countries related to the total capacity in operation of glazed and evacuated tube collectors in 2007 


\section{Large-scale Plants}

There are 130 large-scale plants $\left(\geq 500 \mathrm{~m}^{2} ; 350 \mathrm{~kW}_{\mathrm{th}}\right)$ in operation in Europe at the end of 2007 with a total installed capacity of $137 \mathrm{MW}_{\text {th }}$. The biggest plants are located in Denmark with $13 \mathrm{MW}_{\text {th }}\left(18,300 \mathrm{~m}^{2}\right)$ and Sweden with $7 \mathrm{MW}_{\text {th }}$ $\left(10,000 \mathrm{~m}^{2}\right)$.

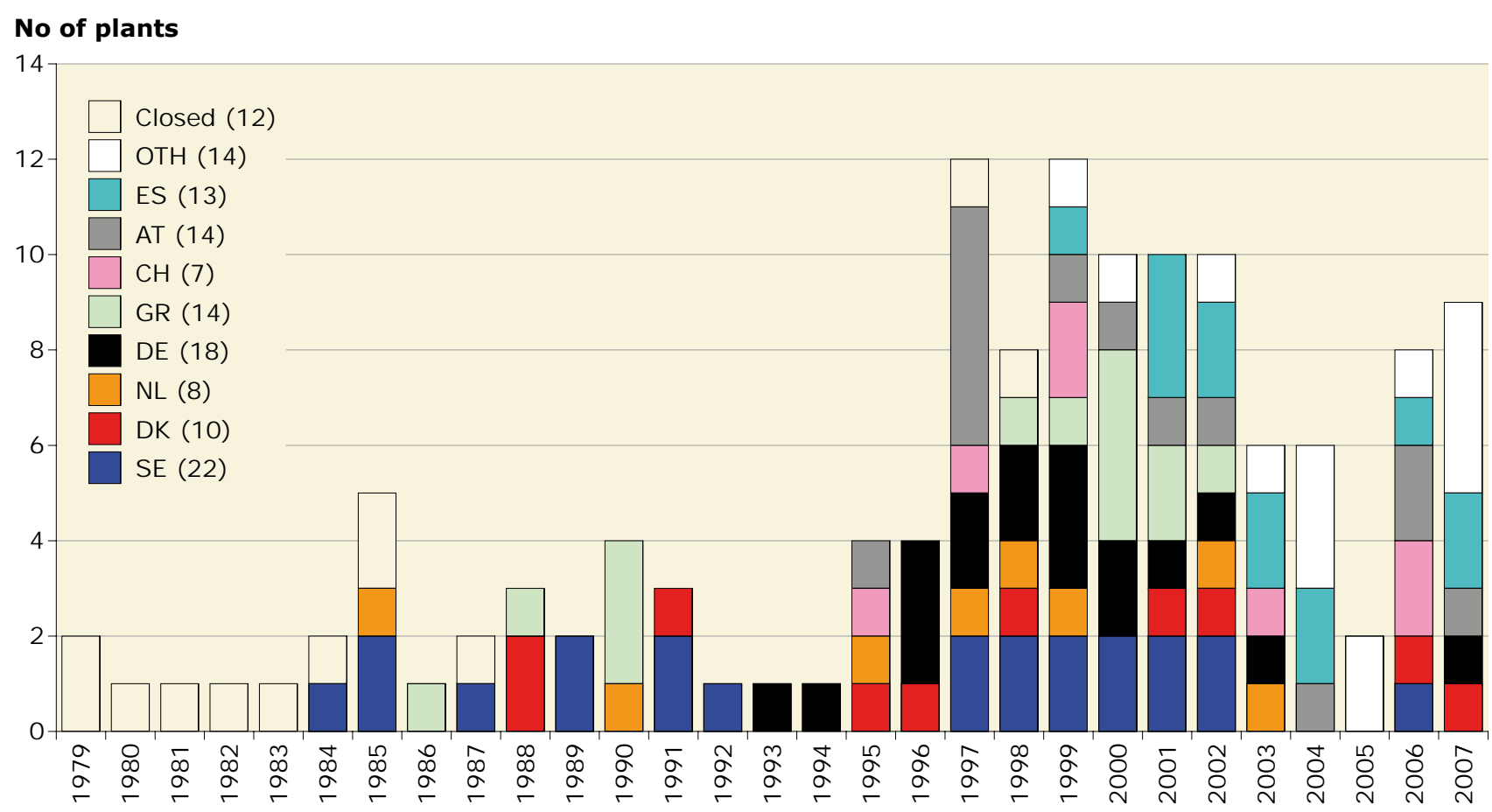

(Source: J an-Olof Dalenbäck, ESTTP report on solar district heating and cooling, 2007)

Figure 31: Large-scale solar heating and cooling plants in Europe at the end of 2007

Most of these large-scale solar thermal systems are connected to district heating. The heat is used for hot water preparation and space heating. In recent years also large-scale solar heating systems were installed in order to provide heat for industrial applications and air conditioning. 


\subsection{Distribution by application - systems installed in 2007}

In this chapter the distribution of solar thermal systems in different applications of the collector area, which were installed in 2007 is presented. Figure $\mathbf{3 2}$ shows the distribution of the different applications in the different economic regions. In this figure only applications with glazed flat-plate and evacuated tube collectors have been taken into consideration. Unglazed collectors and air collectors are not included. The figure shows the dominance of systems that are installed to prepare hot water for single-family houses. The share of solar combisystems ( hot water preparation and space heating) for different applications is only relevant in Europe, China and Taiwan.

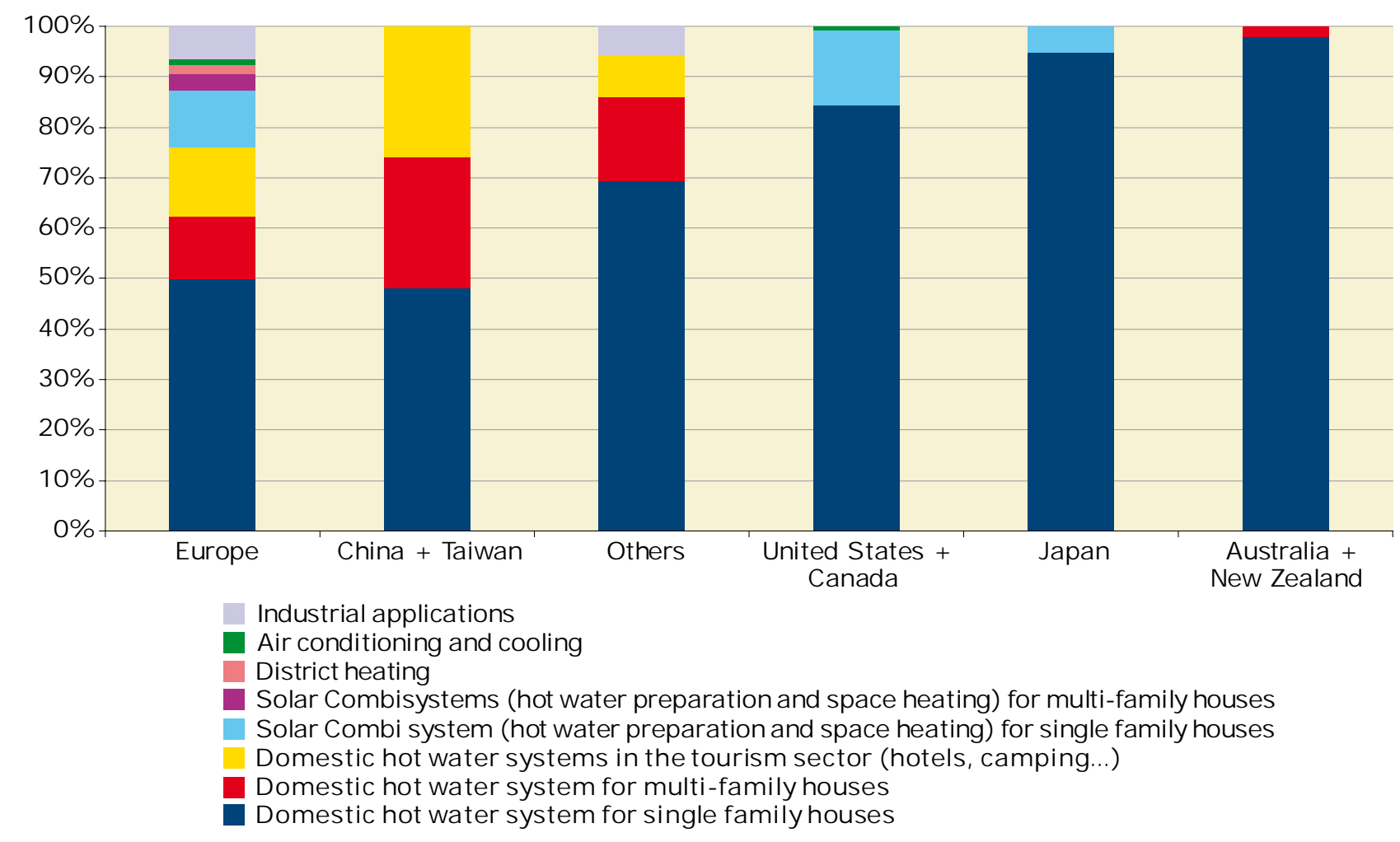

Europe: EU-27, Albania, Macedonia, Norway, Overseas Departments of France, Switzerland;

Others: Barbados, Brazil, India, Israel, Jordan, Mexico, Namibia, South Africa, Thailand, Tunisia and Turkey; Combisystems: Systems for hot water preparation and space heating; DHW: Domestic hot water systems; MFH: Multi family house; SFH: Single family house

Figure 32: Distribution of different solar thermal applications by economic region, which were installed in the year 2007 


\section{$7 \quad$ Appendix}

\subsection{Reference systems}

To make the simulations to determine the energy output of a solar thermal heating system, it was necessary to define reference systems for different applications and countries (regions).

Based on the reference systems, hot water demand, heat load (only for solar combisystems) and weather data, the energy output of the systems and the resulting energy savings in oil equivalent were calculated.

Solar combisystems are solar heating installations providing space heating as well as domestic hot water for the inhabitants of the building. The primary energy sources are solar energy as well as an auxiliary source such as biomass, gas, oil and electricity.

Four major applications and reference systems (see tables below) were chosen for the simulations. For these reference systems, the daily hot water demand, the space heating demand (only for solar combisystems) and the weather data (location) were defined. The reference systems are those systems, which are most common in the respective country.

The following tables describe the key data of the reference systems in different countries, the location of the reference climate used and the share of the total collector area ( glazed flat-plate and evacuated tube collectors) in use for the respective application. Furthermore, a hydraulic scheme is shown for each reference system.

\subsubsection{Solar thermal systems for swimming pool heating with unglazed collectors}

\begin{tabular}{|l|l|r|r|l|}
\hline Country & \multicolumn{1}{c|}{ Reference system } & Total collector area [ $\mathrm{m}^{2}$ ] & Number of systems & \multicolumn{1}{c|}{ Reference climate } \\
\hline Australia & C: $200 \mathrm{~m}^{2}$ unglazed plastic absorber & $4,070,000$ & 20,350 & Sydney \\
\hline Austria & C: $200 \mathrm{~m}^{2}$ unglazed plastic absorber & 608,890 & 3,044 & Graz \\
\hline Belgium & C: $200 \mathrm{~m}^{2}$ unglazed plastic absorber & 48,828 & 244 & Brussels \\
\hline Canada & C: $200 \mathrm{~m}^{2}$ unglazed plastic absorber & 665,920 & 3,330 & Montreal \\
\hline Czech Republic & C: $200 \mathrm{~m}^{2}$ unglazed plastic absorber & 15,230 & 76 & Praha \\
\hline Denmark & C: $200 \mathrm{~m}^{2}$ unglazed plastic absorber & 21,370 & 107 & Copenhagen \\
\hline Finland & C: $200 \mathrm{~m}^{2}$ unglazed plastic absorber & 500 & 3 & Helsinki \\
\hline France* & C: $200 \mathrm{~m}^{2}$ unglazed plastic absorber & 104,500 & 523 & Paris \\
\hline Germany & C: $200 \mathrm{~m}^{2}$ unglazed plastic absorber & 750,000 & 3,750 & Würzburg \\
\hline Hungary & C: $200 \mathrm{~m}^{2}$ unglazed plastic absorber & 2,800 & 14 & Budapest \\
\hline Israel & C: $200 \mathrm{~m}^{2}$ unglazed plastic absorber & 24,200 & 121 & Jerusalem \\
\hline Italy & C: $200 \mathrm{~m}^{2}$ unglazed plastic absorber & 26,270 & 131 & Bologna \\
\hline Mexico & C: $200 \mathrm{~m}^{2}$ unglazed plastic absorber & 467,592 & 2,338 & Mexico City \\
\hline Netherlands & C: $200 \mathrm{~m}^{2}$ unglazed plastic absorber & 343,527 & 1,718 & De Bilt \\
\hline New Zealand & C: $200 \mathrm{~m}^{2}$ unglazed plastic absorber & 6,217 & 31 & Wellington \\
\hline Norway & C: $200 \mathrm{~m}^{2}$ unglazed plastic absorber & 1,600 & 8 & Oslo \\
\hline Poland & C: $200 \mathrm{~m}^{2}$ unglazed plastic absorber & 1,300 & 7 & Warsaw \\
\hline South Africa & C: $200 \mathrm{~m}^{2}$ unglazed plastic absorber & 628,610 & 3,143 & Johannisburg \\
\hline Sweden & C: $200 \mathrm{~m}^{2}$ unglazed plastic absorber & 80,000 & 400 & Gothenburg \\
\hline Switzerland & C: $200 \mathrm{~m}^{2}$ unglazed plastic absorber & 212,400 & 1,062 & Zurich \\
\hline United States & C: $200 \mathrm{~m}^{2}$ unglazed plastic absorber & $27,639,364$ & 138,197 & Denver, Los Angeles \\
\hline TOTAL & & $\mathbf{3 5 , 7 1 9 , 1 1 8}$ & $\mathbf{1 7 8 , 5 9 6}$ & \\
\hline
\end{tabular}

C: collector area

* France: includes Overseas Departments

** Countries not listed in this table: no reliable data base for unglazed collectors available

Table 6: Reference systems for swimming pool systems**

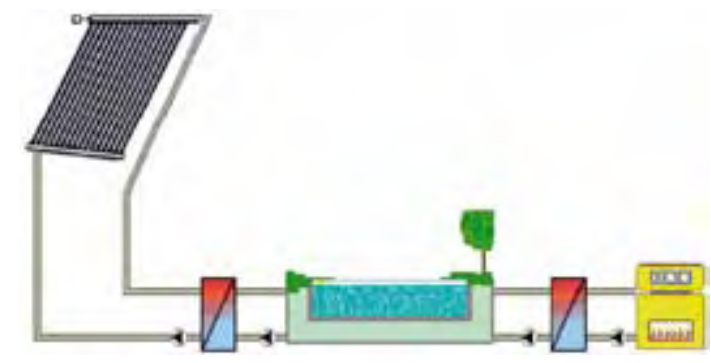

Figure 33: Hydraulic scheme of the swimming pool reference system 


\subsubsection{Solar domestic hot water systems for single family houses}

The market share in the following table is referring to the total capacity in operation of flat-plate and evacuated tube collectors at the end of 2007 for each country.

It must be pointed out that the market share of the new installed capacity in the year 2007 can differ significantly from the total market share.

\begin{tabular}{|c|c|c|c|}
\hline Country & $\begin{array}{l}\text { reference system } \\
\end{array}$ & reference climate & $\%$ of total market \\
\hline Albania & C: $2.5 \mathrm{~m}^{2}$ / ST: $150 \mathrm{l} / \mathrm{HWD}: 150 \mathrm{l} / \mathrm{d} / \mathrm{TS}$ & Tirana & 100 \\
\hline Australia & C: 4 m² / ST: 300 l/ HWD: 170 l/d / TS & Sydney & 98 \\
\hline Austria & C: $6 \mathrm{~m}^{2} / \mathrm{ST}: 300$ I / HWD: $150 \mathrm{l} / \mathrm{d} / \mathrm{PS}$ & Graz & 63 \\
\hline Barbados & C: $4 \mathrm{~m}^{2} / \mathrm{ST}: 200 \mathrm{l} / \mathrm{HWD}: 150 \mathrm{l} / \mathrm{d} / \mathrm{TS}$ & Raizet & 100 \\
\hline Belgium & C: $4 \mathrm{~m}^{2} / \mathrm{ST}: 200$ I / HWD: $150 \mathrm{l} / \mathrm{d} / \mathrm{PDS}$ & Brussels & 100 \\
\hline Brazil & C: $4 \mathrm{~m}^{2} / \mathrm{ST}: 200 \mathrm{l} / \mathrm{HWD}: 150 \mathrm{l} / \mathrm{d} / \mathrm{TS}$ & Rio de J aneiro & 100 \\
\hline Bulgaria & C: $4 \mathrm{~m}^{2} / \mathrm{ST}: 200$ I / HWD: $150 \mathrm{l} / \mathrm{d} / \mathrm{PS}$ & Sofia & 100 \\
\hline Canada & C: $6 \mathrm{~m}^{2} / \mathrm{ST}: 300 \mathrm{l} / \mathrm{HWD}: 150 \mathrm{l} / \mathrm{d} / \mathrm{PS}$ & Montreal & 95 \\
\hline China & C: $4 \mathrm{~m}^{2} / \mathrm{ST}: 200$ I / HWD: $150 \mathrm{l} / \mathrm{d} / \mathrm{TS}$ & Shanghai & 97 \\
\hline Cyprus & C: $4 \mathrm{~m}^{2} / \mathrm{ST}: 200$ I / HWD: $150 \mathrm{l} / \mathrm{d} / \mathrm{TS}$ & Cyprus & 98 \\
\hline Czech Republic & C: $6 \mathrm{~m}^{2} / \mathrm{ST}: 300$ I / HWD: $150 \mathrm{l} / \mathrm{d} / \mathrm{PS}$ & Prague & 99 \\
\hline Denmark & C: $4 \mathrm{~m}^{2} / \mathrm{ST}: 200 \mathrm{l} / \mathrm{HWD}: 150 \mathrm{l} / \mathrm{d} / \mathrm{PS}$ & Copenhagen & 86 \\
\hline Estonia & C: $4 \mathrm{~m}^{2} / \mathrm{ST}: 200$ I / HWD: $150 \mathrm{l} / \mathrm{d} / \mathrm{PS}$ & Tallinn & 100 \\
\hline Finland & C: $4 \mathrm{~m}^{2} / \mathrm{ST}: 200$ I / HWD: $150 \mathrm{l} / \mathrm{d} / \mathrm{PS}$ & Helsinki & 95 \\
\hline France & C: $4 \mathrm{~m}^{2} / \mathrm{ST}: 200$ l / HWD: $150 \mathrm{l} / \mathrm{d} / \mathrm{PS}$ & Paris & 95 \\
\hline Germany & C: 6 m² / ST: 300 I / HWD: 150 l/d / PS & Würzburg & 80 \\
\hline Greece & C: $2.5 \mathrm{~m}^{2} / \mathrm{ST}: 150$ I / HWD: $150 \mathrm{l} / \mathrm{d} / \mathrm{TS}$ & Athens & 98 \\
\hline Hungary & C: $6 \mathrm{~m}^{2} / \mathrm{ST}: 300 \mathrm{l} / \mathrm{HWD}: 150 \mathrm{l} / \mathrm{d} / \mathrm{PS}$ & Budapest & 99 \\
\hline India & C: $4 \mathrm{~m}^{2} / \mathrm{ST}: 200$ I / HWD: $150 \mathrm{l} / \mathrm{d} / \mathrm{TS}$ & Mumbay & 100 \\
\hline I reland & C: $4 \mathrm{~m}^{2} / \mathrm{ST}: 200 \mathrm{l} / \mathrm{HWD}: 150 \mathrm{l} / \mathrm{d} / \mathrm{PS}$ & Dublin & 100 \\
\hline Israel & C: $4 \mathrm{~m}^{2} / \mathrm{ST}: 200$ I / HWD: $150 \mathrm{l} / \mathrm{d} / \mathrm{TS}$ & Jerusalem & 98 \\
\hline Italy & C: $4 \mathrm{~m}^{2} /$ ST: 200 l / HWD: $150 \mathrm{l} / \mathrm{d} / \mathrm{PS}$ & Bologna & 100 \\
\hline Japan & C: $4 \mathrm{~m}^{2} / \mathrm{ST}: 200$ I / HWD: $150 \mathrm{l} / \mathrm{d} / \mathrm{PS}$ & Tokyo & 96 \\
\hline Jordan & C: $4 \mathrm{~m}^{2} / \mathrm{ST}: 200 \mathrm{l} / \mathrm{HWD}: 150 \mathrm{l} / \mathrm{d} / \mathrm{TS}$ & Amman & 98 \\
\hline Latvia & C: $4 \mathrm{~m}^{2} / \mathrm{ST}: 200$ I / HWD: $150 \mathrm{l} / \mathrm{d} / \mathrm{PS}$ & Riga & 100 \\
\hline Lithuania & C: $4 \mathrm{~m}^{2} /$ ST: 200 l / HWD: $150 \mathrm{l} / \mathrm{d} / \mathrm{PS}$ & Vilnius & 100 \\
\hline Luxembourg & C: $4 \mathrm{~m}^{2} / \mathrm{ST}: 200$ I / HWD: $150 \mathrm{l} / \mathrm{d} / \mathrm{PS}$ & Luxembourg & 100 \\
\hline toMacedonia & C: $4 \mathrm{~m}^{2} / \mathrm{ST}: 200 \mathrm{l} / \mathrm{HWD}: 150 \mathrm{l} / \mathrm{d} / \mathrm{PS}$ & Skopje & 100 \\
\hline Malta & C: $4 \mathrm{~m}^{2} / \mathrm{ST}: 200$ I / HWD: $150 \mathrm{l} / \mathrm{d} / \mathrm{PS}$ & Valletta & 100 \\
\hline Mexico & C: $4 \mathrm{~m}^{2} /$ ST: 200 l / HWD: $150 \mathrm{l} / \mathrm{d} / \mathrm{PS}$ & Mexico City & 28 \\
\hline Namibia & C: $4 \mathrm{~m}^{2} / \mathrm{ST}: 200 \mathrm{l} / \mathrm{HWD}: 150 \mathrm{l} / \mathrm{d} / \mathrm{TS}$ & Windhoek & 100 \\
\hline Netherlands & C: $3 \mathrm{~m}^{2} / \mathrm{ST}: 100 \mathrm{l} / \mathrm{HWD}: 110 \mathrm{l} / \mathrm{d} / \mathrm{PDS}$ & De Bilt & 80 \\
\hline New Zealand & C: $4 \mathrm{~m}^{2} / \mathrm{ST}: 300 \mathrm{l} / \mathrm{HWD}: 150 \mathrm{l} / \mathrm{d} / \mathrm{TS}$ & Wellington & 95 \\
\hline Norway & C: $6 \mathrm{~m}^{2} /$ ST: 300 l / HWD: $150 \mathrm{l} / \mathrm{d} / \mathrm{PS}$ & Oslo & 98 \\
\hline Poland & C: $6 \mathrm{~m}^{2} / \mathrm{ST}: 300$ I / HWD: $150 \mathrm{l} / \mathrm{d} / \mathrm{PS}$ & Warsaw & 99 \\
\hline Portuqal & C: $4 \mathrm{~m}^{2} / \mathrm{ST}: 200 \mathrm{l} / \mathrm{HWD}: 150 \mathrm{l} / \mathrm{d} / \mathrm{TS}$ & Lisbon & 95 \\
\hline Romania & C: $4 \mathrm{~m}^{2} / \mathrm{ST}: 200$ I / HWD: $150 \mathrm{l} / \mathrm{d} / \mathrm{PS}$ & Bucharest & 100 \\
\hline Slovak Republic & C: $6 \mathrm{~m}^{2} / \mathrm{ST}: 300$ / / HWD: $150 \mathrm{l} / \mathrm{d} / \mathrm{PS}$ & Bratislava & 100 \\
\hline Slovenia & C: $6 \mathrm{~m}^{2} / \mathrm{ST}: 300$ I / HWD: $150 \mathrm{l} / \mathrm{d} / \mathrm{PS}$ & Ljubliana & 98 \\
\hline South Africa & C: $4 \mathrm{~m}^{2} / \mathrm{ST}: 200 \mathrm{l} / \mathrm{HWD}: 150 \mathrm{l} / \mathrm{d} / \mathrm{TS}$ & Johannesburg & 100 \\
\hline Spain & C: $4 \mathrm{~m}^{2} / \mathrm{ST}: 200$ l/ HWD: $150 \mathrm{l} / \mathrm{d} / \mathrm{TS}$ & Madrid & 95 \\
\hline Sweden & C: $6 \mathrm{~m}^{2} / \mathrm{ST}: 300$ / / HWD: $150 \mathrm{l} / \mathrm{d} / \mathrm{PS}$ & Gothenburg & 10 \\
\hline Switzerland & C: $6 \mathrm{~m}^{2} / \mathrm{ST}: 300$ I / HWD: $150 \mathrm{l} / \mathrm{d} / \mathrm{PS}$ & Zurich & 67 \\
\hline Taiwan & C: $4 \mathrm{~m}^{2} / \mathrm{ST}: 200 \mathrm{l} / \mathrm{HWD}: 150 \mathrm{l} / \mathrm{d} / \mathrm{TS}$ & Taipei & 100 \\
\hline Thailand & C: $4 \mathrm{~m}^{2} / \mathrm{ST}: 200$ I / HWD: $150 \mathrm{l} / \mathrm{d} / \mathrm{TS}$ & Bangkok & 100 \\
\hline Tunisia & C: $4 \mathrm{~m}^{2} / \mathrm{ST}: 200$ I / HWD: $150 \mathrm{l} / \mathrm{d} / \mathrm{TS}$ & Tunis & 100 \\
\hline Turkey & C: $4 \mathrm{~m}^{2} / \mathrm{ST}: 200$ I / HWD: $150 \mathrm{l} / \mathrm{d} / \mathrm{PS}$ & Ankara & 90 \\
\hline United Kinqdom & C: $4 \mathrm{~m}^{2} / \mathrm{ST}: 200 \mathrm{l} / \mathrm{HWD}: 150 \mathrm{l} / \mathrm{d} / \mathrm{PS}$ & London & 100 \\
\hline United States & C: $6 \mathrm{~m}^{2} / \mathrm{ST}: 300 \mathrm{I} / \mathrm{HWD}: 150 \mathrm{l} / \mathrm{d} / \mathrm{PS}$ & Denver, Los Angeles & 100 \\
\hline
\end{tabular}

C: collector area; ST: hot water storage; HWD: hot water demand / day with $60^{\circ} \mathrm{C}$; TS: thermo siphon system; PS: pumped system; PDS: pumped, drain back system

Table 7: Reference systems for domestic hot water systems for single family houses and the percentage of the total collector area in operation (flat-plate and evacuated tube collectors)

Figure 34: Hydraulic scheme of the DHW reference system

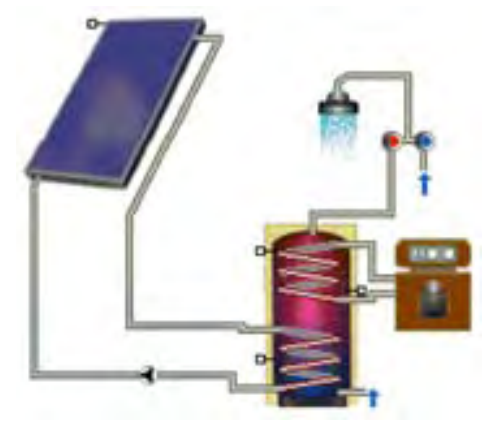




\subsubsection{Solar domestic hot water systems for multi-family houses, hotels and district heating}

The market share in the following table refers to the total capacity in operation of flat-plate and evacuated tube collectors at the end of 2007 for each country.

It must be pointed out, that the market share of the new installed capacity in the year 2007 can differ a lot from the total market share.

\begin{tabular}{|c|c|c|c|}
\hline Country & $\begin{array}{l}\text { reference system } \\
\end{array}$ & reference climate & $\%$ of total market \\
\hline Australia & C: $50 \mathrm{~m}^{2} / \mathrm{ST}: 2500$ I / HWD: $2000 \mathrm{l} / \mathrm{d} / \mathrm{PS}$ & Sydney & 2 \\
\hline Austria & C: $50 \mathrm{~m}^{2}$ / ST: 2500 I / HWD: $2000 \mathrm{l} / \mathrm{d} / \mathrm{PS}$ & Graz & 9 \\
\hline Canada & C: $50 \mathrm{~m}^{2} / \mathrm{ST}: 2500$ I / HWD: $2000 \mathrm{l} / \mathrm{d} / \mathrm{PS}$ & Montreal & 5 \\
\hline China & C: $50 \mathrm{~m}^{2} / \mathrm{ST}: 2500$ I / HWD: $2000 \mathrm{l} / \mathrm{d} / \mathrm{PS}$ & Shanghai & 3 \\
\hline Cyprus & C: $50 \mathrm{~m}^{2}$ / ST: 2500 I / HWD: 2000 l/d / PS & Cyprus & 2 \\
\hline Czech Republic & C: $50 \mathrm{~m}^{2} / \mathrm{ST}: 2500$ I / HWD: $2000 \mathrm{l} / \mathrm{d} / \mathrm{PS}$ & Prague & 1 \\
\hline Denmark & C: $50 \mathrm{~m}^{2}$ / ST: 2500 I / HWD: $2000 \mathrm{l} / \mathrm{d} / \mathrm{PS}$ & Copenhagen & 13 \\
\hline Finland & C: $50 \mathrm{~m}^{2} / \mathrm{ST}: 2500$ I / HWD: $2000 \mathrm{l} / \mathrm{d} / \mathrm{PS}$ & Helsinki & 5 \\
\hline France & C: $50 \mathrm{~m}^{2} / \mathrm{ST}: 2500$ I / HWD: $2000 \mathrm{l} / \mathrm{d} / \mathrm{PS}$ & Paris & 1 \\
\hline Germany & C: $50 \mathrm{~m}^{2} / \mathrm{ST}: 2500 \mathrm{I} / \mathrm{HWD}: 2000 \mathrm{l} / \mathrm{d} / \mathrm{PS}$ & Würzburg & 8 \\
\hline Greece & C: $50 \mathrm{~m}^{2} / \mathrm{ST}: 2500$ I / HWD: $2000 \mathrm{l} / \mathrm{d} / \mathrm{PS}$ & Athens & 2 \\
\hline Hungary & C: $50 \mathrm{~m}^{2} / \mathrm{ST}: 2500$ I / HWD: $2000 \mathrm{l} / \mathrm{d} / \mathrm{PS}$ & Budapest & 1 \\
\hline Israel & C: $50 \mathrm{~m}^{2}$ / ST: 2500 I / HWD: $2000 \mathrm{l} / \mathrm{d} / \mathrm{PS}$ & Jerusalem & 2 \\
\hline Japan & C: $50 \mathrm{~m}^{2} / \mathrm{ST}: 2500 \mathrm{I} / \mathrm{HWD}: 2000 \mathrm{l} / \mathrm{d} / \mathrm{PS}$ & Tokyo & 2 \\
\hline Jordan & C: $50 \mathrm{~m}^{2} / \mathrm{ST}: 2500$ I / HWD: $2000 \mathrm{l} / \mathrm{d} / \mathrm{PS}$ & Amman & 2 \\
\hline Mexico* & C: $50 \mathrm{~m}^{2}$ / ST: 2500 I / HWD: 2000 l/d / PS & Mexico City & 72 \\
\hline Netherlands & C: $50 \mathrm{~m}^{2} / \mathrm{ST}: 2500$ I / HWD: 2000 l/d / PDS & De Bilt & 15 \\
\hline New Zealand & C: $50 \mathrm{~m}^{2}$ / ST: 2500 I / HWD: 2000 l/d / PS & Wellington & 5 \\
\hline Norway & C: $50 \mathrm{~m}^{2} / \mathrm{ST}: 2500$ I / HWD: $2000 \mathrm{l} / \mathrm{d} / \mathrm{PS}$ & Oslo & 1 \\
\hline Poland & C: $50 \mathrm{~m}^{2}$ / ST: 2500 I / HWD: 2000 l/d / PS & Warsaw & 1 \\
\hline Portugal & C: $50 \mathrm{~m}^{2} / \mathrm{ST}: 2500$ I / HWD: $2000 \mathrm{l} / \mathrm{d} / \mathrm{PS}$ & Lisbon & 5 \\
\hline Slovenia & C: $50 \mathrm{~m}^{2}$ / ST: 2500 I / HWD: 2000 l/d / PS & Ljubljana & 2 \\
\hline Spain & C: $50 \mathrm{~m}^{2} / \mathrm{ST}: 2500$ I / HWD: $2000 \mathrm{l} / \mathrm{d} / \mathrm{PS}$ & Madrid & 5 \\
\hline Sweden & C: $1000 \mathrm{~m}^{2} / \mathrm{ST}: 50000$ I / HWD: 40000 l/d / PS & Gothenburg & 25 \\
\hline Switzerland & C: $50 \mathrm{~m}^{2}$ / ST: 2500 I / HWD: $2000 \mathrm{l} / \mathrm{d} / \mathrm{PS}$ & Zurich & 8 \\
\hline Turkey & C: $50 \mathrm{~m}^{2}$ / ST: 2500 I / HWD: 2000 l/d / PS & Ankara & 10 \\
\hline
\end{tabular}

* Industry

C: collector area; ST: hot water storage; HWD: hot water demand / day with $60^{\circ} \mathrm{C}$; TS: thermo siphon system; PS: pumped system; PDS: pumped, drain back system

Table 8: Reference systems for domestic hot water systems for multi-family houses, hotels and district heating and the percentage of the total collector area in operation ( flat-plate and evacuated tube collectors)

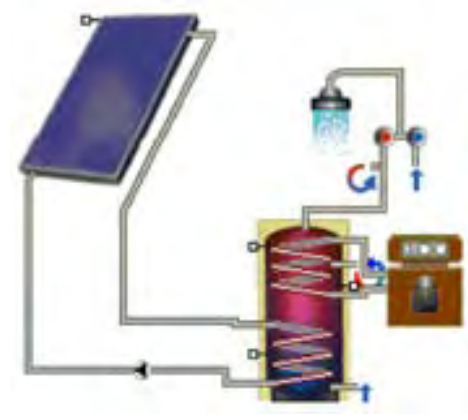

Figure 35: Hydraulic scheme of the DHW system for multi family houses 


\subsubsection{Solar combisystems for domestic hot water and space heating for single family houses}

The market share in the following table is referring to the total capacity in operation of flat-plate and evacuated tube collectors at the end of 2007 for each country.

It must be pointed out that the market share of the new installed capacity in the year 2007 can differ significantly from the total market share.

The reference system is designed for a single-family house with $140 \mathrm{~m}^{2}$ gross area.

\begin{tabular}{|c|c|c|c|}
\hline Country & reference system & reference climate & $\%$ of total market \\
\hline Austria & C: $20 \mathrm{~m}^{2} / \mathrm{ST}: 2000 \mathrm{l} / \mathrm{HWD}: 160 \mathrm{l} / \mathrm{d} / \mathrm{SHD}: 80 \mathrm{kWh} / \mathrm{m}^{2} / \mathrm{PS}$ & Graz & 28 \\
\hline Denmark & C: $15 \mathrm{~m}^{2}$ / ST: $800 \mathrm{l} / \mathrm{HWD}: 160 \mathrm{l} / \mathrm{d} / \mathrm{SHD}: 80 \mathrm{kWh} / \mathrm{m}^{2} / \mathrm{PS}$ & Copenhagen & 1 \\
\hline France & C: $15 \mathrm{~m}^{2} / \mathrm{ST}: 250 \mathrm{l} / \mathrm{HWD}: 160 \mathrm{l} / \mathrm{d} / \mathrm{SHD}: 80 \mathrm{kWh} / \mathrm{m}^{2} / \mathrm{PS}$ & Paris & 4 \\
\hline Germany & C: $12 \mathrm{~m}^{2}$ / ST: $750 \mathrm{l} / \mathrm{HWD}: 160 \mathrm{l} / \mathrm{d} / \mathrm{SHD}: 80 \mathrm{kWh} / \mathrm{m}^{2}$ / PS & Würzburg & 12 \\
\hline Japan & C: $12 \mathrm{~m}^{2} / \mathrm{ST}: 750 \mathrm{l} / \mathrm{HWD}: 160 \mathrm{l} / \mathrm{d} / \mathrm{SHD}: 80 \mathrm{kWh} / \mathrm{m}^{2} / \mathrm{PS}$ & Tokyo & 2 \\
\hline Netherlands & C: $4 \mathrm{~m}^{2} /$ ST $240 \mathrm{l} / \mathrm{HWD}: 160 \mathrm{l} / \mathrm{d} / \mathrm{SHD}: 80 \mathrm{kWh} / \mathrm{m}^{2} /$ PDS & De Bilt & 5 \\
\hline Norway & C: $10 \mathrm{~m}^{2} /$ ST: $1500 \mathrm{l} / \mathrm{HWD}: 160 \mathrm{l} / \mathrm{d} / \mathrm{SHD}: 100 \mathrm{kWh} / \mathrm{m}^{2} / \mathrm{PS}$ & Oslo & 1 \\
\hline Sweden & C: $12 \mathrm{~m}^{2}$ / ST: $1000 \mathrm{l} / \mathrm{HWD}: 160 \mathrm{l} / \mathrm{d} / \mathrm{SHD}: 100 \mathrm{kWh} / \mathrm{m}^{2}$ / PS & Gothenburg & 65 \\
\hline Switzerland & C: $15 \mathrm{~m}^{2}$ / ST: $1000 \mathrm{l} / \mathrm{HWD}: 160 \mathrm{l} / \mathrm{d} / \mathrm{SHD}: 80 \mathrm{kWh} / \mathrm{m}^{2} / \mathrm{PS}$ & Zurich & 25 \\
\hline
\end{tabular}

C: collector area; ST: hot water storage; TS: thermo siphon system; PS: pumped system; PDS: pumped, drain back system; HWD: hot water demand per day with $60^{\circ} \mathrm{C}$; SHD: space heat demand $\left[\mathrm{kWh} / \mathrm{m}^{2}\right.$ a]

Table 9: Reference systems for combisystems for single-family houses and the percentage of the total collector area in operation (flat-plate and evacuated tube collectors)

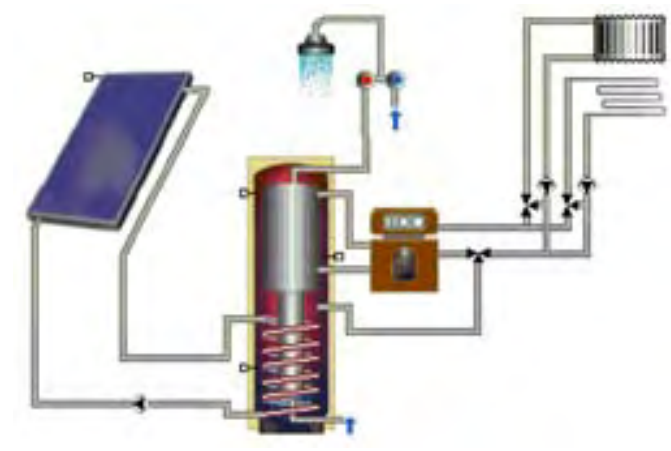

Figure 36: Hydraulic scheme of the solar combi reference system 


\subsection{Reference collector}

7.2.1 Data of the reference absorber for swimming pool heating
$\eta=0.85$
$a_{1}=20\left[\mathrm{~W} / \mathrm{m}^{2} \mathrm{~K}\right]$
$\mathrm{a}_{2}=0.1\left[\mathrm{~W} / \mathrm{m}^{2} \mathrm{~K}^{2}\right]$

7.2.2 Data of the reference collector for all other applications

$\eta=0.8$

$\mathrm{al}=3.69\left[\mathrm{~W} / \mathrm{m}^{2} \mathrm{~K}\right]$

$\mathrm{a}_{2}=0.007\left[\mathrm{~W} / \mathrm{m}^{2} \mathrm{~K}^{2}\right]$

\subsection{Population data}

\begin{tabular}{|l|r|}
\hline Country & Inhabitants \\
\hline Albania & 3.190 .000 \\
\hline Australia & 20.743 .000 \\
\hline Austria & 8.315 .000 \\
\hline Barbados & 294.000 \\
\hline Belgium & 10.457 .000 \\
\hline Brazil & 191.791 .000 \\
\hline Bulgaria & 7.639 .000 \\
\hline Canada & 32.876 .000 \\
\hline China & 1.328 .630 .000 \\
\hline Cyprus & 855.000 \\
\hline Czech Republic & 10.186 .000 \\
\hline Denmark & 5.442 .000 \\
\hline Estonia & 1.335 .000 \\
\hline Finland & 5.277 .000 \\
\hline France* & 63.561 .000 \\
\hline Germany & 82.599 .000 \\
\hline Greece & 11.147 .000 \\
\hline
\end{tabular}

\begin{tabular}{|l|r|}
\hline Country & Inhabitants \\
\hline Hungary & 10.030 .000 \\
\hline India & 1.169 .016 .000 \\
\hline Ireland & 4.301 .000 \\
\hline Israel & 6.928 .000 \\
\hline Italy & 58.877 .000 \\
\hline Japan & 127.967 .000 \\
\hline Jordan & 5.924 .000 \\
\hline Latvia & 2.277 .000 \\
\hline Lithuania & 3.431 .000 \\
\hline Luxembourg & 465.000 \\
\hline Macedonia & 2.034 .000 \\
\hline Malta & 402.000 \\
\hline Mexico & 107.029 .000 \\
\hline Namibia & 2.031 .000 \\
\hline Netherlands & 16.299 .000 \\
\hline New Zealand & 4.028 .000 \\
\hline Norway & 4.620 .000 \\
\hline
\end{tabular}

\begin{tabular}{|l|r|}
\hline Country & Inhabitants \\
\hline Poland & 38.530 .000 \\
\hline Portugal & 10.495 .000 \\
\hline Romania & 21.711 .000 \\
\hline Slovak Republic & 5.401 .000 \\
\hline Slovenia & 1.967 .000 \\
\hline South Africa & 47.432 .000 \\
\hline Spain & 43.064 .000 \\
\hline Sweden & 9.041 .000 \\
\hline Switzerland & 7.252 .000 \\
\hline Taiwan & 24.000 .000 \\
\hline Thailand & 24.000 .000 \\
\hline Tunisia & 10.102 .000 \\
\hline Turkey & 73.193 .000 \\
\hline United Kingdom & 59.668 .000 \\
\hline United States & 298.213 .000 \\
\hline TOTAL & $\mathbf{4 . 0 3 5 . 1 4 1 . 0 0 0}$ \\
\hline
\end{tabular}

Table 10: Inhabitants of the 48 surveyed countries in alphabetic order Data source: Statistisches J ahrbuch Österreich, 2008, http://www. statistik.at

\begin{tabular}{|l|r|}
\hline *France & $\mathbf{6 3 . 5 6 1 . 0 0 0}$ \\
\hline Guadeloupe & 445.000 \\
\hline Martinique & 399.000 \\
\hline Réunion & 807.000 \\
\hline Polynesia & 263.000 \\
\hline France métropole & 61.647 .000 \\
\hline
\end{tabular}

Table 11:

Inhabitants of France including

Overseas Departments

\begin{tabular}{|l|r|}
\hline Economic Region & Inhabitants \\
\hline United States + Canada & 338.702 .000 \\
\hline Japan & 127.967 .000 \\
\hline China + Taiwan & 1.351 .230 .000 \\
\hline Europe & 512.093 .000 \\
\hline Australia + New Zealand & 24.922 .000 \\
\hline Others & 1.680 .227 .000 \\
\hline TOTAL & $\mathbf{4 . 0 3 5 . 1 4 1 . 0 0 0}$ \\
\hline
\end{tabular}

Europe: EU-27, Albania, Macedonia, Norway, Overseas Departments of France, Switzerland. Others: Barbados, Brazil, India, Israel, Jordan, Mexico, Namibia, South Africa, Thailand, Tunisia and Turkey

Table 12: Inhabitants per Economic Region

Population data source: Statistisches J ahrbuch Österreich, 2008, http://www.statistik.at 


\subsection{Installed capacity in 2006}

\begin{tabular}{|c|c|c|c|c|c|c|}
\hline \multirow{2}{*}{ Country } & \multicolumn{3}{|c|}{ Water Collectors } & \multicolumn{2}{|c|}{ Air Collectors } & \multirow{2}{*}{ TOTAL $\left[\mathrm{MW}_{\mathrm{th}}\right]$} \\
\hline & unglazed $* * *$ & glazed & evacuated tube & unglazed*** & glazed*** & \\
\hline Albania & & 5.57 & 0.05 & & & 5.63 \\
\hline Australia & 385.00 & 109.20 & 10.50 & & & 504.70 \\
\hline Austria & 4.85 & 202.82 & 2.05 & & & 209.72 \\
\hline Barbados & & 1.91 & & & & 1.91 \\
\hline Belgium & 6.18 & 21.89 & 3.06 & & & 31.12 \\
\hline Brazil & & 304.03 & & & & 304.03 \\
\hline Bulgaria & & 1.54 & & & & 1.54 \\
\hline Canada & 25.40 & 0.92 & 0.50 & 16.41 & 0.03 & 43.26 \\
\hline China & & $1,260.00$ & $11,340.00$ & & & $12,600.00$ \\
\hline Cyprus & & 42.00 & & & & 42.00 \\
\hline Czech Republic & 4.20 & 12.94 & 2.48 & & & 19.62 \\
\hline Denmark & 1.12 & 19.95 & 0.70 & & 4.90 & 26.67 \\
\hline Estonia & & 0.21 & & & & 0.21 \\
\hline Finland & & 2.38 & & & & 2.38 \\
\hline France * & 4.20 & 198.80 & 7.70 & & & 210.70 \\
\hline Germany & 21.00 & 945.00 & 105.00 & & & $1,071.00$ \\
\hline Greece & & 174.30 & & & & 174.30 \\
\hline Hungary & & 0.70 & & & & 0.70 \\
\hline India & & 350.00 & & & 3.50 & 353.50 \\
\hline I reland & & 2.87 & 0.63 & & & 3.50 \\
\hline Israel & 2.66 & 155.40 & & & & 158.06 \\
\hline Italy & 2.56 & 109.06 & 18.59 & & & 130.20 \\
\hline Japan & & 183.87 & 0.97 & 12.21 & & 197.04 \\
\hline Jordan & & 5.37 & 2.52 & & & 7.89 \\
\hline Lativa & & 0.84 & & & & 0.84 \\
\hline Lithuania & & 0.42 & & & & 0.42 \\
\hline Luxembourg & & 1.75 & & & & 1.75 \\
\hline Macedonia & & 1.48 & 0.03 & & & 1.51 \\
\hline Malta & & 3.15 & & & & 3.15 \\
\hline Mexico & 20.32 & 47.41 & & & & 67.73 \\
\hline Namibia & & 1.20 & & & & 1.20 \\
\hline Netherlands & 17.09 & 10.46 & & & & 27.55 \\
\hline New Zealand & 0.42 & 6.72 & 2.35 & & & 9.49 \\
\hline Norway & & 0.49 & 0.07 & & & 0.56 \\
\hline Poland & 0.11 & 24.61 & 4.38 & & & 29.09 \\
\hline Portugal & & 19.81 & & & & 19.81 \\
\hline Romania & & 0.28 & & & & 0.28 \\
\hline Slovak Republic & & 5.39 & 0.56 & & & 5.95 \\
\hline Slovenia & & 4.41 & 0.42 & & & 4.83 \\
\hline South Africa & 45.57 & 9.66 & & & & 55.23 \\
\hline Spain & & 113.31 & 9.19 & & & 122.50 \\
\hline Sweden & 9.39 & 13.88 & 6.10 & & & 29.37 \\
\hline Switzerland ** & 6.27 & 35.25 & 1.06 & 0.70 & & 43.27 \\
\hline Taiwan & & 79.55 & 5.99 & & & 85.54 \\
\hline Thailand & & 4.76 & & & & 4.76 \\
\hline Tunisia & & 24.17 & 0.33 & & & 24.50 \\
\hline Turkey & & 490.00 & & & & 490.00 \\
\hline United Kingdom & & 9.80 & 9.80 & & & 19.60 \\
\hline United States & 951.85 & 78.68 & 3.37 & & 0.37 & $1,034.26$ \\
\hline TOTAL & $1,508.19$ & $5,098.20$ & $11,538.36$ & 29.31 & 8.79 & $18,182.86$ \\
\hline
\end{tabular}

* France: includes Overseas Departments

** Unglazed air collectors in Switzerland: this is a very simple site-built system for hay drying purposes

*** If no data is given: no reliable data base for this collector type available

Table 13: Installed capacity in 2006, $\mathrm{MW}_{\mathrm{th}} / \mathrm{a}$ 


\subsection{6 and 2007 data in square meters collector area}

The data presented in Chapters 3 to 5 were originally collected in square meters. Through an agreement of international experts the collector areas of these solar thermal applications have been converted and are shown in installed capacity.

Making the installed capacity of solar thermal collectors comparable with that of other energy sources, solar thermal experts from seven countries agreed upon a methodology to convert installed collector area into solar thermal capacity. The methodology was developed during a meeting with IEA SHC Programme and major solar thermal trade associations in Gleisdorf, Austria in September 2004. The represented associations from Austria, Canada, Germany, the Netherlands, Sweden and the USA as well as the European Solar Thermal Industry Federation (ESTIF) and the IEA SHC Programme agreed to use a factor of $0.7 \mathrm{~kW}_{\text {th }} / \mathrm{m}^{2}$ to derive the nominal capacity from the area of installed collectors.

Nevertheless, solar thermal collectors are traditionally quoted in square meters and therefore Tables 15-17 provide the 2006 and 2007 data in $\mathrm{m}^{2}$.

\begin{tabular}{|c|c|c|c|c|c|c|}
\hline \multirow{2}{*}{ Country } & \multicolumn{3}{|c|}{ Water Collectors } & \multicolumn{2}{|c|}{ Air Collectors } & \multirow{2}{*}{ TOTAL $\left[\mathbf{m}^{2}\right]$} \\
\hline & unglazed $* * *$ & glazed & evacuated tube & unglazed*** & glazed*** & \\
\hline Albania & & 7,960 & 76 & & & 8,036 \\
\hline Australia & 550,000 & 156,000 & 15,000 & & & 721,000 \\
\hline Austria & 6,935 & 289,745 & 2,924 & & & 299,604 \\
\hline Barbados & & 2,731 & & & & 2,731 \\
\hline Belgium & 8,828 & 31,267 & 4,369 & & & 44,464 \\
\hline Brazil & & 434,331 & & & & 434,331 \\
\hline Bulgaria & & 2,200 & & & & 2,200 \\
\hline Canada & 36,292 & 1,312 & 712 & 23,441 & 38 & 61,795 \\
\hline China & & $1,800,000$ & $16,200,000$ & & & $18,000,000$ \\
\hline Cyprus & & 60,000 & & & & 60,000 \\
\hline Czech Republic & 6,000 & 18,490 & 3,540 & & & 28,030 \\
\hline Denmark & 1,600 & 28,500 & 1,000 & & 7,000 & 38,100 \\
\hline Estonia & & 300 & & & & 300 \\
\hline Finland & & 3,400 & & & & $\mathbf{3 , 4 0 0}$ \\
\hline France * & 6,000 & 284,000 & 11,000 & & & 301,000 \\
\hline Germany & 30,000 & $1,350,000$ & 150,000 & & & $1,530,000$ \\
\hline Greece & & 249,000 & & & & 249,000 \\
\hline Hungary & & 1,000 & & & & 1,000 \\
\hline India & & 500,000 & & & 5,000 & 505,000 \\
\hline I reland & & 4,100 & 900 & & & 5,000 \\
\hline Israel & 3,800 & 222,000 & & & & 225,800 \\
\hline Italy & 3,650 & 155,798 & 26,552 & & & 186,000 \\
\hline Japan & & 262,665 & 1,382 & 17,436 & & 281,483 \\
\hline Jordan & & 7,666 & 3,600 & & & 11,266 \\
\hline Lativa & & 1,200 & & & & 1,200 \\
\hline Lithuania & & 600 & & & & 600 \\
\hline Luxembourg & & 2,500 & & & & 2,500 \\
\hline Macedonia & & 2,118 & 36 & & & 2,154 \\
\hline Malta & & 4,500 & & & & 4,500 \\
\hline Mexico & 29,029 & 67,735 & & & & 96,764 \\
\hline Namibia & & 1,720 & & & & 1,720 \\
\hline Netherlands & 24,419 & 14,937 & & & & 39,356 \\
\hline New Zealand & 600 & 9,600 & 3,350 & & & 13,550 \\
\hline Norway & & 700 & 100 & & & 800 \\
\hline Poland & 150 & 35,150 & 6,250 & & & 41,550 \\
\hline Portugal & & 28,300 & & & & 28,300 \\
\hline Romania & & 400 & & & & 400 \\
\hline Slovak Republic & & 7,700 & 800 & & & 8,500 \\
\hline Slovenia & & 6,300 & 600 & & & 6,900 \\
\hline South Africa & 65,100 & 13,800 & & & & 78,900 \\
\hline Spain & & 161,875 & 13,125 & & & 175,000 \\
\hline Sweden & 13,416 & 19,825 & 8,713 & & & 41,954 \\
\hline Switzerland ** & 8,953 & 50,355 & 1,508 & 1,000 & & 61,816 \\
\hline Taiwan & & 113,646 & 8,554 & & & 122,200 \\
\hline Thailand & & 6,800 & & & & 6,800 \\
\hline Tunisia & & 34,526 & 474 & & & 35,000 \\
\hline Turkey & & 700,000 & & & & 700,000 \\
\hline United Kingdom & & 14,000 & 14,000 & & & 28,000 \\
\hline United States & $1,359,781$ & 112,396 & 4,811 & & 524 & $1,477,513$ \\
\hline TOTAL & $2,154,553$ & $7,283,148$ & $16,483,376$ & 41,877 & 12,562 & $25,975,517$ \\
\hline
\end{tabular}

* France: includes Overseas Departments

** Unglazed air collectors in Switzerland: this is a very simple site-built system for hay drying purposes

$* * *$ If no data is given: no reliable data base for this collector type available

Table 14: Collector Area installed in 2006, $\mathrm{m}^{2} / \mathrm{a}$ 


\begin{tabular}{|c|c|c|c|c|c|c|}
\hline \multirow{2}{*}{ Country } & \multicolumn{3}{|c|}{ Water Collectors } & \multicolumn{2}{|c|}{ Air Collectors } & \multirow{2}{*}{ TOTAL $\left[\mathrm{m}^{2}\right]$} \\
\hline & unglazed $* * *$ & glazed & evacuated tube & unglazed $* * *$ & glazed*** & \\
\hline Albania & & 9,290 & 88 & & & 9,378 \\
\hline Australia & 576,000 & 203,000 & 3,000 & & & 782,000 \\
\hline Austria & 8,662 & 277,620 & 3,399 & & & 289,681 \\
\hline Barbados & & 2,731 & & & & 2,731 \\
\hline Belgium & 8,828 & 37,000 & 5,000 & & & 50,828 \\
\hline Brazil & 97,442 & 475,394 & 350 & & & 573,186 \\
\hline Bulgaria & & 2,500 & & & & 2,500 \\
\hline Canada & 39,879 & 1,462 & 2,385 & 17,056 & 128 & 60,910 \\
\hline China & & $1,100,000$ & $20,040,000$ & & & $21,140,000$ \\
\hline Cyprus & & 15,000 & 1,000 & & & 16,000 \\
\hline Czech Republic & 6,000 & 18,900 & 6,100 & & & 31,000 \\
\hline Denmark & 600 & 23,000 & 400 & 3,400 & 3,500 & 30,900 \\
\hline Estonia & & 350 & & & & 350 \\
\hline Finland & & 2,100 & 622 & & & 2,722 \\
\hline France * & 5,300 & 305,000 & 12,700 & & & 323,000 \\
\hline Germany & 30,000 & 840,000 & 100,000 & & & 970,000 \\
\hline Greece & & 279,000 & 4,000 & & & 283,000 \\
\hline Hungary & & 6,000 & 2,000 & & & 8,000 \\
\hline India & & 250,000 & & & 7,000 & 257,000 \\
\hline I reland & & 14,872 & 4,799 & & & 19,671 \\
\hline Israel & 700 & 71,000 & & & & 71,700 \\
\hline Italy & 3,650 & 210,000 & 35,000 & & & 248,650 \\
\hline Japan & & 166,223 & 4,051 & & 12,509 & 182,783 \\
\hline Jordan & & 7,666 & 3,600 & & & 11,266 \\
\hline Lativa & & 1,500 & & & & 1,500 \\
\hline Lithuania & & 700 & & & & 700 \\
\hline Luxembourg & & 3,000 & & & & 3,000 \\
\hline Macedonia & & 1,952 & 200 & & & 2,152 \\
\hline Malta & & 5,500 & & & & 5,500 \\
\hline Mexico & 46,281 & 107,989 & & & & 154,270 \\
\hline Namibia & & 2,810 & 190 & & & 3,001 \\
\hline Netherlands & 27,722 & 19,920 & & & & 47,642 \\
\hline New Zealand & 600 & 11,800 & 5,150 & & & 17,550 \\
\hline Norway & 200 & 720 & 50 & & & 970 \\
\hline Poland & & 47,032 & 21,115 & & & 68,147 \\
\hline Portugal & 618 & 44,483 & 5,696 & & & 50,797 \\
\hline Romania & & 500 & & & & 500 \\
\hline Slovak Republic & & 15,554 & 9,911 & & & 25,465 \\
\hline Slovenia & & 6,515 & 1,150 & & & 7,665 \\
\hline South Africa & 67,300 & 14,000 & 0 & & & 81,300 \\
\hline Spain & 3,000 & 251,000 & 11,000 & & & 265,000 \\
\hline Sweden & 20,435 & 15,554 & 9,911 & & & 45,900 \\
\hline Switzerland ** & 10,320 & 63,022 & 2,554 & 2,000 & & 77,896 \\
\hline Taiwan & & 125,000 & 9,900 & & & 134,900 \\
\hline Thailand & & 8,000 & & & & 8,000 \\
\hline Tunisia & & 39,000 & 1,000 & & & 40,000 \\
\hline Turkey & & 700,000 & & & & 700,000 \\
\hline United Kingdom & & 27,000 & 27,000 & & & 54,000 \\
\hline United States & $1,125,038$ & 129,620 & 20,520 & & 1,267 & $1,276,445$ \\
\hline TOTAL & $2,078,575$ & $5,960,280$ & $20,353,841$ & 22,456 & 24,403 & $28,439,555$ \\
\hline
\end{tabular}

* France: includes Overseas Departments

** Unglazed air collectors in Switzerland: this is a very simple site-built system for hay drying purposes

*** If no data is given: no reliable data base for this collector type available

Table 15: Collector Area installed in 2007, $\mathrm{m}^{2}$ / a 


\begin{tabular}{|c|c|c|c|c|c|c|}
\hline \multirow{2}{*}{ Country } & \multicolumn{3}{|c|}{ Water Collectors } & \multicolumn{2}{|c|}{ Air Collectors } & \multirow{2}{*}{ TOTAL $\left[\mathrm{m}^{2}\right]$} \\
\hline & unglazed $* * *$ & glazed & evacuated tube & unglazed*** & glazed*** & \\
\hline Albania & & 49,930 & 246 & & & 50,176 \\
\hline Australia & $4,070,000$ & $1,660,000$ & 23,000 & & & $5,753,000$ \\
\hline Austria & 608,890 & $2,949,558$ & 42,983 & & & $3,601,431$ \\
\hline Barbados & & 82,794 & & & & 82,794 \\
\hline Belgium & 48,828 & 133,750 & 12,368 & & & 194,946 \\
\hline Brazil & 97,442 & $3,587,499$ & 350 & & & $3,685,291$ \\
\hline Bulgaria & & 27,600 & & & & 27,600 \\
\hline Canada & 665,920 & 81,755 & 4,747 & 129,962 & 191 & 882,575 \\
\hline China & & $10,400,000$ & $103,740,000$ & & & $114,140,000$ \\
\hline Cyprus & & 794,749 & 962 & & & 795,710 \\
\hline Czech Republic & 15,230 & 97,090 & 15,490 & & & 127,810 \\
\hline Denmark & 21,370 & 393,860 & 3,400 & 3,400 & 18,750 & 440,780 \\
\hline Estonia & & 1,470 & & & & 1,470 \\
\hline Finland & 500 & 15,583 & 1,302 & & & 17,385 \\
\hline France $*$ & 104,500 & $1,416,500$ & 33,000 & & & $1,554,000$ \\
\hline Germany & 750,000 & $7,784,095$ & 863,982 & & & $9,398,077$ \\
\hline Greece & & $3,566,200$ & 6,800 & & & $3,573,000$ \\
\hline Hungary & 2,800 & 41,340 & 2,560 & & & 46,700 \\
\hline India & & $2,150,000$ & & & 17,000 & $2,167,000$ \\
\hline I reland & & 27,657 & 7,910 & & & 35,567 \\
\hline Israel & 24,200 & $4,936,900$ & & & & $4,961,100$ \\
\hline Italy & 26,270 & 873,520 & 102,860 & & & $1,002,650$ \\
\hline Japan & & $6,824,569$ & 127,069 & 434,371 & 12,509 & $7,398,518$ \\
\hline Jordan & & 840,332 & 7,200 & & & 847,532 \\
\hline Lativa & & 5,350 & & & & 5,350 \\
\hline Lithuania & & 3,450 & & & & 3,450 \\
\hline Luxembourg & & 18,900 & & & & 18,900 \\
\hline Macedonia & & 19,070 & 200 & & & 19,270 \\
\hline Malta & & 29,360 & & & & 29,360 \\
\hline Mexico & 467,592 & 443,880 & & & & 911,473 \\
\hline Namibia & & 5,979 & 190 & & & 6,169 \\
\hline Netherlands & 343,527 & 329,506 & & & & 673,033 \\
\hline New Zealand & 6,217 & 102,914 & 10,046 & & & 119,177 \\
\hline Norway & 1,600 & 11,220 & 150 & & 1,200 & 14,170 \\
\hline Poland & 1,300 & 197,874 & 36,723 & 3,000 & 2,500 & 241,397 \\
\hline Portugal & 594 & 276,038 & 5,477 & & & 282,109 \\
\hline Romania & & 69,600 & & & & 69,600 \\
\hline Slovak Republic & & 88,304 & 9,911 & & & 98,215 \\
\hline Slovenia & & 115,815 & 1,150 & & & 116,965 \\
\hline South Africa & 628,610 & 247,680 & & & & 876,290 \\
\hline Spain & 3,000 & $1,164,164$ & 45,600 & & & $1,212,764$ \\
\hline Sweden & 80,000 & 223,000 & 29,000 & & & 332,000 \\
\hline Switzerland ** & 212,400 & 433,490 & 25,420 & 838,000 & & $1,509,310$ \\
\hline Taiwan & & $1,136,919$ & 118,421 & & & $1,255,340$ \\
\hline Thailand & & 70,000 & & & & 70,000 \\
\hline Tunisia & & 216,523 & 1,477 & & & 218,000 \\
\hline Turkey & & $10,150,000$ & & & & $10,150,000$ \\
\hline United Kingdom & & 277,920 & 27,000 & & & 304,920 \\
\hline United States & $27,639,364$ & $1,898,841$ & 578,376 & 93 & 229,744 & $30,346,417$ \\
\hline TOTAL & $35,820,154$ & $66,272,546$ & $105,885,370$ & $1,408,827$ & 281,894 & $209,668,790$ \\
\hline
\end{tabular}

* France: includes Overseas Departments

** Unglazed air collectors in Switzerland: this is a very simple site-built system for hay drying purposes

$* * *$ If no data is given: no reliable data base for this collector type available

Table 16: Total Collector Area in operation at the end of 2007, $\mathrm{m}^{2}$ 


\subsection{References to persons and institutions that have supplied the data}

The following persons and members of the Executive Committee of the IEA Solar Heating and Cooling Programme supplied the data and the reference systems for their respective countries:

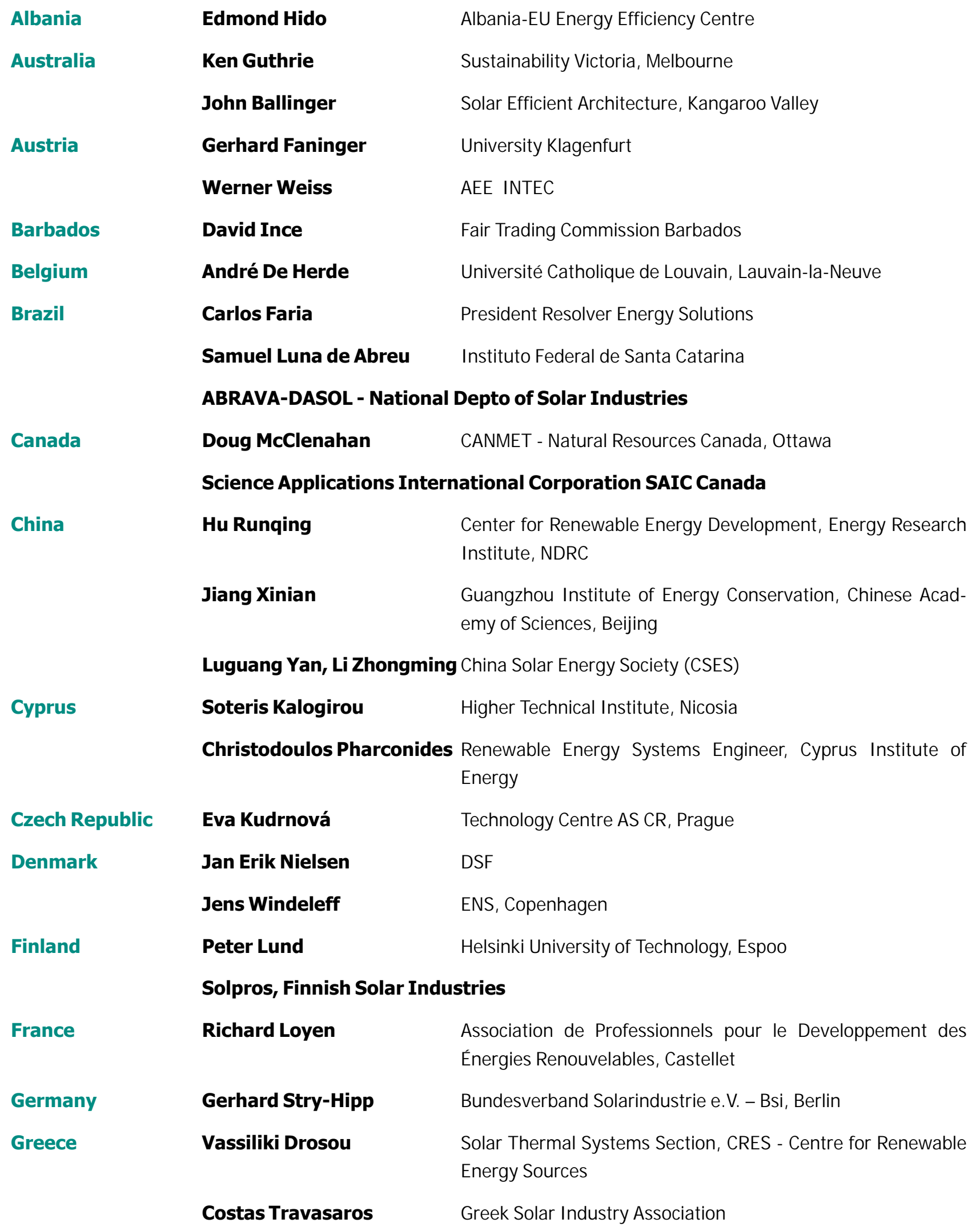




\begin{tabular}{|c|c|c|}
\hline Hungary & Istvan Farkas & Hungarian Solar Energy Society \\
\hline \multirow[t]{2}{*}{ India } & Amit Kumar & Coordinator, Energy Environment Technology Division, TERI \\
\hline & C. Palaniappan & Planters Energy Network - PEN \\
\hline Ireland & Neil Cammish & $\begin{array}{l}\text { Renewable Energy Information Office, Sustainable Energy } \\
\text { Ireland }\end{array}$ \\
\hline \multirow[t]{2}{*}{ Israel } & Asher Vaturi & ICTAF, Tel Aviv University \\
\hline & \multicolumn{2}{|c|}{$\begin{array}{l}\text { Ministry of National Infrastructures, } \\
\text { Solel and Israel Manufacturing Association, Tel Aviv } \\
\text { ICBS Israel Central Bureau of Statistics }\end{array}$} \\
\hline \multirow[t]{2}{*}{ Italy } & Valeria Verga & Associazione Italiana Solare Termico \\
\hline & Michele Zinzi & ENEA TER-ENESIST s.p., Rome \\
\hline \multirow[t]{4}{*}{ Japan } & $\begin{array}{l}\text { Noriaki Yamashita, } \\
\text { Takuo Yamaguchi }\end{array}$ & Institute for Sustainable Energy Policies (ISEP) \\
\hline & \multicolumn{2}{|c|}{ Solar System Development Association(SSDA) } \\
\hline & \multicolumn{2}{|c|}{ OM Solar Association, Japan, www.omsolar.net } \\
\hline & Kazuki Yoshimura & $\begin{array}{l}\text { National Institute of Advanced Industrial Science and Technol- } \\
\text { ogy, Nagoya }\end{array}$ \\
\hline Jordan & Walid Shahin & National Energy Research Center NERC \\
\hline \multirow[t]{2}{*}{ Macedonia } & Dejan Zrmanovski & $\begin{array}{l}\text { Ministry of Economy, Department of Energy, Energy Efficiency } \\
\text { and Renewable Energy Sources Unit }\end{array}$ \\
\hline & Sanja Popovska-Vasilevska & Solar Macedonia - Macedonian Association for solar energy \\
\hline \multirow[t]{3}{*}{ Mexico } & $\begin{array}{l}\text { Wilfrido Rivera } \\
\text { Gomez-Franco }\end{array}$ & $\begin{array}{l}\text { Centro de Investigacion en Energia, Universidad Nacional } \\
\text { Autonoma de Mexico }\end{array}$ \\
\hline & Claudio Estrada & Centro de Investigacion en Energia, Temixco, Morelos \\
\hline & \multicolumn{2}{|c|}{ Asociación Nacional de Energía Solar, A.C. } \\
\hline \multirow[t]{3}{*}{ Namibia } & \multicolumn{2}{|c|}{ Ministry of Mines \& Energy } \\
\hline & Kudakwashe Ndhlukula & Renewable Energy \& Energy Efficiency Institute-REEE \\
\hline & Brita Emmermacher & The Desert Research Foundation of Namibia, Energy Desk \\
\hline \multirow[t]{2}{*}{ Netherlands } & Reinoud Segers & Statistics Netherlands \\
\hline & Lex Bosselaar & SenterNovem, Utrecht \\
\hline New Zealand & Michael Donn & School of Architecture, Victoria University of Wellington \\
\hline & Brian Cox & Solar Industries Association New Zealand \\
\hline Norway & Fritjof Salvesen & KanEnergi AS, Oslo \\
\hline Poland & $\begin{array}{l}\text { Grzegorz Wiśniewski, } \\
\text { Aneta Wiecka }\end{array}$ & EC BREC Institute for Renewable Energy Ltd., Warsaw \\
\hline Portugal & João Farinha Mendes & DER/INETI - Edificio G, Lisbon \\
\hline
\end{tabular}


Slovenia

South Africa

Spain

Sweden

Switzerland

Taiwan

Tunisia

Turkey

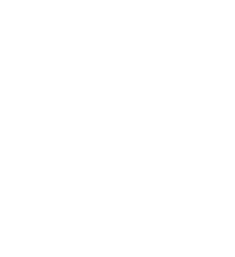

United States

\section{Gradbeni Institut ZRMK, Ljubliana}

Dieter Holm

Sustainable Energy Society of Southern Africa, Pretoria

Nadia Hamid, Mark Tanton Energy Development Corporation (EDC) of the Central Energy Fund (CEF)

Esther Rojas Bravo Renewable Energy Division, CIEMAT, Madrid

\section{Asociación Solar De La Industria Térmica (ASIT)}

Jan-Olof Dalenbäck Chalmers University of Technology, Göteborg

Solar Energy Association of Sweden - SEAS

Urs Wolfer and

Federal Office of Energy, Bern

Andreas Eckmanns

Shyi-min Lu, Tsung-Chi Chen

Sami Marrouki

Energy and Environment Research Laboratories (EEL), Industrial Technology Research I nstitute (ITRI)

MEDREC (Centre Méditerranéen des Energies Renouvelables)

Ghazi Ben Salem

ANME

A. Kutay

Sebahattin Öz

Gulsun Erkul

ÜLKE, Export Department, EZINC Metal San. ve Tic. A.S.

Solar Energy Division, Electrical Power Survey and Development Administration in Turkey

First Secretary (Energy Adviser), Permanent Delegation of Turkey to the OECD

Mehmet Çağlar

Ministery of Energy and Natural Resources of TURKEY

Drury Crawley

U.S. Department of Energy, Washington D.C. 


\subsection{Reports and statistics used in this report}

- European Solar Thermal Industry Federation (ESTIF): Solar Thermal Markets in Europe, Trends and Market Statistics 2006, 2007

- Solar Thermal Barometer, EurObserv'ER, Nr. 187-2008

- Renewables 2007, Global Status Report, 2008, Deutsche Gesellschaft für Technische Zusammenarbeit (GTZ) $\mathrm{GmbH}$

- National Energy Balance 2006, Mexico, 2008

- Dalenbäck, Jan-Olof: Solar District Heating and Cooling, 1st draft report for the European Solar Thermal Technology Platform, 2007

- Biermayr, P. et. al: Erneuerbare Energie in Österreich, Marktentwicklung 2007, BMVIT, Wien, 2008

- SOFAS: Markterhebung Sonnenenergie 2007, Teilstatistik der Schweizerischen Statistik der erneuerbaren Energien, Bundesamt für Energie, Bern, 2008

- BCSE clean energy report, Australia, 2007

- Solar Thermal Collector Manufacturing Activities 2007, Energy I nformation Administration, US DOE, Washington, October 2008

- Energy Policy Statistical Support Unit, Sustainable Energy I reland, SEI-REIO survey 2007, I reland

- South Africa Yearbook 2006-2007, Minerals, energy and geology, www.dme.gov.za/energy/renew_solar.stm

- SARASIN, Sustainability Report, Solar Energy 2007, Bank Sarasin \& Co. Ltd (“BSC”), Switzerland, 2008

- Annual report - Ministry for New and Renewable Energy, Government of India, http://mnes.nic. in/

- CBS: Statistics Netherlands, Rijswijk, www.cbs.nl 


\subsection{Index of figures}

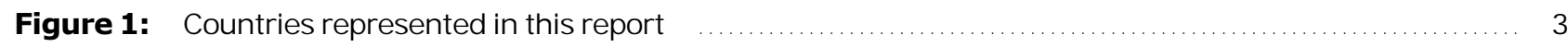

Figure 2: Total capacity in operation $\left[\mathrm{GW}_{\mathrm{el}}\right],\left[\mathrm{GW}_{\mathrm{th}}\right] 2007$ and annually energy generated $\ldots \ldots \ldots \ldots \ldots \ldots \ldots$

Figure 3: Distribution of the worldwide capacity in operation 2007 by collector type f..................... 9

Figure 4: Total capacity in operation of water collectors of the 10 leading countries at the end of $2007 \quad \ldots \ldots .9$

Figure 5: Total capacity of glazed flat-plate and evacuated tube collectors in operation at the end of $2007 \quad$. 10

Figure 6: Total capacity of glazed flat-plate and evacuated tube collectors in operation at the end of 2007 in $\mathrm{kW}_{\text {th }}$ per 1,000 inhabitants

Figure 7: Total capacity of glazed flat-plate and evacuated tube collectors in operation by economic region at the end of 2007

Figure 8: Total capacity of glazed flat-plate and evacuated tube collectors in operation by economic region at the end of 2007 in $\mathrm{kW}_{\text {th }}$ per 1,000 inhabitants

Figure 9: Total capacity of unglazed water collectors in operation at the end of 2007

Figure 10: Total capacity of unglazed water collectors in operation at end of $2007 \mathrm{in} \mathrm{kW}_{\text {th }}$ per 1,000 inhabitants

Figure 11: Total capacity of unglazed collectors in operation by economic region at the end of 2007

Figure 12: Total capacity of unglazed collectors in operation by economic region at the end of 2007 in $\mathrm{kW}_{\text {th }}$ per 1,000 inhabitants

Figure 13: Annual installed capacity of flat-plate and evacuated tube collectors from 1999 to 2007

Figure 14: Annual installed capacity of flat-plate and evacuated tube collectors in $\mathrm{kW}_{\text {th }}$ per 1,000 inhabitants from 1999 to 2007

Figure 15: Annual installed capacity of unglazed water collectors from 1999 to 2007

Figure 16: Annual collector yield of glazed flat-plate and evacuated tube collectors in operation by economic region at the end of 2007

Figure 17: Annual collector yield of glazed flat-plate and evacuated tube collectors in operation by economic region at the end of 2007 in kWh per 1,000 inhabitants

Figure 18: Annual collector yield of unglazed collectors in operation by economic region at the end of 2007

Figure 19: Annual collector yield of unglazed collectors in operation by economic region at the end of 2007 in kWh per 1,000 inhabitants

Figure 20: Annual energy savings in oil equivalent by glazed flat-plate and evacuated tube collectors by economic region at the end of 2006

Figure 21: Annual energy savings in oil equivalent by glazed flat-plate and evacuated tube collectors in operation by economic region at the end of 2007 per 1,000 inhabitants

Figure 22: Annual energy savings in oil equivalent by unglazed collectors by economic region at the end of 2007

Figure 23: Annual energy savings in oil equivalent by unglazed collectors by economic region at the end of 2007 per 1,000 inhabitants

Figure 24: Annual contribution to $\mathrm{CO}_{2}$ reduction by flat-plate and evacuated tube collectors by economic region the end of 2006

Figure 25: Annual contribution to $\mathrm{CO}_{2}$ reduction by flat-plate and evacuated tube collectors by economic region at the end of 2007 per 1,000 inhabitants

Figure 26: Annual contribution to $\mathrm{CO}_{2}$ reduction by unglazed collectors by economic region at the end of 2007

Figure 27: Annual contribution to $\mathrm{CO}_{2}$ reduction by unglazed collectors by economic region at the end of 2007 per 1,000 inhabitants 
Figure 28: Distribution of different applications by economic region for the total capacity in operation of glazed and evacuated tube collectors

Figure 29: Distribution of different applications of the world's top-10-countries related to the total capacity in operation of glazed and evacuated tube collectors in 2007

Figure 30: Distribution of different applications in the European top-10-countries related to the total capacity in operation of glazed and evacuated tube collectors in 2007

Figure 31: Large-scale solar heating and cooling plants in Europe

Figure 32: Distribution of different solar thermal applications by economic region, which were installed in the year 2007

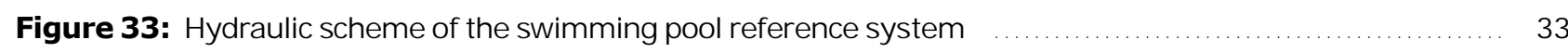

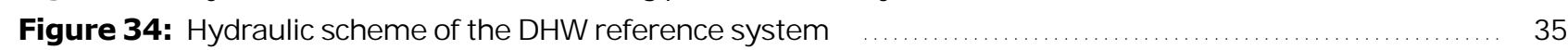

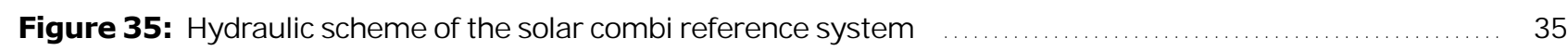

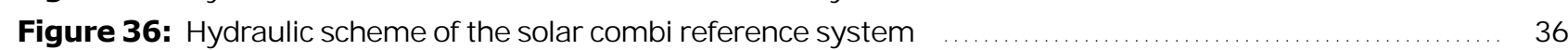

\subsection{Index of tables}

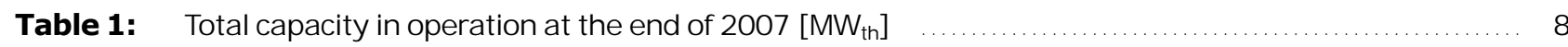

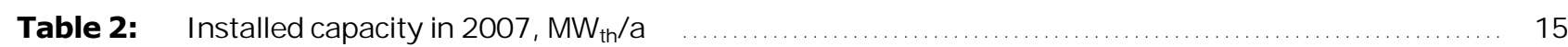

Table 3: Calculated collector yield and corresponding oil equivalent as well as $\mathrm{CO}_{2}$ reduction of all solar thermal systems (systems for hot water, space heating and swimming pool heating) at the end of 2007

Table 4: Calculated collector yield and corresponding oil equivalent as well as $\mathrm{CO}_{2}$ reduction of solar thermal systems for hot water preparation and space heating with flat-plate and evacuated tube collectors at the end of 2007

Table 5: Calculated collector yield and corresponding oil equivalent as well as $\mathrm{CO}_{2}$ reduction of solar thermal systems for swimming pool heating with unglazed collectors at the end of 2007

Table 6: Reference systems for swimming pool systems

Table 7: Reference systems for domestic hot water systems for single family houses and the percentage of the total collector area in operation (flat-plate and evacuated tube collectors)

Table 8: Reference systems for domestic hot water systems for multi-family houses, hotels and district heating and the percentage of the total collector area in operation (flat-plate and evacuated tube collectors)

Table 9: Reference systems for combisystems for single-family houses and the percentage of the total collector area in operation (flat-plate and evacuated tube collectors)

Table 10: Inhabitants of the 49 surveyed countries in alphabetic order

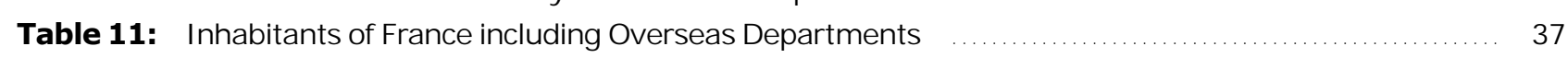

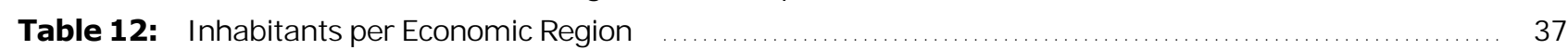

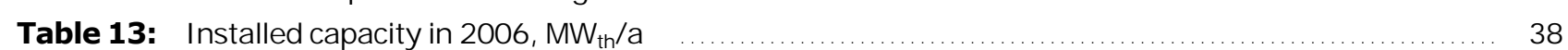

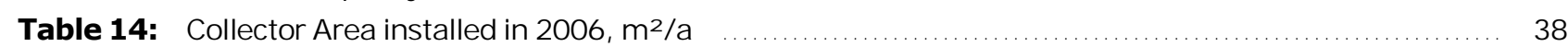

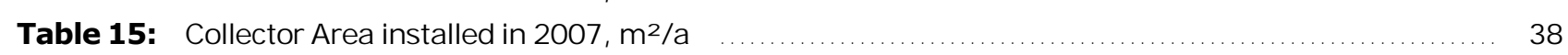

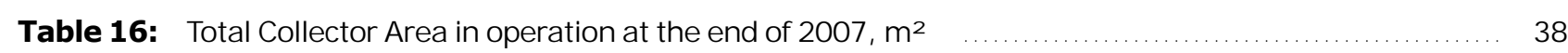

